This report was prepared as an account of work sponsored by an agency of the United States Government. Neither the United States Government nor any agency thereof, nor any of their employees, makes any warranty, express or implied, or assumes any legal liability or responsibility for the accuracy, completeness, or usefulness of any information, apparatus, product, or process disclosed, or represents that its use would not infringe privately owned rights. Reference herein to any specific commercial product, process, or service by trade name, trademark, manufacturer, or otherwise does not necessarily constitute or imply its endorsement, recommendation, or favoring by the United States Government or any agency thereof. The views and opinions of authors expressed herein do not necessarily state or reflect those of the United States Government or any agency thereof.

\title{
A Chemical Basis for the Partitioning of Radionuclides in Incinerator Operation
}

\author{
L. L. Burger
}

January 1995

Prepared for the U.S. Department of Energy under Contract DE-AC06-76RLO 1830

Pacific Northwest Laboratory

Operated for the U.S. Department of Energy

by Battelle Memorial Institute

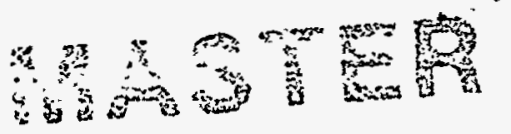




\title{
DISCLAIMER
}

This report was prepared as an account of work sponsored by an agency of the United States Government. Neither the United States Government nor any agency thereof, nor Battelle Memorial Institute, nor any of their employees, makes any warranty, expressed or implied, or assumes any legal liability or responsibility for the accuracy, completeness, or usefulness of any information, apparatus, product, or process disclosed, or represents that its use would not infringe privately owned rights. Reference herein to any specific commercial product, process, or service by trade name, trademark, manufacturer, or otherwise does not necessarily constitute or imply its endorsement, recommendation, or favoring by the United States Government or any agency thereof, or Battelle Memorial Institute. The views and opinions of authors expressed herein do not necessarily state or reflect those of the United States Government or any agency thereof.

\author{
PACIFIC NORTHWEST LABORATORY \\ operated by \\ BATTELLE MEMORIAL INSTITUTE \\ for the \\ UNITED STATES DEPARTMENT OF ENERGY \\ under Contract DE-AC06-76RLO 1830
}

Printed in the United States of America

Available to DOE and DOE contractors from the

Office of Scientific and Technical Information, P.O. Box 62, Oak Ridge, TN 37831;

prices available from (615) 576-8401. FTS 626-8401.

Available to the public from the National Technical Information Service,

U.S. Department of Commerce, 5285 Port Royal Rd., Springfield, VA 22161. 


\section{DISCLAIMER}

Portions of this document may be illegible in electronic image products. Images are produced from the best available original document. 
PNL-10364

UC -601

A CHEMICAL BASIS FOR THE PARTITIONING OF RADIONUCLIDES IN INCINERATOR OPERATION

L. L. Burger

January $1995^{\circ}$

Prepared for

the U.S. Department of Energy

under Contract DE-AC06-76RLO 1830

Pacific Northwest Laboratory

Richland, Washington 99352 


\section{$-$}

. 


\section{ABSTRACT}

Incineration as a method of treating radioactive or mixed waste is attractive because of volume reduction, but may result in high concentrations of some hazardous components. For safety reasons during operation, and because of the environmental impact of the plant, it is important to know how these materials partition between the furnace slay, the flay ash, and the stack emission. The chemistry of about 50 elements is discussed and through consideration of high temperature thermodynamic equilibria, an attempt is made to provide a basis for predicting how various radionuclides and heavy metals behave in a typical incinerator. The chemistry of the individual elements is first considered and a prediction of the most stable chemical species in the typical incinerator atmosphere is made. The treatment emphasizes volatility and the parameters considered are temperature, acidity, oxygen, sulfur, and halogen content, and the presence of several other key non-radioactive elements. A computer model is used to calculate equilibrium concentrations of many species in several systems at temperatures ranging from 500 to $1600^{\circ} \mathrm{K}$. It is suggested that deliberate addition of various feed chemicals can have a major impact on the fate of many radionuclides and heavy metals. Several problems concerning limitations and application of the data are considered. 


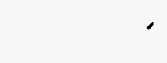

$\cdot$ 


\section{ACKNOWLEDGMENTS}

The author would like to acknowledge the editing help of Don Hanley and many helpful technical discussions with Rosanne Aaberg and Larry Pederson, all of Pacific Northwest Laboratory. 


\section{CONTENTS}

ABSTRACT ...............................

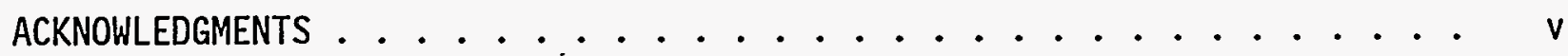

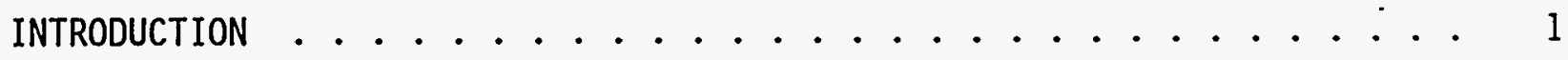

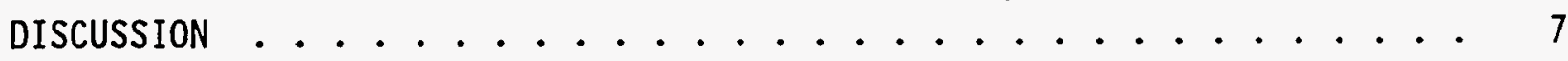

GENERAL CONSIDERATIONS ................. 7

THE ACIDIC GASES ....................... 14

GROUPS IA AND IIA ELEMENTS ............... 26

TRANSITION ELEMENTS AND GROUP IIB .............. 27

GROUPS IIIA AND IVA ELEMENTS .................. 29

LANTHANIDE AND ACTINIDE ELEMENTS . . . . . . . . . 30

COMPLEX EQUILIBRIA MODEL CALCULATIONS ........... 30

PARTITIONING OF THE ELEMENTS ................ 55

OTHER INCINERATOR MODIFICATIONS ................ 61

THE CONTROLLED AIR INCINERATOR ............ 61

THE CEMENT KILN .................... 61

EFFICIENCY OF AQUEOUS SCRUBS .............. 62

DELIBERATE ADDITIONS TO THE FEED ............ 62

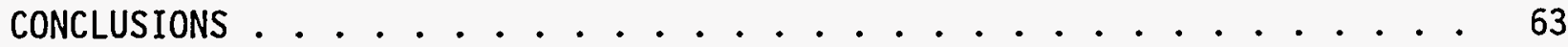

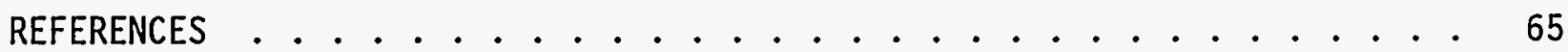




\section{FIGURES}

1 Simplified Schematic Diagram of an Incinerator........ 5

2 Vapor Pressures of Metals, Metal 0xides and Hydroxides, and Metal Halides at $1000 \mathrm{~K}$.............. 12

3 Calculated Free Energies of Reaction, as a Function of Temperature ( $500 \mathrm{~K}$ to $1500 \mathrm{~K}$ ), for Metal 0xides Forming Chlorides: $\mathrm{Co}, \mathrm{Cu}, \mathrm{Zn}, \mathrm{Cd}$, and $\mathrm{Pb} \ldots \ldots 19$

$4 \quad$ Calculated Free Energies of Reaction, as a Function of Temperature ( $500 \mathrm{~K}$ to $1500 \mathrm{~K}$ ), for Metal 0xides Forming Chlorides: $\mathrm{Cr}, \mathrm{Mn}, \mathrm{Fe}, \mathrm{Ni}$, and $\mathrm{Hg} \ldots \ldots 20$

$5 \quad$ Calculated Free Energies of Reaction, as a Function of Temperature ( $500 \mathrm{~K}$ to $1750 \mathrm{~K}$ ), for Metal 0xides Forming Chlorides: $\mathrm{Na}, \mathrm{Cs}, \mathrm{Be}, \mathrm{Ca}, \mathrm{Sr}, \mathrm{Ge}, \mathrm{Sn}, \mathrm{Sb}$, $\mathrm{Bi}$, Th, and $\mathrm{Pu}$

$6 \quad$ Calculated Free Energies of Reaction, as a Function of Temperature $(800 \mathrm{~K}$ to $1200 \mathrm{~K})$, for Metal Oxides Forming Sulfates: $\mathrm{Mg}, \mathrm{Mn}, \mathrm{Fe}, \mathrm{Co}, \mathrm{Ni}, \mathrm{Cu}, \mathrm{Zn}, \mathrm{Zr}$, $\mathrm{Ag}, \mathrm{Cd}, \mathrm{Sn}, \mathrm{Hg}, \mathrm{Pb}$, and $\mathrm{Pu} \ldots \ldots 23$

$7 a, b$ Calculated Equilibrium Concentrations, as a Function of Temperature, $(500 \mathrm{~K}$ to $1500 \mathrm{~K})$, in Incinerator Off-Gas for an Initial Mixture of $\mathrm{H}_{2} \mathrm{O}, \mathrm{O}_{2}, \mathrm{CO}_{2}, \mathrm{~N}_{2}$, $\mathrm{NO}_{2}, \mathrm{SO}_{2}, \mathrm{P}_{2} \mathrm{O}_{3}$, and $\mathrm{HCl}$ (Test 1 ) .............. 33

8a,b Calculated Equilibrium Concentrations, as a Function of Temperature $(500 \mathrm{~K}$ to $1500 \mathrm{~K})$, in Incinerator Off-Gas with $\mathrm{Ni}$ and $\mathrm{Na}$ Added to Initial Mixture and (a) $0.01 \mathrm{~mol} \mathrm{HCl}$ and (b) $0.05 \mathrm{~mol} \mathrm{HCl}$ in Initial Feed (Test 2)

8c,d Calculated Equilibrium Concentrations, as a Function of Temperature ( $500 \mathrm{~K}$ to $1500 \mathrm{~K})$, in Incinerator Off-Gas with $\mathrm{Ni}$ and $\mathrm{Na}$ Added to the Initial Mixture and with Increased $\mathrm{HCl}(0.05 \mathrm{~mol})$ and Reduced $\mathrm{Na}_{2} \mathrm{CO}_{3}$ (from 0.1 to $0.01 \mathrm{~mol}$ ) 
9a,b Calculated Equilibrium Concentrations, as a Function of Added $\mathrm{CuSO}_{4}$ (Test 3) in Incinerator Off-Gas: Gaseous Chlorides of $\mathrm{Na}, \mathrm{Ca}, \mathrm{Ni}, \mathrm{Cu}, \mathrm{Zn}$, and $\mathrm{Pb}$ at Temperatures (a) $1000 \mathrm{~K}$ and (b) $1500 \mathrm{~K} \ldots \ldots$. . . . .

9c,d Calculated Equilibrium Concentrations, as a Function of Added $\mathrm{CuSO}_{4}$, of Condensed Phase Products in an Incinerator: Sulfates of $\mathrm{Na}, \mathrm{Ca}, \mathrm{Ni}, \mathrm{Cu}, \mathrm{Zn}$, and $\mathrm{Pb}$ at Temperatures

(c) $1000 \mathrm{~K}$ and

(d) $1500 \mathrm{~K}$

10a,b Calculated Equilibrium Concentrations, as a Function of Added $\mathrm{CaCl}_{2}$ (Test 4), in Incinerator Off-Gas: Gaseous Chlorides of $\mathrm{Cs}, \mathrm{Ca}, \mathrm{Ni}, \mathrm{Cu}, \mathrm{Zn}$, and $\mathrm{Pb}$ at Temperatures (a) $1100 \mathrm{~K}$ and (b) $1500 \mathrm{~K} \ldots . . . . .38$

10c,d Calculated Equilibrium Concentrations, as a Function of Added $\mathrm{CaCl}_{2}$, of Condensed Phase Products in an Incinerator: Oxides of $\mathrm{Ca}, \mathrm{Ni}, \mathrm{Cu}, \mathrm{Zn}$, and $\mathrm{Pb}$ at Temperatures at (c) $1100 \mathrm{~K}$ and (d) $1500 \mathrm{~K}$.......... 39

10e, $f$ Calculated Equilibrium Concentrations, as a Function of Added $\mathrm{CaCl}_{2}$, of Condensed Phase Products in an Incinerator: Sulfates of $\mathrm{Cs}, \mathrm{Ca}, \mathrm{Ni}, \mathrm{Cu}, \mathrm{Zn}$, and $\mathrm{Pb}$ at Temperatures (e) $1000 \mathrm{~K}$ and (f) $1500 \mathrm{~K}$......... 40

11a,b Calculated Equilibrium Concentrations, as a Function of Temperature ( $700 \mathrm{~K}$ to $1700 \mathrm{~K}$ ), in Incinerator Off-Gas of (a) S, N, and C Oxides and Acid Gases and (b) Chlorides and Fluorides of $\mathrm{Cs}, \mathrm{Na}$, and $\mathrm{Cu}$ (Test 5) .... . 41

.11c,d Calcúlated Equilibrium Concentrations, as a Function of Temperature ( $700 \mathrm{~K}$ to $1700 \mathrm{~K}$ ), in Incinerator Off-Gas (Test 5) of (c) Chlorides, Fluorides, and Hydroxides of $\mathrm{Na}, \mathrm{Cs}, \mathrm{Ca}, \mathrm{Mn}, \mathrm{Fe}, \mathrm{Co}$, and $\mathrm{Zn}$ and (d) Condensed Phase Chlorides of $\mathrm{Na}, \mathrm{Cs}, \mathrm{Ca}, \mathrm{Mn}, \mathrm{Fe}, \mathrm{Co}, \mathrm{Cu}$, and $\mathrm{Zn} \ldots . .$.

lle,f Calculated Equilibrium Concentrations, as a Function of Temperature ( $700 \mathrm{~K}$ to $1700 \mathrm{~K}$ ) in an Incinerator (Test 5) of (e) Condensed Phase Fluorides of $\mathrm{Na}, \mathrm{Cs}$, $\mathrm{Ca}, \mathrm{Mn}, \mathrm{Fe}, \mathrm{Co}, \mathrm{Cu}$, and $\mathrm{Zn}$ and ( $f$ ) Condensed Phase Sulfates of $\mathrm{Na}, \mathrm{Cs}, \mathrm{Ca}, \mathrm{Mn}, \mathrm{Co}$, and $\mathrm{Zn} \ldots \ldots$ 
llg, h Calculated Equilibrium Concentrations, as a Function of Temperature ( $700 \mathrm{~K}$ to $1700 \mathrm{~K})$, in Incinerator Off-Gas (Test 5) of (g) Condensed Phase 0xides of $\mathrm{Ca}, \mathrm{Mn}, \mathrm{Fe}, \mathrm{Co}, \mathrm{Cu}$, and $\mathrm{Zn}$ and $(\mathrm{h})$. Condensed Phase Carbonates of $\mathrm{Na}, \mathrm{Cs}, \mathrm{Ca}, \mathrm{Mn}, \mathrm{Fe}, \mathrm{Co}, \mathrm{Cu}$, and $\mathrm{Zn} \ldots . .$.

12a,b Calculated Equilibrium Concentrations, as a Function of $\mathrm{HCl}$ Feed, in Incinerator Off-Gas at Temperature $1500 \mathrm{~K}$ (Test 6), Showing the HCl Effect on Volatility of (a) Chlorides of $\mathrm{Na}, \mathrm{Cs}, \mathrm{Ca}, \mathrm{Mn}, \mathrm{Co}, \mathrm{Cu}, \mathrm{Zn}$, and $\mathrm{Pb}$ and (b) Fluorides, Chlorides, and Hydroxides of $\mathrm{Na}$, Cs, $\mathrm{Fe}$, and $\mathrm{Sn} \ldots \ldots \ldots \ldots . \ldots . \ldots . \ldots 45$

13a,b Calculated Equilibrium Concentrations, as a Function of $\mathrm{HCl}$ Feed, in Incinerator Off-Gas (Test 7), Showing the $\mathrm{HCl}$ Effect on Volatility of $\mathrm{Na}, \mathrm{Cs}, \mathrm{Co}, \mathrm{Zn}$, and $\mathrm{Sb}$ at Temperatures (a) $1000 \mathrm{~K}$ and (b) $1500 \mathrm{~K} \ldots \ldots$. . . . .

13c,d Calculated Equilibrium Concentrations, as a Function of HCl Feed, in Condensed Phase Products in an Incinerator (Test 7), Showing the Effect of $\mathrm{HCl}$ Concentration on Metal Oxides and Salts at $1000 \mathrm{~K}$ for (c) Cs, Ca, Sr, Co, $\mathrm{Zn}, \mathrm{Zr}$, and $\mathrm{Sb}$; and (d) $\mathrm{Na}, \mathrm{Ca}, \mathrm{Sr}, \mathrm{Zn} \ldots \ldots$

13e,f Calculated Equilibrium Concentrations, as a Function of HCl Feed, in Condensed Phase Products in an Incinerator (Test 7), Showing the Effect of $\mathrm{HCl}$ Concentration on Metal Vaporization at $1000 \mathrm{~K}$ for (e) $\mathrm{Na}, \mathrm{Ca}, \mathrm{Sr}, \mathrm{Co}, \mathrm{Zn}$, and $\mathrm{Sb}$; and $(\mathrm{f}) \mathrm{Na}, \mathrm{Cs}, \mathrm{Ca}, \mathrm{Co}, \mathrm{Zr}$, and $\mathrm{Sb} \ldots \ldots \ldots$ 


\section{TABLES}

$1 \quad$ Elements for Partitioning Evaluation Indicated in Bold Type, with Position on the Periodic Table of the Elements Shown . . . . . . . . . . . . . . . 4

2 Reference Composition of Combustion Off-gas . . . . . . . . . 7

3 Calculated Equilibrium Vapor Pressures of Some Stable Metal Halides Pressures in atm . . . . . . . . . . . . . 9

4 Boiling Points and Vapor Pressures of Metals Pressure in atm . . . . . . . . . . . . . . . . 10

5 Boiling Points and Vapor Pressures of 0xides and Hydroxides :....................... 11

6 Free Energies of Formation of Important Metal Salts and 0xides ..................... . . 13

7 Approximate Temperatures Giving Vapor Pressures Equal to that of $\mathrm{Hg}$ at $298 \mathrm{~K}, 2.4 \mathrm{E}-06 \mathrm{~atm}$. . . . . . . . . . . . . 29

8 Feed Compositions used for HSC Tests . . . . . . . . . . . . 32

9 Amounts of Metal Compounds Present During $\mathrm{CaCl}_{2}$ Additions, Test 4 ................... 51

10 Most Likely Compounds in the Oxidizing Incinerator . . . . . . . 56

11 Estimated Partition Values . . . . . . . . . . . . . 57

12 Estimated Partition of Selected Nuclides

Temperature $1500 \mathrm{~K}$. . . . . . . . . . . . . . . . 58 


\section{INTRODUCTION}

For waste containing smal1 amounts of radioactivity, rad waste (RW), or mixed waste (MW) containing both radioactive and hazardous wastes (HW), incineration is a logical management candidate because of inherent safety, waste volume reduction, and low costs. However, the large decrease in waste volume achieved by incineration also results in a higher concentration of most of the radionuclides and nonradioactive heavy metals in the ash products. These concentrations impact subsequent treatment and disposal. The various constituents (chemical elements) are not equal in concentration in the various incinerator feed materials, nor are they equal in their contribution to health risks on subsequent handling, or accidental release. Thus, for management of the wastes it is important to know how the nuclides may partition among the primary combustion residues, which may be either an ash or a fused slag; the fine particulates or fly ash that is carried in the burner off-gas and trapped by several different techniques; and/or a final airborne fraction that escapes to the atmosphere.

The objective of this report is to provide an estimate of how different elements of concern may behave in the chemical environment of the incinerator. The study examines the properties of the elements of concern, and employs thermodynamic calculations, to help predict the fate of these RW and MW constituents. Some comparisons are made with reported element behavior.

Many types and configurations of incinerators have been designed and tested (SAI Corp 1991, Travis and Cook 1989, Steverson 1991). The most common employ ordinary air combustion, usually in a two-stage burner. The primary stage operates at about 800 to $1000^{\circ} \mathrm{C}$ ( 1073 to $1273 \mathrm{~K}$ ) and may or may not be oxygen deficient. The second stage is oxidizing, which employs a higher temperature, often 1200 to $1400^{\circ} \mathrm{C}$. For a typical device, the off-gas, which contains volatile species as well as particulates, flows to a water quencher and a venturi scrubber or perhaps a cyclone separator. The filter stages that follow may be very simple, such as having the waste stream flow through a bag 
filter, or very sophisticated, such as using a series of treatment steps, combining filters, aqueous scrubbers, and electrostatic devices. HEPA filters. are occasionally included. Several combinations of these air polution control devices (APCD) are discussed by Chao (1988).

Of $23 \mathrm{HW}$ incinerators surveyed by Sedman and Esparza (1991), three included HEPA filters as part of the system, seven had no off-gas treatment, and the remaining had various assortments of liquid scrubbers and filters. A decade earlier, a survey found that more than half of the HW incinerators had no air pollution control systems (Opelt 1986).

Rad waste (RW) has been incinerated at nuclear sites for over 40 years. Perkins (1976) gave considerable detail about 50 RW incinerators in use by that date, worldwide. The requirements, along with facility descriptions of incinerators for both low-level and intermediate-level wastes, were described in a recent DOE publication (DOE 1979). Medical incinerators for RW are usually smaller and normally handle only a few short-lived radioisotopes, but they do provide additional data. An example is The University of North Carolina Environmental Control Products incinerator, which was tested with radioactive microspheres (Emery and Watson 1990).

Kyle and Bellinger (1988) compiled a literature review of radioactive partitioning in incinerators of low-level waste with emphasis on institutional waste sources. Of the 17 references, 11 contained partitioning data.

The feeds for RW amd MW incinerators may be quite different from each other, and more different yet from wastes burned in an industrial or municipal incinerator. Thus, we may expect the chemical reactions and the products to vary considerably.

Finally, coal-fired power stations and cement kilns provide different dimensions with respect to operating temperatures, feeds, and products. Cement kilns (Mantus 1992), for example, employ a long residence time, a high temperature, and in addition, operate with an alkaline environment, iristead 
of the acid environment characteristic of $\mathrm{HW}$ or $\mathrm{RW}$ incinerators which normally burn chlorinated and other acid-forming materials

The elements, including the radionuclides, that are of interest in this study are 1isted in Table 1. Some are a radiation hazard, some a chemical hazard; others are included because their chemistry is significant in incinerator operation. A typical incinerator is shown in Figure 1 in simplified form.

Radionuclides and other elements of concern can be carried from the combustion zone as particulate matter. The formation of volatile species is a second mechanism. Condensation as the gases cool may produce either new particulates or aerosols. More frequently, however, they adsorb on existing fiy-ash particles. The fly-ash may cover a range of particle sizes from less than one $\mu \mathrm{m}$ to several $\mathrm{mm}$.

Unti1 recently the emphasis with regard to $\mathrm{HW}$ has been on the destruction and removal of toxic organic materials. However, Waterland et a1. (1991) point out that with otherwise properly operated incinerators, the trace metal emissions may pose the largest risk to human health and the environment. Also, the control of solids, i.e., particulate emissions, has been historically one of the most difficult problems (Steverson 1991). Although many nonmetals are included in Table 1, the metals receive the major emphasis of the present paper.

Several investigators have examined the chemistry of the elements of concern as the waste products move through the incinerator system. Greenberg, Zoller, and Gordon (1978) pointed out the possible significance of HCl in incinerator gases and the appreciable volatility of metal halides. Trichon and Feldman (1988) again noted the importance of the metal oxide/metal halide equilibria and noted that different regions of the combustion chamber could show different behavior. Fernandez et al. (1992) recently considered the role 
TABLE 1. Elements for Partitioning Evaluation Indicated in Bold Type, with Position on the Periodic Table of the Elements Shown

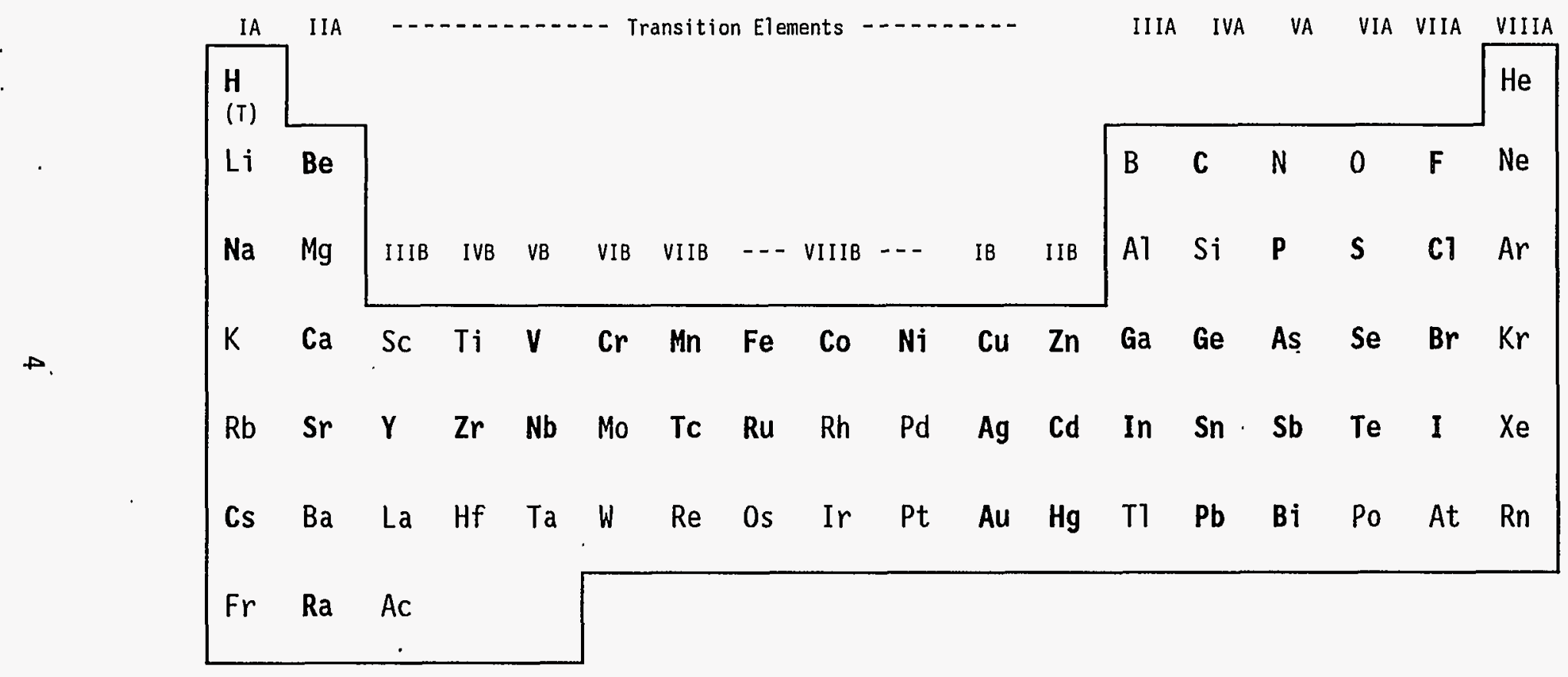

$\begin{array}{llllllllllllll}\text { Ce } & \mathrm{Pr} & \mathrm{Nd} & \mathrm{Pm} & \mathrm{Sm} & \mathrm{Eu} & \mathrm{Gd} & \mathrm{Tb} & \mathrm{Dy} & \mathrm{Ho} & \mathrm{Er} & \mathrm{Tm} & \mathrm{Yb} & \mathrm{Lu} \\ \mathrm{Th} & \mathrm{Pa} & \mathrm{U} & \mathrm{Np} & \mathrm{Pu} & \mathrm{Am} & \mathrm{Cm} & \mathrm{Bk} & \mathrm{Cf} & \mathrm{Es} & \mathrm{Fm} & \mathrm{Md} & \text { No } & \mathrm{Lr}\end{array}$




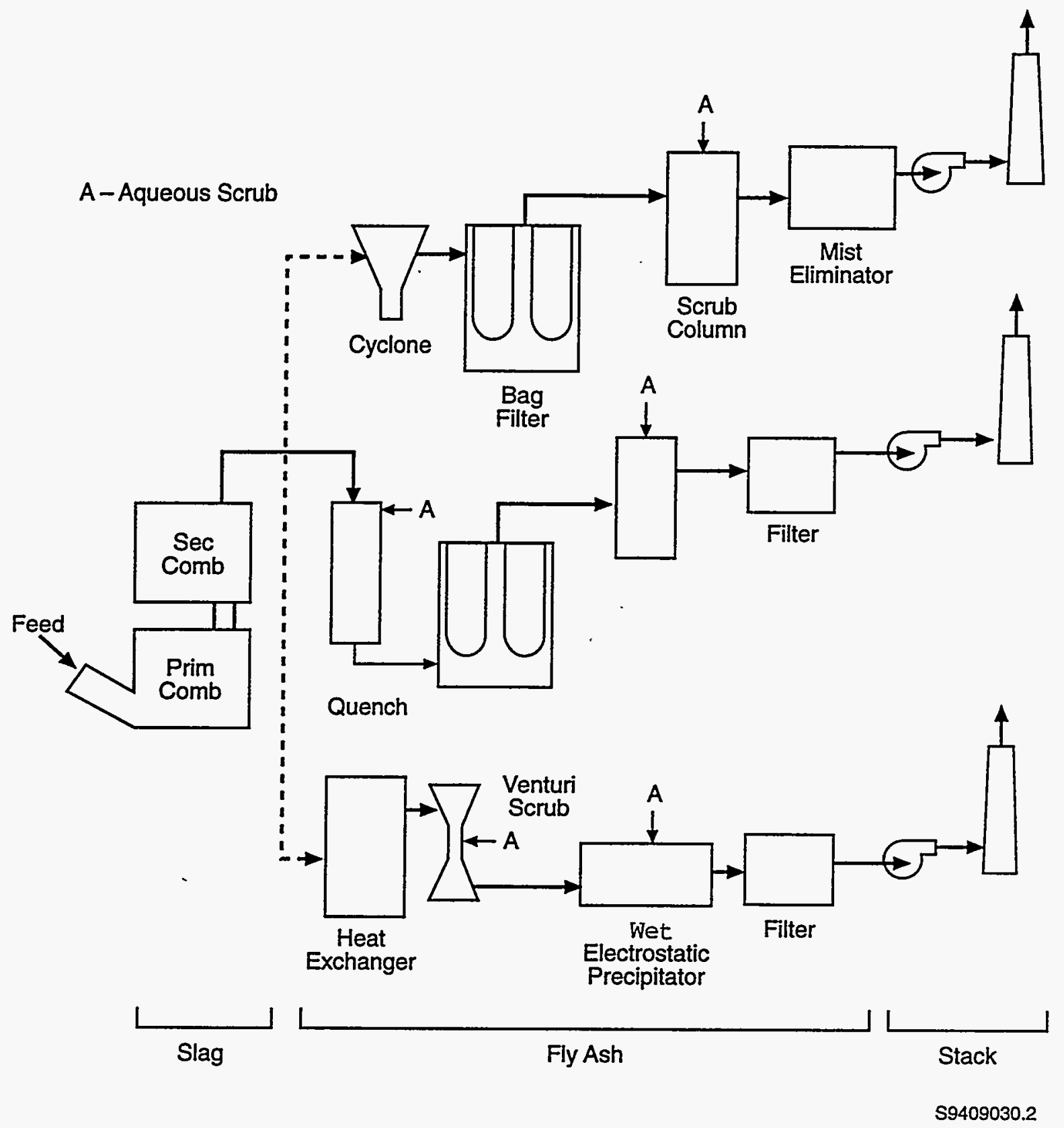

FIGURE 1. Simp1ified Schematic Diagram of an Incinerator 
of halogen reactions in more detail and calculated free energies for several metals for the reaction metal plus $\mathrm{O}_{2}$ plus $\mathrm{HCl}$. The possible role of other anionic species seems to have received little attention in incinerator studies. 


\section{DISCUSSION}

For some of the elements in Table 1 we may expect the elemental form to be stable and volatile; for some it is the halides, and for others, the oxides or hydroxides. Although several metals may be in elemental vapor form during the high-temperature destruction process, removal in the off-gas system more Tikely becomes a problem of trapping metal-containing solids or gases such as oxides or halides. In turn, this introduces the questions of the chemical stability of the several compounds as well as their vapor pressures and water solubilities. Thus, it becomes important to examine the nature of the chemical species that may form in the incinerator as well as the equilibria that may exist among them. Reference data are primarily from the National Bureau of Standards (Wagman 1982, Barin 1989, and Outokumpu Research 1994). Additional data come from Glassner (1958), Ephraigm (1967), Bailar (1973), Dean (1993), and Weast (1976).

\section{GENERAL CONSIDERATIONS}

Combustion of typical wastes in an excess of air will result in a gas mixture approximating the composition of Table 2.

TABLE 2. Reference Composition of Combustion Off-gas

\begin{tabular}{lc}
\hline \multicolumn{1}{c}{ Gas } & Mole Percent \\
\hline $\mathrm{H}_{2} \mathrm{O}$ & $15-25$ \\
$\mathrm{O}_{2}$ & $6-12$ \\
$\mathrm{CO}_{2}$ & $6-10$ \\
$\mathrm{CO}$ & trace \\
$\mathrm{HCl}, \mathrm{HF}$ & $0.1-5$ \\
$\mathrm{NO}$ & $\sim 1$ \\
$\mathrm{SO}_{\mathrm{x}}$ & $\sim 2$ \\
$\mathrm{PO}_{\mathrm{x}}$ & $\sim 1$ \\
$\mathrm{~N}_{2}$ & Remainder \\
\hline
\end{tabular}


The system as defined by Table 2 is oxidizing, and is acidic. However, the slag or residue after the volatile gases have been driven off could become alkaline, depending on the ratios of the bulk constituent elements. Thus, many metals could remain in the ash as silicates, borates, arsenates, etc. Elements that might be in the metallic state include $\mathrm{Au}, \mathrm{Hg}$, and $\mathrm{Ag}$, at least in the absence of halogens. Under special conditions, other elements can be reduced to the metallic state.

Because vapor pressures will be especially important, Tables 3, 4, and 5 give data for several important metals, plus their halides and oxides arranged in decending order of their volatility, in the temperature range of interest. Several oxyhalides, such as $\mathrm{CrO}_{2} \mathrm{Cl}_{2}$, are also very volatile.

The very large range of vapor pressures is best seen in Figure 2 which presents the $1000 \mathrm{~K}$ data.

However, the most volatile compound of an element is often not the most stable. For example, the compounds $\mathrm{SnCl}_{2}$ and $\mathrm{InCl}_{3}$ are very volatile but in the $\mathrm{O}_{2}-\mathrm{H}_{2} \mathrm{O}$ atmosphere the former would be converted to $\mathrm{SnO}_{2}$, while the latter would form $\mathrm{In}_{2} \mathrm{O}_{3}$, or $\mathrm{InF}_{3}$; these are all nonvolatile. Thus, the free energies of formation of the various compounds are important, but more significant are the free energies as a function of temperature of the actual reactions that may occur. Table 6 compares some $\Delta G$ formation data for various salts and oxides at $1000 \mathrm{~K}$. Several very volatile halides, such as $\mathrm{ZrCl}_{4}$ and $\mathrm{TiCl}_{4}, \mathrm{like}_{\mathrm{k}}$ those of $\mathrm{Sn}$ and In are unstable in the presence of oxygen and water and are not included in the table. 
TABLE 3. Calculated Equilibrium Vapor Pressures of Some Stable Metal Halides Pressures in atm

\begin{tabular}{|c|c|c|}
\hline Gaseous Form & $\mathrm{P}, 1000 \mathrm{~K}$ & $\mathrm{P}, 1500 \mathrm{~K}$ \\
\hline $\begin{array}{l}\mathrm{HgCl}_{2} \\
\mathrm{SbCl}]_{3} \\
\mathrm{BiCl}_{3} \\
\mathrm{SnCl}_{2} \\
\mathrm{FeCl}_{3}\end{array}$ & $\begin{array}{l}9.7 E+01 \\
7.96 E+01 \\
2.79 E+01 \\
2.19 \\
2.05\end{array}$ & $\begin{array}{c}(3.66 E+02)^{(a)} \\
1.38 E+02 \\
1.96 E+02 \\
3.67 E+01 \\
2.38 E+01\end{array}$ \\
\hline $\begin{array}{l}\mathrm{ZnCl}_{2} \\
\mathrm{PbCl}_{2} \\
\mathrm{CoCl}_{2} \\
\mathrm{NiCl}_{2} \\
\mathrm{CdCl}_{2}\end{array}$ & $\begin{array}{c}9.31 \mathrm{E}-01 \\
5.31 \mathrm{E}-02 \\
8.13 \mathrm{E}-03 \\
3.41 \mathrm{E}-03 \\
(3.05 \mathrm{E}-03)\end{array}$ & $\begin{array}{l}7.93 E+01 \\
8.72 \\
3.55 \\
2.96 E+01 \\
(8.7)\end{array}$ \\
\hline $\begin{array}{l}\mathrm{FeCl}_{2} \\
\mathrm{MnCl}_{2} \\
\mathrm{CsF} \\
\mathrm{CsI} \\
\mathrm{Hg}_{2} \mathrm{Cl}_{2}\end{array}$ & $\begin{array}{l}3.03 E-02 \\
1.74 E-03 \\
1.66 E-03 \\
1.48 E-03 \\
1.04 E-03\end{array}$ & $\begin{array}{l}5.12 \\
9.69 \mathrm{E}-01 \\
7.9 \mathrm{E}-01 \\
5.5 \mathrm{E}-01 \\
2.24\end{array}$ \\
\hline $\begin{array}{l}\mathrm{CsCl} \\
\mathrm{Cs}_{2} \mathrm{Cl}_{2} \\
\mathrm{NaCl}_{2} \\
\mathrm{AgCl} \\
\mathrm{Na}_{2} \mathrm{Cl}_{2}\end{array}$ & $\begin{array}{l}7.02 \mathrm{E}-04 \\
3.57 \mathrm{E}-04 \\
6.02 \mathrm{E}-05 \\
3.55 \mathrm{E}-05 \\
2.2 \mathrm{E}-05\end{array}$ & $\begin{array}{l}3.94 \mathrm{E}-01 \\
1.10 \mathrm{E}-01 \\
1.11 \mathrm{E}-01 \\
6.24 \mathrm{E}-02 \\
2.9 \mathrm{E}-02\end{array}$ \\
\hline $\begin{array}{l}\mathrm{CuCl} \\
\mathrm{NaF} \\
\mathrm{CaCl}_{2} \\
\mathrm{SrCl}_{2} \\
\end{array}$ & $\begin{array}{l}1.39 E-05 \\
1.3 E-07 \\
2.19 E-08 \\
2.03 E-09 \\
\end{array}$ & $\begin{array}{l}3.61 \mathrm{E}-02 \\
2.9 \mathrm{E}-03 \\
1.58 \mathrm{E}-03 \\
5.86 \mathrm{E}-04 \\
\end{array}$ \\
\hline
\end{tabular}

(a) Estimated quantities in parentheses. 


\section{TABLE 4. Boiling Points and Vapar Pressures of Metals Pressure in atm}

\begin{tabular}{|c|c|c|c|c|}
\hline $\begin{array}{l}\text { Metal } \\
\text { Vapor }\end{array}$ & $\begin{array}{l}\text { Boiling } \\
\text { Point, K }\end{array}$ & & $P, 1000 \mathrm{~K}$ & P. $1500 \mathrm{~K}$ \\
\hline \multirow[t]{3}{*}{$\mathrm{Se}$} & 598 & $\mathrm{Se}_{2}$ & 1.30 & (82) \\
\hline & & $\mathrm{Se}$ & $1.52 \mathrm{E}-06$ & $9.94 \mathrm{E}-03$ \\
\hline & & $\mathrm{Se}_{2}$ & 1.30 & $8.15 E+01$ \\
\hline $\mathrm{Hg}$ & .630 & & & \\
\hline $\mathrm{As}_{4}$ & 888 sub & & & \\
\hline \multirow[t]{2}{*}{ Cs } & 948 & & 1.69 & $(50.8)$ \\
\hline & & $\mathrm{Cs}_{2}$ & $7.18 \mathrm{E}-02$ & $1.01 \mathrm{E}-02$ \\
\hline \multirow[t]{2}{*}{ K } & 1038 & & $6.92 \mathrm{E}-01$ & 15.5 \\
\hline & & $k_{2}$ & $3.55 E-02$ & 2.11 \\
\hline $\mathrm{Cd}$ & 1039 & & $6.41 E-01$ & 34.3 \\
\hline \multirow[t]{2}{*}{$\mathrm{Na}$} & 1170 & & $1.80 E-01$ & 8.64 \\
\hline & & $\mathrm{Na}_{2}$ & $2.59 \mathrm{E}-02$ & 2.42 \\
\hline $\mathrm{Zn}$ & 1179 & & $1.20 \mathrm{E}-01$ & 12.0 \\
\hline \multirow[t]{2}{*}{$\mathrm{Te}$} & 1273 & & $2.00 \mathrm{E}-05$ & $3.0 E-02$ \\
\hline & & $\mathrm{Te}_{2}$ & $4.93 \mathrm{E}-02$ & 2.57 \\
\hline $\mathrm{Sr}$ & 1685 & & $7.40 \mathrm{E}-04$ & $2.46 E-01$ \\
\hline$R a$ & $(1700)$ & & & \\
\hline $\mathrm{Ca}$ & 1755 & & $2.55 \mathrm{E}-04$ & $1.63-01$ \\
\hline$s b^{(a)}$ & 1891 & & $8.08 \mathrm{E}-04$ & $6.8 \mathrm{E}-02$ \\
\hline$B i$ & 1934 & & $2.61 E-05$ & $3.65 E-02$ \\
\hline $\mathrm{Pb}$ & 2019 & & $1.62 E-05$ & $2.49 E-02$ \\
\hline $\mathrm{Ba}$ & 2167 & & $5.01 \mathrm{E}-05$ & $2.67 E-02$ \\
\hline In & 2343 & & $9.59 \mathrm{E}-08$ & $1.20 \mathrm{E}-03$ \\
\hline Mn & 2368 & & $2.32 \mathrm{E}-08$ & $1.09 \mathrm{E}-03$ \\
\hline $\mathrm{Ag}$ & 2433 & & $6.60 \mathrm{E}-09$ & $3.64 \mathrm{E}-04$ \\
\hline Ga & 2475 & & $6.15 E-09$ & $2.51 E-04$ \\
\hline Sn & 2900 & & $8.57 E-11$ & $1.17 \mathrm{E}-05$ \\
\hline A1 & 2790 & & $5.07 E-11$ & $1.32 \mathrm{E}-05$ \\
\hline $\mathrm{Cu}$ & 2843 & & $1.56 \mathrm{E}-11$ & $9.23 \mathrm{E}-06$ \\
\hline $\mathrm{Fe}$ & 3132 & & $1.46 E-14$ & $1.50 \mathrm{E}-07$ \\
\hline $\mathrm{Ni}$ & 3200 & & $2.24 \mathrm{E}-18$ & $5.13 E-08$ \\
\hline
\end{tabular}

(a) Primarily $\mathrm{Sb}_{4}$ at $1000 \mathrm{~K}, \mathrm{Sb}_{2}$ at $1500 \mathrm{~K}$ 
TABLE 5. Boiling Points and Vapor Pressures of Oxides and Hydroxides

\begin{tabular}{|c|c|c|}
\hline Compound & Boiling Point, & $\begin{array}{l}P(\mathrm{~atm}) \\
1000 \mathrm{~K}\end{array}$ \\
\hline $\mathrm{RuO}_{4}$ & 373 & \\
\hline $\mathrm{P}_{4} \mathrm{O}_{6}$ & 446 & \\
\hline$P_{4} 0_{10}$ & $532 \operatorname{sub}^{(a)}$ & \\
\hline $\mathrm{Tc}_{2} \mathrm{O}_{7}$ & 584 & \\
\hline $\mathrm{SeO}_{2}$ & 602 sub & \\
\hline $\mathrm{TcO}_{2}$ & $(1000)$ sub & \\
\hline$A s_{2} \mathrm{O}_{3}\left(\mathrm{As}_{4} \mathrm{O}_{6}\right)$ & 738 & - \\
\hline $\mathrm{Sb}_{4} 0_{6}$ & & $1.84-02$ \\
\hline $\mathrm{CsOH}$ & 1263 & $4.14-02$ \\
\hline $\mathrm{Cs}_{2}(\mathrm{OH})_{2}$ & & $9.86-03$ \\
\hline $\mathrm{KOH}$ & & $1.16-03$ \\
\hline $\mathrm{K}_{2}(\mathrm{OH})_{2}$ & & $1.51-04$ \\
\hline $\mathrm{TeO}_{2}$ & & $1.48-04$ \\
\hline $\mathrm{NaOH}$ & 1828 & $3.72-05$ \\
\hline $\mathrm{Cs}_{2} \mathrm{O}$ & & $1.7-05$ \\
\hline $\mathrm{Na}_{2}(\mathrm{OH})_{2}$ & & $1.31-06$ \\
\hline $\mathrm{PbO}$ & & $2.6-07$ \\
\hline $\mathrm{CrO}_{3}$ & & $8.2-08$ \\
\hline
\end{tabular}

(a) Sub indicates compound sublimes 


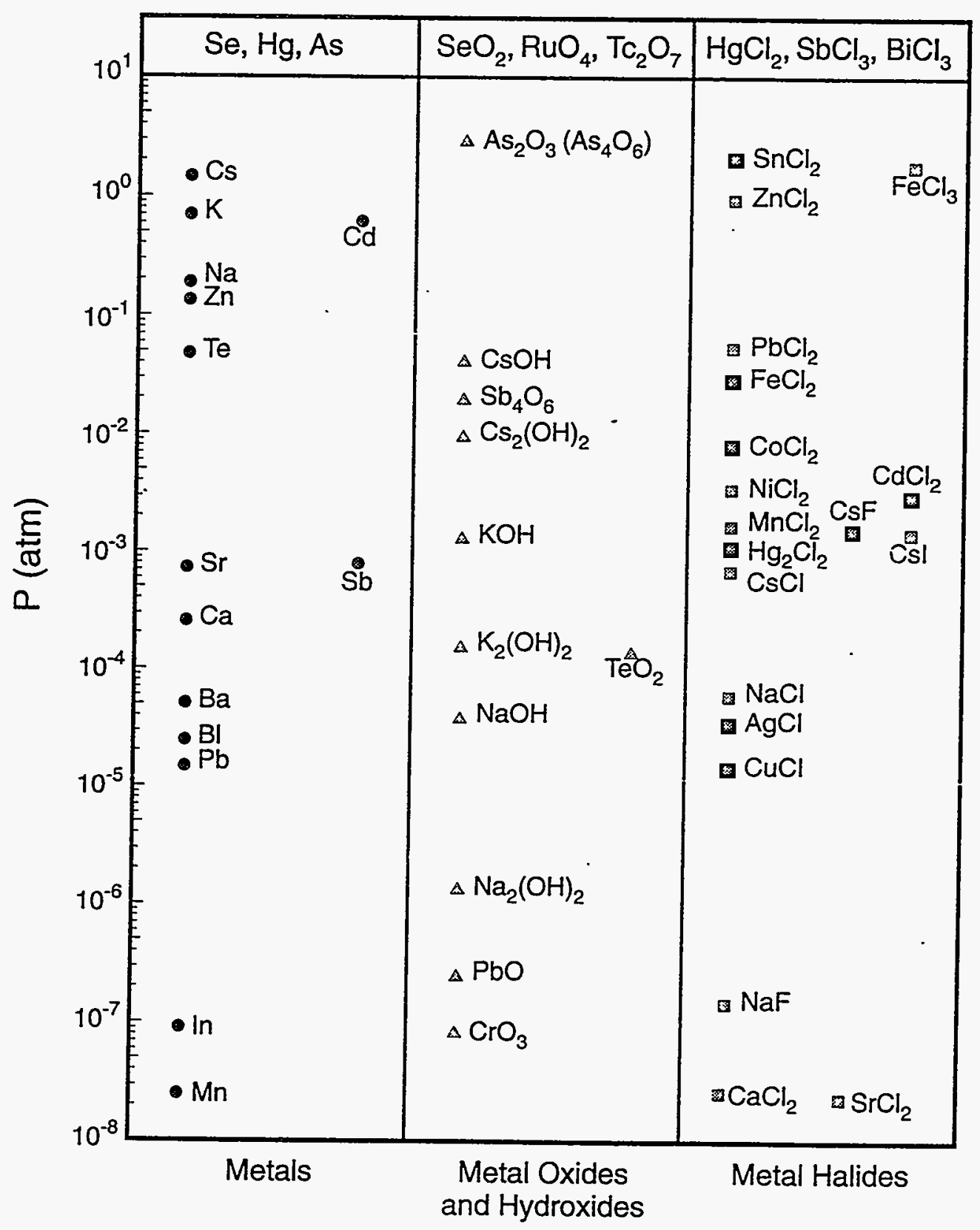

$\$ 9411007.2$

FIGURE 2. Vapor Pressures of Metals, Metal 0xides, and Hydroxides, and Metal Halides at $1000 \mathrm{~K}$ 
TABLE 6. Free Energies of Formation of Important Metal Salts and 0xides

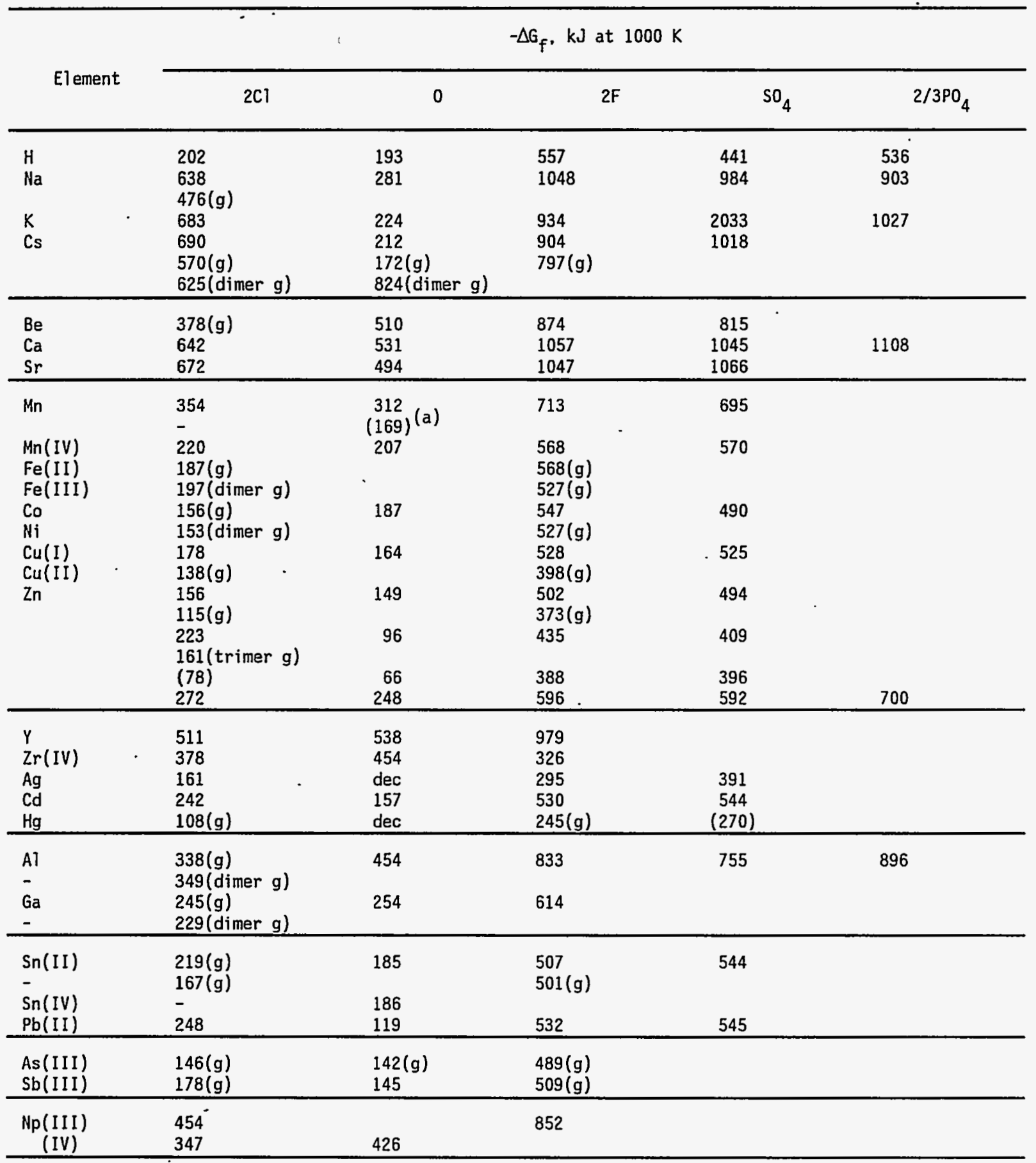

(a) Estimated quantities in parentheses. 
A few metals, such as ruthenium, have very volatile oxides (in this case $\mathrm{RuO}_{4}$ ), some of which are more stable than the halides, depending on the concentrations of water, oxygen, and halogens. Others have volatile hydroxides. For example, if the $\mathrm{H}_{2} \mathrm{O} / \mathrm{CO}_{2}$ ratio is high, $\mathrm{Cs}_{2} \mathrm{CO}_{3}$, normally stable, will convert to the hydroxide, which is volatile (Table 5).

The oxides of most of the nonmetals of interest to this study might be expected to volatilize since the acidic conditions would tend to make the anionic forms unstable. Although arsenic is usually considered a nonmetal, it and phosphorus are included in Table 5.

The significance of thermodynamic stability and chemical equilibria is illustrated using several examples. An equally important question is kinetics, the rates at which both chemical and physical reactions occur. This is seen as a much more difficult question, especially since the time intervals in the incinerator system may be very short (a few seconds in most parts of the system), and the temperature gradients are extreme.

\section{THE ACIDIC GASES}

The amounts of the acidic gases, which include $\mathrm{P}_{2} \mathrm{O}_{5}$, may vary greatly. The halogens can exist as the element or as acids, e.g., $X_{2}$ or HX. The stability of $H X$ decreases with an increase in the atomic number of $X$. For example, the reaction below:

$$
2 \mathrm{HCl}+1 / 2 \mathrm{O}_{2}(\mathrm{~g})=\mathrm{H}_{2} \mathrm{O}(\mathrm{g})+\mathrm{Cl}_{2}(\mathrm{~g})
$$

The free energies at 500,1000 , and $1500 \mathrm{~K}$ are respectively $-24.7,+8.9$, and $+43.0 \mathrm{~kJ}$. The corresponding equilibrium constants are $3.8 \mathrm{E}+02,3.4$, and 3.2E-02. For the concentrations of Table 2, about 0.01 mol fraction total $\mathrm{Cl}$, we calculate about $27 \%$ as $\mathrm{Cl}_{2}$ at $500 \mathrm{~K}, 0.2 \%$ at $1000 \mathrm{~K}$, but on7y $0.01 \%$ at $1500 \mathrm{~K}$. Reaction (1) for $\mathrm{HBr}$ gives corresponding $\Delta G$ values of $-105.2,-71.2$, and $-36.6 \mathrm{~kJ}$. Also, the $H X-X_{2}$ equilibrium ratios are concentration dependent, with the ratio $X_{2} / H X$ increasing with concentration. 
The total $\mathrm{Br}$ concentration in the incinerator is expected to be much lower than that of $\mathrm{Cl}$. At 0.01 mol\% total $\mathrm{Br}$, the element is mostly $\mathrm{Br}_{2}$ at $500 \mathrm{~K}$; about $50 \%$ at $1000 \mathrm{~K}$, and most $1 \mathrm{y} \mathrm{HBr}$ at $1500 \mathrm{~K}$. Because of the high stability of HF, no $F_{2}$ will be present. For the same reason, many metal fluorides, including those of Group I and of many of the transition metals, although normally very stable compounds, will convert to chlorides and HF in the presence of excess $\mathrm{HCl}$.

Iodine may be of special interest because of its biological significance. In contrast to the other halogens, only a trace of HI would exist at ordinary concentrations. $I_{2}$ may be the dominant species along with ICI. However, at concentrations below about $1 \mathrm{E}-04 \mathrm{~mol} \%$, and under the conditions of Table 2, equilibrium favors HI above about $1000 \mathrm{~K}$.

Nitrates and nitrites will decompose completely at the burner temperatures to $\mathrm{NO}, \mathrm{NO}_{2}$, and $\mathrm{N}_{2}$ (Stern 1972, Ephraigm 1953). Some $\mathrm{N}_{2} \mathrm{O}$ is atso expected from reduction by organic compounds. Sulfur is important because it is one of the acid gas formers. Also, because of the stability of many of the sulfate salts, it can play an important role in metal partitioning. of similar importance is phosphorus, since, like the sulfates, many metal phosphates are very stable and are nonvolatile. Carbon can exist as thermally stable Group I carbonates if other acid gases. are absent. Otherwise, ${ }^{14} \mathrm{C}$ should escape the combustion chamber as $\mathrm{CO}_{2}$ with a trace as $\mathrm{CO}$. If the system becomes sufficiently basic, other salts such as titanates and zirconates may form as nonvolatile ash components.

Volatile oxides or metal salts of volatile acidic oxides, which may be unstable at high temperatures, can, of course, re-form as the vapors cool.

As seen from Table 3, many of the metal halides are moderately volatile. As an example of important equilibria we may write for a metal M:

$$
\begin{aligned}
& M O_{x} \rightleftarrows M+x / 2 O_{2} \\
& \left.M O_{x}+2 x H C l(g) \rightleftarrows M C\right]_{2 x}+x H_{2} O
\end{aligned}
$$




$$
\mathrm{M}+2 \mathrm{xHCl}(\mathrm{g})+\mathrm{x} / 2 \mathrm{O}_{2}(\mathrm{~g}) \rightleftarrows \mathrm{MCl}_{2 \mathrm{x}}(\mathrm{g})+\mathrm{xH}_{2} \mathrm{O}(\mathrm{g})
$$

where $x$ may be a fractional as well as a whole number. $\mathrm{HF}$ or $\mathrm{HBr}$ could be substituted for $\mathrm{HCl}$ in the equations. The equilibrium constant for a reaction is

$$
K=\exp \left(-\Delta G_{f} / R T\right)
$$

where $\Delta G_{f}$ is the free energy of reaction at the temperature $T$. If $M C l_{X}$ is a gas, then for reaction (3); for example, its partial pressure, at low concentrations of $\mathrm{HCl}$, would be

$$
P_{M C l_{2}}=K(H C 1)^{2 x} /\left(H_{2} O\right)^{x}
$$

or for reaction (4)

$$
P_{\mathrm{MCl}_{2}}=K(\mathrm{HCl})^{2 x} \cdot\left(\mathrm{O}_{2}\right)^{x / 2} /\left(\mathrm{H}_{2} \mathrm{O}\right)^{x} \text {. }
$$

If $M C 1_{x}$ exists as a solid or liquid at the temperature in question, e.g., with high concentrations of $\mathrm{HCl}$, then its partial pressure is 1 imited by the free energy change for the equilibrium $M C 1(s, 1)=M C 1(g)$ and

$$
P_{\mathrm{MCl}_{2}}=\exp \left(-\Delta \mathrm{G}_{\mathrm{V}} / \mathrm{RT}\right)
$$

where $\Delta G_{v}$ is the free energy of vaporization of the halide. A similar expression would be written for the metal vapor pressure where the metal exists in its free state. $\Delta G$ data or vapor pressure tables are available for many metals and compounds, or can be estimated from boiling points plus $\Delta H_{\text {vap }}$ data. Representative data are presented in Table 4.

Many of the metals, such as iron, have several oxidation states. The free energy data indicate that at temperatures up to about $2000 \mathrm{~K}$ the most 
stable oxide of $\mathrm{Fe}$ is $\mathrm{Fe}_{2} \mathrm{O}_{3}$. The most stable iron chloride is usually $\mathrm{FeCl}_{3}$, which exists in the gas phase as both $\mathrm{FeCl}_{3}$ and $\mathrm{Fe}_{2} \mathrm{Cl}_{6}$.

In other cases, oxidation or reduction of the metal may occur. An example is copper. Since the most stable oxide is Cu0, and the most stable chloride (which also happens to be volatile) is $\mathrm{CuCl}$, the significant reactions are expected to be

$$
\mathrm{CuO}(\mathrm{s})+\mathrm{HCl}(\mathrm{g}) \rightleftarrows \mathrm{CuCl}(\mathrm{s})+1 / 2 \mathrm{H}_{2} \mathrm{O}(\mathrm{g})+1 / 4 \mathrm{O}_{2}(\mathrm{~g}),
$$

and

$$
\mathrm{CuCT}(\mathrm{s}) \rightleftarrows \mathrm{CuCl}(\mathrm{g})
$$

and similar expressions for the formation of $\mathrm{Cu}_{3} \mathrm{Cl}_{3}$, which is the more stable gaseous species. For (9), $\Delta G=-31 \mathrm{~kJ}$ at $500 \mathrm{~K}$ and $-41 \mathrm{~kJ}$ at $1000 \mathrm{~K}$. For copper, the most stable gaseous species is the trimer of $\mathrm{CuCl}$ and its partial pressure would be

$$
\mathrm{P}_{\mathrm{Cu}_{3} \mathrm{Cl}}=(\mathrm{HCl})^{3} \mathrm{~K}_{12} /\left(\mathrm{H}_{2} \mathrm{O}\right)^{3 / 2}\left(\mathrm{O}_{2}\right)^{3 / 4}
$$

from the reaction

$$
3 \mathrm{CuO}+3 \mathrm{HCl}(\mathrm{g}) \rightleftarrows \mathrm{Cu}_{3} \mathrm{Cl}_{3}(\mathrm{~g})+3 / 2 \mathrm{H}_{2} \mathrm{O}(\mathrm{g})+3 / 4 \mathrm{O}_{2}(\mathrm{~g}) \text {. }
$$

An opposite case is tin. Although $\mathrm{SnCl}_{2}$ is exceptionally volatile, the stability of $\mathrm{SnO}_{2}$ (nonvolatile) is great enough that extensive volatilization should be prevented by the reaction

$$
\mathrm{SnCl}_{2}(\mathrm{~g})+\mathrm{O}_{2}(\mathrm{~g}) \rightleftarrows \mathrm{SnO}_{2}+\mathrm{Cl}_{2}(\mathrm{~g})
$$

or, more accurately, by

$$
\mathrm{SnCl}_{2}(\mathrm{~g})+\mathrm{H}_{2} \mathrm{O}(\mathrm{g})+1 / 2 \mathrm{O}_{2}(\mathrm{~g}) \rightleftarrows \mathrm{SnO}_{2}+2 \mathrm{HCl}(\mathrm{g}) \text {. }
$$


For reaction (14), $\Delta \mathrm{G}=-163 \mathrm{KJ}$ at $1000 \mathrm{~K}$ and $-93 \mathrm{~kJ}$ at $1500 \mathrm{~K}$.

Using free-energy data, and equations similar to (2 through 14), values of the equilibrium constant, $K$, and the partial pressures of volatile compounds that are estimated to be significant have been calculated for many compounds of the elements in Table 1 at 500, 1000, and $1500 \mathrm{~K}$.

Figures 3 through 5 show the calculated free energies of the reactions forming chlorides for metals of concern. In each case, the starting compound is taken as the most stable compound in the air- $\mathrm{CO}_{2}$-water vapor system at the temperature in question. Most often this is an oxide. As noted above, for the alkali metals the most stable is the carbonate, and for $\mathrm{Au}, \mathrm{Ag}$, and $\mathrm{Hg}$ it is the free metal. The reference point used for free-energy data of a compound involved in a reaction is that of the element in its standard state. The superscript zero (e.g., $\Delta G^{\circ}$ indicating the referenced standard state) has been omitted in this paper. For liquids and solids, the requirement of the pure respective phases, liquid or solid, will not generally be met since solutions of widely varying concentrations may be more common. No attempt was made to estimate activity coefficients of the components. For the plotted data, the pure condensed phases are assumed. The inflection points will normally be transition points, e.g., melting, or vaporization.

The extremes in chloride stability are seen in Figure 3 , while Figures 4 and 5 show differences among the transition and similar metals.

Since the total metals may be in excess of the halogens it is important to compare the free energies for reactions such as (3) and (4) for the various elements. As an example, with limited $\mathrm{HCl}, \mathrm{FeCl}_{3}$ (the above example), or its dimer may not form at a71. This is because it is chemically much less stable than the chlorides of many of the other metals (see Figure 3 ).

In many cases, other salts may be more stable than the chlorides, thus preventing volatilization. The sulfates of most metals, for example, are more stable than the chlorides and are nonvolatile. However, in turn, most of them decompose at temperatures well below $1500 \mathrm{~K}$. Thus, sulfates from sulfur in 


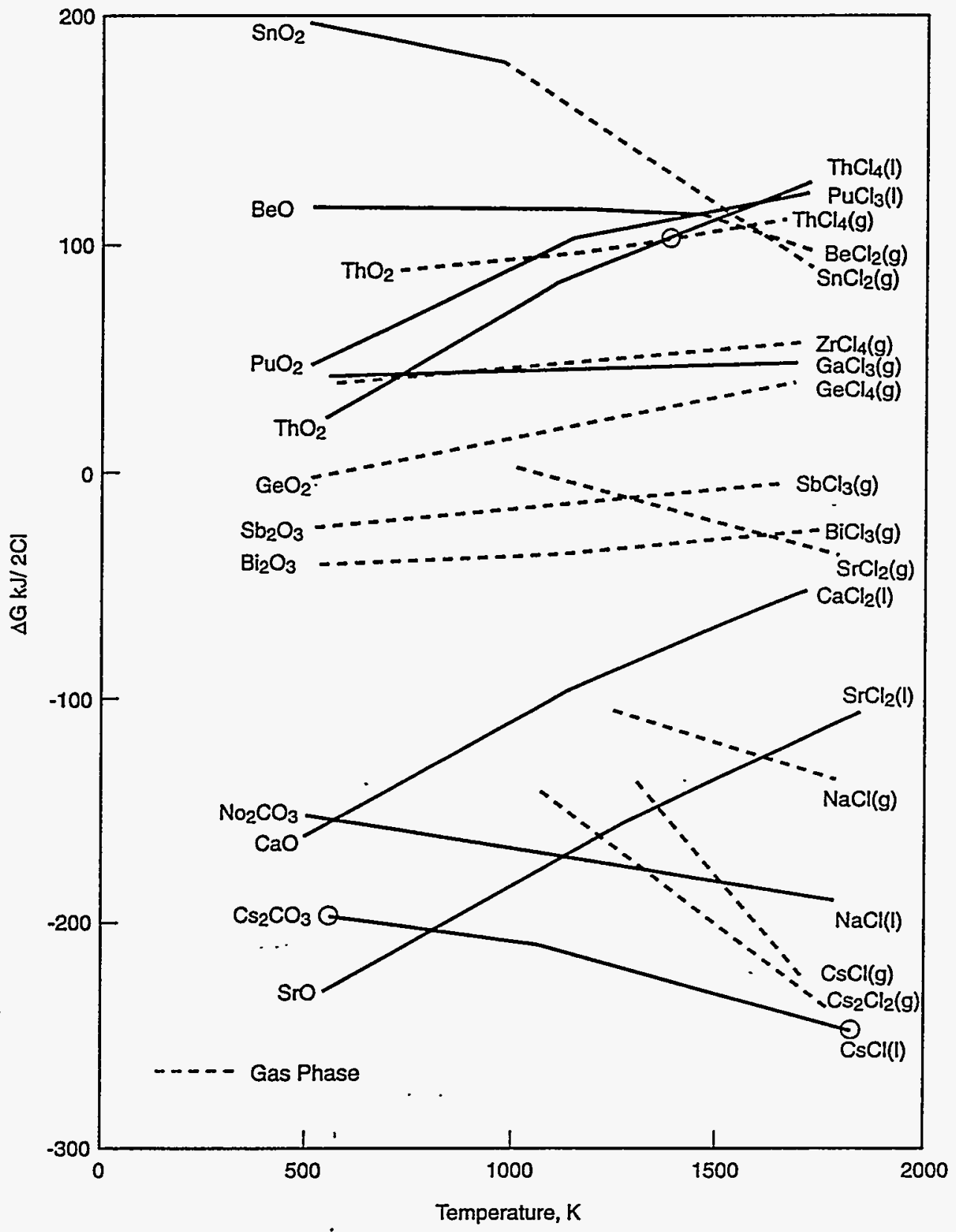

59409030.5

FIGURE 3. Calculated Free Energies of Reaction, as a Function of Temperature $(500 \mathrm{~K}$ to $1500 \mathrm{~K}$ ), for Metal 0xides Forming Chlorides: $\mathrm{Cr}, \mathrm{Cn}, \mathrm{Fe}, \mathrm{Ni}$, and $\mathrm{Hg}$. 


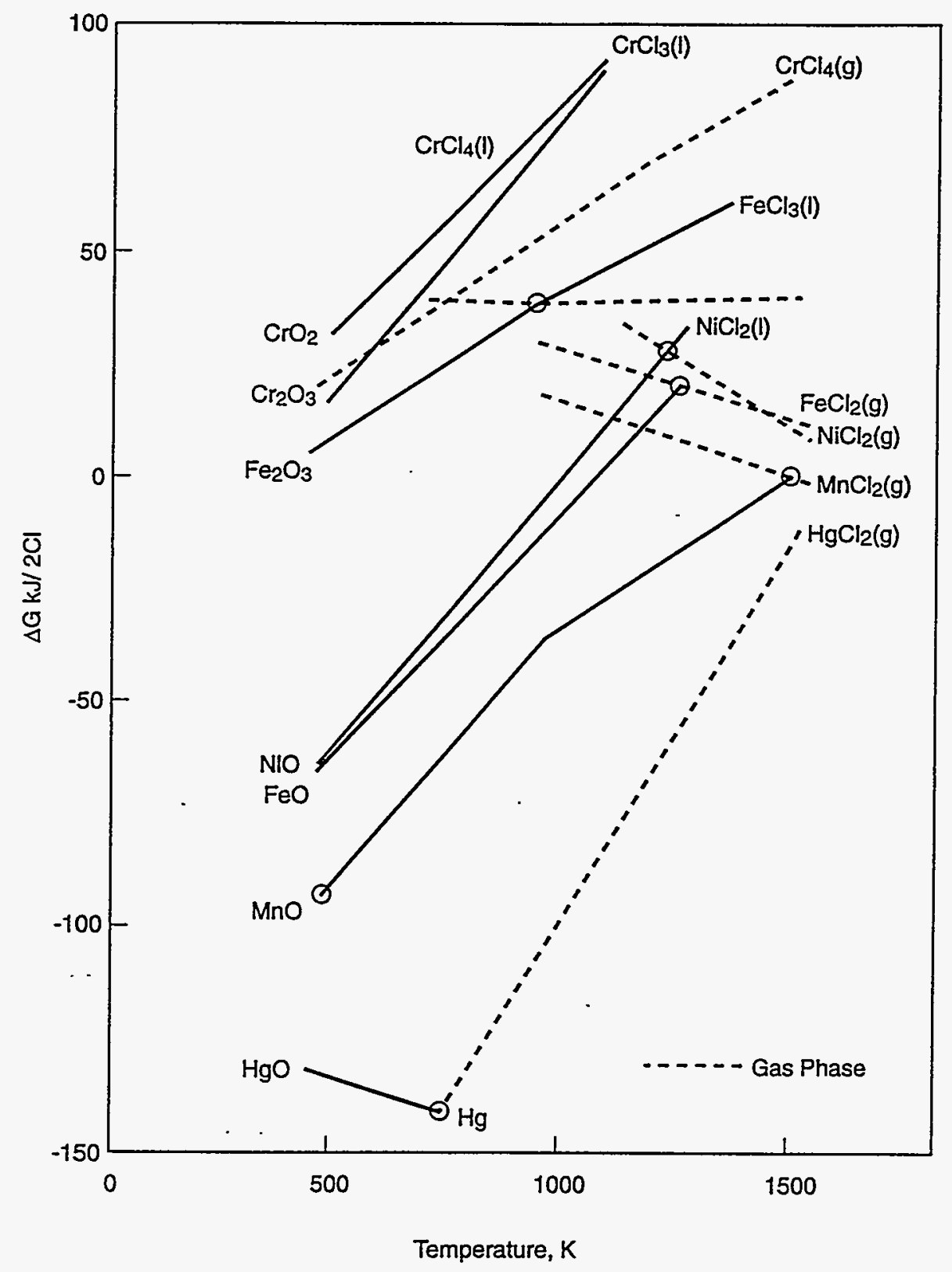

$\$ 9409030.7$

FIGURE 4. Calculated Free Energies of Reaction, as a Function of Temperature ( $500 \mathrm{~K}$ to $1750 \mathrm{~K}$ ), for Metal 0xides Forming Chlorides: $\mathrm{Na}, \mathrm{Cs}, \mathrm{Be}, \mathrm{Ca}, \mathrm{Sr}, \mathrm{Ge}, \mathrm{Sn}, \mathrm{Sb}, \mathrm{Bi}, \mathrm{Th}$, and $\mathrm{Pu}$ 


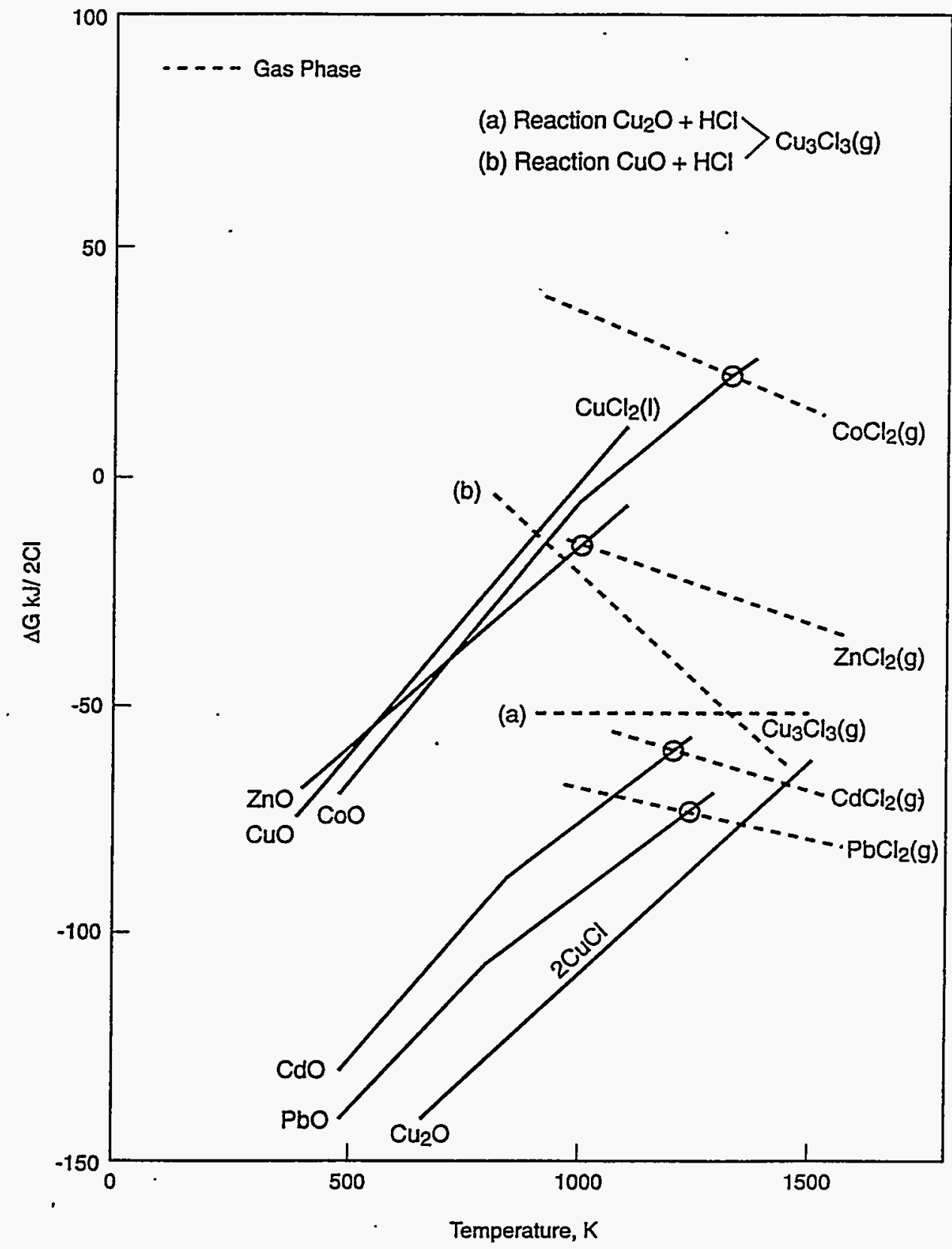

59409030.6

FIGURE 5. Calculated Free Energies of Reaction, as a Function of Temperature ( $500 \mathrm{~K}$ to $1500 \mathrm{~K}$ ), for Metal 0xides Forming Chlorides: $\mathrm{Co}, \mathrm{Cu}, \mathrm{Zn}, \mathrm{Cd}$, and $\mathrm{Pb}$ 
the incinerator feed could significantly reduce volatility of many metals at temperatures up to slightiy greater than $1000 \mathrm{~K}$, provided that the kinetics are such that appreciable $\mathrm{SO}_{2}$ is converted to $\mathrm{SO}_{3}$. Sulfur would normally be burned to $\mathrm{SO}_{2}$. Although $\mathrm{SO}_{3}$ is thermodynamicaliy more stable at the lower temperatures. of interest, it is not easily formed in the absence of catalysts. Its stability decreases with increase in temperature and by $1500 \mathrm{~K}$ it has mostly converted back to $\mathrm{SO}_{2}$ (Ephraigm 1973). Nitric oxide, which will be present, both as a result of nitrate/nitrite decomposition and from the high temperature $\mathrm{N}-0$ reaction, is a potential homogeneous catalyst for oxidation of $\mathrm{SO}_{2}$.

The relative stability of several sulfates is shown in Figure 6. Data are for the reaction $\mathrm{MO}+\mathrm{SO}_{3}(\mathrm{~g})$. Extrapolation to temperatures below about $800 \mathrm{~K}$ requires correction for the reaction $\mathrm{SO}_{3}(\mathrm{~g})+\mathrm{H}_{2} \mathrm{O}(\mathrm{g}) \rightleftarrows \mathrm{H}_{2} \mathrm{SO}_{4}(\mathrm{~g})$. At the higher temperatures the reactive species is $\mathrm{SO}_{2}$. The correction for $\mathrm{SO}_{2}$ at $1200 \mathrm{~K}$ is about $+13 \mathrm{~kJ} / \mathrm{mol}$ and at $1400 \mathrm{~K}$.about $+30 \mathrm{~kJ}$.

Fluorine also forms very stable metal compounds and those of the higher oxidation states of all the elements are generally volatile. In a very few cases the fluoride may be the principal volatile species, although the metals that form volatile fluorides normally form oxides that are equally or more stable.

In the absence of more stable anionic species, and if sufficient $\mathrm{HCl}$, for example, is present, the metals that form stable volatile chlorides will theoretically exist as metal chlorides. If there is a deficiency, then the available $\mathrm{Cl}$ will partition among the metals according to thermodynamic equilibria. It becomes obvious that determination of chemical species and their equilibrium concentrations in a mixture of metals and $\mathrm{Cl}, \mathrm{F}, \mathrm{O}, \mathrm{S}, \mathrm{P}$, and $C$ as major components is not a trivial task, even at a single temperature.

Chlorinated solvents and polyvinyl chloride, PVC, are ready sources of $\mathrm{HCl}$. Teflon and similar polymers are sources of $F$. Various other organic materials may be sources of $S$ and $P$. 


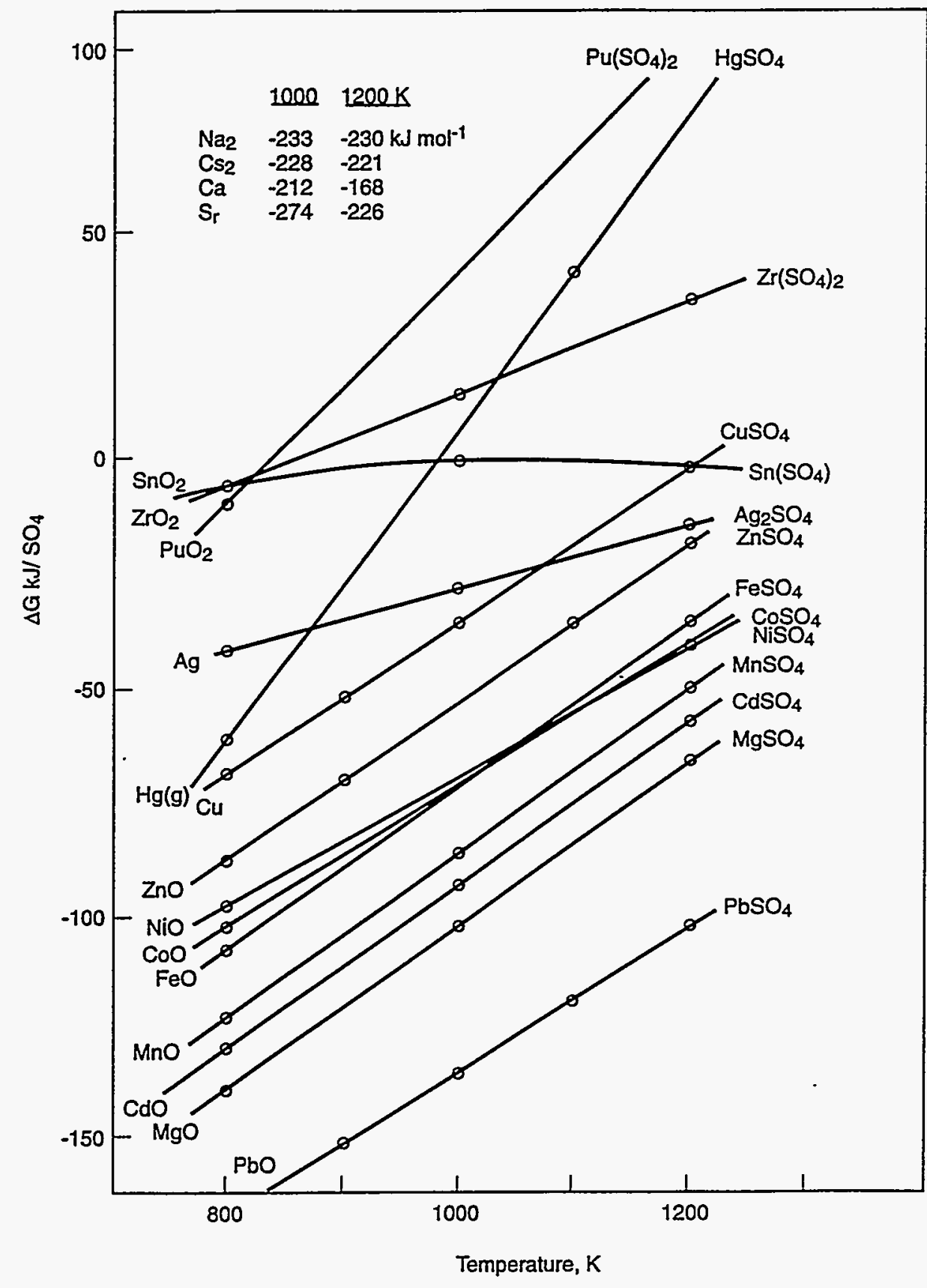

59409030.8

FIGURE 6. Calculated Free Energies of Reaction, as a Function of Temperature $(800 \mathrm{~K}$ to $1200 \mathrm{~K})$, for. Metal 0xides Forming Sulfates from $\mathrm{SO}_{3}$ : $\mathrm{Mg}, \mathrm{Mn}, \mathrm{Fe}, \mathrm{Co}, \mathrm{Ni}, \mathrm{Cu}, \mathrm{Zn}, \mathrm{Zr}, \mathrm{Ag}, \mathrm{Cd}, \mathrm{Sn}, \mathrm{Hg}, \mathrm{Pb}$, and $\mathrm{Pu}$ 
Formation of volatile species is one issue. Formation of intractible solids may be another. Similar chemistry will affect the composition of, and hence the physical properties of, the ash or slag. For example, borates form low melting glasses with many metals. Silicates may comprise a major fraction of the solid products. The proportions of major elements such as $\mathrm{Na}, \mathrm{Ca}, \mathrm{Al}$, $\mathrm{Si}, \mathrm{Fe}, \mathrm{S}$, and $\mathrm{B}$ may determine the melting points and other physical properties of the burner ash and thus the nature of the slag.

The other Group VI elements in Table 1 also show nonmetallic properties, and the oxides are very volatile. Tellurium shows some metallic properties, but $\mathrm{TeO}_{2}$ still has a calculated vapor pressure of 0.1 torr at $1000 \mathrm{~K}$ and 8 torr at $1200 \mathrm{~K}$. $\mathrm{SeO}_{2}$ is quite soluble in water as is $\mathrm{SO}_{3} ; \mathrm{SO}_{2}$ is slightly soluble; and $\mathrm{TeO}_{2}$ is insoluble (Ephraigm 1953).

The most stable form of phosphorus is $\mathrm{P}_{4} \mathrm{O}_{10}$, sublimation point $259^{\circ} \mathrm{C}$ $(532 \mathrm{~K})$, although some $\mathrm{P}_{4} \mathrm{O}_{6}$, bp $173^{\circ} \mathrm{C}(446 \mathrm{~K})$, may exist. However, $\mathrm{P}_{4} \mathrm{O}_{10}$ has a high affinity for $\mathrm{H}_{2} \mathrm{O}$, and it may exist in the form of an $\mathrm{H}_{3} \mathrm{PO}_{4}$ mist below about $800 \mathrm{~K}$. Alternatively, it may be retained in the ash as solid metal phosphates. Calcium phosphate is one of the more stable metal phosphates. Strontium phosphate is expected to be similar. Data to prepare plots for phosphates similar to those in Figures 3 through 6 are not available. A few cases will be considered later.

Arsenic has both acidic and metallic properties. The stability of the 5-valent oxides of Group $V$ elements decreases with atomic number and also as the temperature rises. It is likely that the 3 -valent $\mathrm{As}_{2} \mathrm{O}_{3}$ is the most stable As compound in our system and can readily volatilize, largely as $\mathrm{As}_{4} 0_{6}$. It is slightly soluble in $\mathrm{H}_{2} \mathrm{O}$. Antimony continues the trend. The gas $\mathrm{Sb}_{4} \mathrm{O}_{6}$ is stable to very high temperatures (Ephraigm 1953). Its calculated vapor pressure is 3.6 torr at $900 \mathrm{~K}$ and 14 torr at $1000 \mathrm{~K}$.

The halides of As and Sb are very volatile. Although they are hydrolyzed by $\mathrm{H}_{2} \mathrm{O}$, both the the trifluorides and the trichlorides could readily volatilize if the respective acid concentrations are great enough. For HCl at 
a concentration of $0.01 \mathrm{~atm}$ ( $\sim 8$ torr), and when $\mathrm{H}_{2} \mathrm{O}=0.25 \mathrm{~atm}$ (190 torr) (Table 2), the calculated partial pressure of $\mathrm{SbCl}_{3}$ at $1000 \mathrm{~K}$ is $4 \mathrm{E}-04 \mathrm{~atm}$ ( 0.3 torr). If the HF concentration exceeds the $\mathrm{HCl}$ concentration by an order of magnitude, the gas phase would become $\mathrm{SbF}_{3}$. At low halogen concentrations the predominant gaseous species should be $\mathrm{Sb}_{4} \mathrm{O}_{6}$.

Bismuth shows little acidic character but is discussed here since it is in Group V. It forms stable oxides and halides; the latter are volatile. Bismuth appears to be the only one of this family whose chloride, $\mathrm{BiCl}_{3}$, is sufficiently more stable than the oxide such that it can preferentially exist in the $\mathrm{H}_{2} \mathrm{O}$ environment. Its partial pressure at $1000 \mathrm{~K}$ is calculated to be, for $\mathrm{H}_{2} \mathrm{O}=0.25 \mathrm{~atm}$,

$$
\mathrm{P}_{\mathrm{BiCl}_{3}}=1 \mathrm{E}+04(\mathrm{HCl})^{3} \mathrm{~atm} .
$$

The cubic dependence of $\mathrm{HCl}$ indicates that its concentration must be about $0.01 \mathrm{~atm}$ or greater to give an appreciable gaseous $\mathrm{BiCl}_{3}$ concentration. The oxychloride, BiOCl, can also form.

Boron, aluminum, and silicon may have a different role. The halides are very volatile but should not form due to the great stability of the oxides. Their importance could be that they can combine with many metal oxides, forming borates, aluminates, and silicates, respectively. With abundant sodium or calcium, for example, they can influence the nature of the burner ash or slag, especially the melting point. As mentioned above, $\mathrm{Ti}$ and $\mathrm{Zr}$ can behave similarly.

Tritium and ${ }^{14} \mathrm{C}$ were discussed earlier. Since $\mathrm{CO}_{2}$ is in great excess over the other acidic gases, it is possible that a portion may remain with the ash, depending on the temperature and the total quantities of Groups IA and IIA elements, and, of course, on the concentrations of other acid gases. 


\section{GROUPS IA AND IIA ELEMENTS}

The alkali and alkaline earth metals need special mention for two reasons. Their salts, especially the halides, the sulfates, and many of the phosphates, are stable to very high temperatures. The vapor pressures of Group IIA compounds are generally low, but those of the halides of Group IA are appreciable as the data of Table 3 show.

The metals of Groups IA and IIA are expected to be present in large amounts in incinerator feed materials. Thus, they can act as potential sinks for compounds that would otherwise promote low-temperature volatility. But, they could also scavenge compounds that prevent volatility, e.g., sulfates.

Calcium forms the most stable fluoride of the metals likely to be present in waste in appreciable concentrations. For chloride the most stable is $\mathrm{Na}$. It is notable that the corresponding salts of $\mathrm{Sr}$ are often more stable than the Ca salts (examples are the carbonate, sulfate and chloride salts), and those of $\mathrm{Cs}$ are more stable than the $\mathrm{Na}$ salts.

Sodium and Cs, elements of concern here (Table 1), are expected to be stable as the solid sulfates if the $\mathrm{H}_{2} \mathrm{SO}_{4},\left(\mathrm{SO}_{3}+\mathrm{H}_{2} \mathrm{O}\right)$, concentration is high. Otherwise, appreciable vaporization as the chloride could occur at moderately high temperatures. At sti11 higher temperatures, above about 1200 or $1300 \mathrm{~K}$, the sulfates may be too unstable to offer any protection. Strontium and Ra are expected to remain as solids, primarity as sulfates or phosphates, or, in the absence of the latter, as chlorides or fluorides. The fluoride of $\mathrm{Sr}$ is more stable than the chloride. This is not true for Ba and, thus, presumably not for Ra. Strontium forms one of the most stable sulfates.

Beryllium is potentially different in that the chloride is very volatile ( $b p=804 \mathrm{~K}$ ), but the oxide is sufficiently stable that the partial pressure of $\mathrm{BeCl}_{2}$ becomes extremely low. The sulfate should preferentially form in place of chloride but will decompose before $1000 \mathrm{~K}$ is reached. The fluoride appears to be the most stable Be salt and it is slightly volatile. However, its calculated equilibrium partial pressure with $\mathrm{HF}=0.01 \mathrm{~atm}(1 \mathrm{~mol} \%)$ is 
only about 3E-04 torr at $1500 \mathrm{~K}$. Thus, Group II elements are predicted to preferentially stay in the ash. The same should be true for Group I elements if the halogen concentration is low.

\section{TRANSITION ELEMENTS AND GROUP IIB}

The transition elements include many of the elements in TabTe 1. Characteristically they show multiple oxidation states and the volatility of their compounds increases with oxidation number. The fluorides are of special interest for the first members of the series; as the $d$ shell fills, the chlorides become relatively more stable. Equilibria of the type expressed in Equations (2) through (14) should be important.

In genera1, the oxides will be the stable species. This is especially true for the first elements of the three rows. Thus, although $\mathrm{Zr}, \mathrm{V}$, and $\mathrm{Nb}$ form volatile halides, they readily hydrolize to stable oxides and are nonvolatile. In the case of $\mathrm{Zr}$, the fluoride $\mathrm{ZrF}_{4}$, with $\mathrm{P}=0.019 \mathrm{~atm}$ at $1000 \mathrm{~K}$, could volatilize only if the HF concentration were exceptionally high, i.e., $H F>\mathrm{H}_{2} \mathrm{O}$. Technetium and ruthenium have very volatile oxides (Table 5). The oxide $\mathrm{RuO}_{4}$ is a gas above a few hundred degrees $\mathrm{K}$ (bp $373 \mathrm{~K}$ ). It may be formed from $\mathrm{RuO}_{2}$ and $\mathrm{O}_{2}$ or $\mathrm{NO}_{2}$. It has a tendency to collect on solid surfaces or particles. There is some evidence that other volatile Ru compounds exist perhaps involving nitroso groups (Christian 1990). The lower-oxide $\mathrm{RuO}_{2}$ is volatile at temperatures above about $1000 \mathrm{~K}$.

Technetium forms a series of oxides, the most stable of which are probably $\mathrm{TcO}_{3}$ and $\mathrm{Tc}_{2} \mathrm{O}_{7}$. The latter is very volatile, bp $584 \mathrm{~K}$, and may be the predominant form in the incinerator.

Chromium is important because the VI state is toxic. The oxide $\mathrm{Cr}_{2} \mathrm{O}_{3}$ should normally be the stable species. However, in the presence of alkali metal salts, such as nitrate or carbonate, it may be converted to $\mathrm{Na}_{2} \mathrm{CrO}_{4}$ (Ephraigm 1953). The reaction 


$$
\mathrm{Cr}_{2} \mathrm{O}_{3}+2 \mathrm{Na}_{2} \mathrm{CO}_{3}+1.5 \mathrm{O}_{2} \rightleftarrows 2 \mathrm{Na}_{2} \mathrm{CrO}_{4}+2 \mathrm{CO}_{2}
$$

is very favorable in the incinerator atmosphere. The compound $\mathrm{CrO}_{2} \mathrm{Cl}_{2}$ is very volatile, b.p. $390 \mathrm{~K}$, but is only stable at high $\mathrm{HCl}$ concentrations, $(\mathrm{HCl}) \gg\left(\mathrm{H}_{2} \mathrm{O}\right)$. No other volatile $\mathrm{Cr}$ (VI) compounds are expected. It is notable that many $\mathrm{Cr}$ (VI) compounds are soluble in water, important in off-gas scrubbing. The most stable oxide of $\mathrm{Mn}$ is $\mathrm{Mn}_{2} \mathrm{O}_{3}$ although the stability of $\mathrm{MnO}$ increases at the higher temperatures. The dichloride is intermediate in stability in the transition metals, but the boiling point of $\mathrm{MnCl}_{2}$ is $1463 \mathrm{~K}$ and little volatility would be expected. The higher chlorides are more volatile but should be unstable in the incinerator atmosphere.

Towards the $\mathrm{Cu}$ end of the series, the chlorides, along with those of Group IIB, become more stable relative to the oxides and fluorides. As i7 Tustrated in Section 4.1, many could volatilize as the chlorides if the $\mathrm{HCl}$ concentration is high, the $\mathrm{H}_{2} \mathrm{O}$ concentration low, and competing anions are absent. The metals $\mathrm{Fe}$ and $\mathrm{Cu}$ were discussed earlier.

An interesting example is $\mathrm{Zn}$ since the chloride is very volatile, $\mathrm{bp}=999 \mathrm{~K}$. For the metal oxide-chloride equilibrium with $0.25 \mathrm{~atm} \mathrm{H}_{2} \mathrm{O}$, we find at $1000 \mathrm{~K}$

$$
\mathrm{P}_{\mathrm{ZnCl}_{2}}=2.6 \mathrm{E}+03(\mathrm{HCT})^{2} \mathrm{~atm} .
$$

At $\mathrm{HCl}=0.01 \mathrm{~atm}, \mathrm{P}=198 \mathrm{torr}$, and at $\mathrm{HCl}=0.001, \mathrm{P}=2.0$ torr. Thus, we might expect $\mathrm{ZnCl}_{2}$ to readily vaporize. Again, however, the sulfate is more stable, and the presence of sulfur may reduce volatility. On the other hand, $1000 \mathrm{~K}$ is approximately the temperature at which $\mathrm{ZnSO}_{4}$ begins to decompose, and thus it is questionable whether the available $\mathrm{SO}_{3}$ can prevent volatilization if the temperature is much greater than $1000 \mathrm{~K}$.

The same complex behavior would be expected for $\mathrm{Cd}, \mathrm{Hg}$, and $\mathrm{Pb}$. However, differences might be predicted: The vapor pressures of the pure dichlorides are in the order $\mathrm{Hg}>\mathrm{Zn}>\mathrm{Pb}>\mathrm{Cd}$ (Table 3). The thermodynamic 
stability of the sulfates with respect to the oxides is in the order $\mathrm{Pb}->\mathrm{Cd}>$ $\mathrm{Zn}>\mathrm{Hg}$ (Figure 5). Thus, the resulting volatility under the conditions of Table 3, depending on the sulfate concentration and the temperature, could conceivably be $\mathrm{Hg}>\mathrm{Cd}>\mathrm{Zn},>\mathrm{Pb}$. In the absence of complexing anions such as sulfate and halides, compounds of these elements, e.g., carbonates, could decompose to the free metals above about $1300 \mathrm{~K}$. The relative volatility might then become $\mathrm{Hg} \gg \mathrm{Cd} \gg \mathrm{Pb} \gg \mathrm{Zn}$.

Lead, of course, does not belong in Group IIB but is often compared in behavior to the other three metals. Its vapor pressure is low compared with that of $\mathrm{Cd}$. The metal vapor pressures were compared in Table 5. The extreme range of vapor pressures of several metals of interest is shown in Table 7.

IABLE 7. Approximate Temperatures Giving Vapor Pressures Equal to that of $\mathrm{Hg}$ at $298 \mathrm{~K}, 2.4 \mathrm{E}-06 \mathrm{~atm}$

$\begin{array}{llll}\mathrm{Hg} & 298 \mathrm{~K} & \mathrm{Mn} & 1150 \\ \mathrm{Cd} & 490 & \mathrm{Ag} & 1220 \\ \mathrm{Na} & 520 & \mathrm{Ga} & 1240 \\ \mathrm{Zn} & 570 & \mathrm{~A} 7 & 1380 \\ \mathrm{Sr} & 740 & \mathrm{Cu} & 1430 \\ \mathrm{Sb} & 770 & \mathrm{Au} & 1550 \\ \mathrm{Bi} & 870 & \mathrm{Pu} & 1650 \\ \mathrm{~Pb} & 910 & \mathrm{Ni} & 1710\end{array}$

\section{GROUPS IIIA AND IVA ELEMENTS}

Aluminum has been discussed earlier. Its chloride is very volatile, $b p=454 \mathrm{~K}$, but the oxide is so stable that the concentrations of Al halides should be negligible.

Gallium, Ge, In, $\mathrm{Sn}$, and $\mathrm{Pb}$ fall into this group. It is notable that the fluoride of In is more stable than the oxide. However, it is not volatile. 
Lead is often a metal of concern in incineration. Of the oxides, $\mathrm{PbO}$ is the most stable over most of the temperature range considered. Yet, chloride volatility could result from the relatively low stability of the oxide. But lead forms one of the more stable sulfates and the compound may exist at temperatures well above $1000 \mathrm{~K}$ and prevent the chloride from forming. Lead was considered in examples in Section 2.2.

Tin was discussed as an example in Section 2.2, Equations (11) and (12). The boiling point of $\mathrm{SnCl}_{2}$ is only $885 \mathrm{~K}$. However, the oxide, $\mathrm{SnO}_{2}$, is so much more stable that in our system of $\mathrm{O}_{2}=0.1$ and $\mathrm{H}_{2} \mathrm{O}=0.2 \mathrm{~atm}$, the partial pressure of $\mathrm{SnCl}_{2}$ is not significant at low HCl concentrations, about $1 \mathrm{E}-06$ atm at $1500 \mathrm{~K}$ if $\mathrm{HCl}$ is $1 \%$.

\section{LANTHANIDE AND ACTINIDE ELEMENTS}

The 1 anthanides and actinides are characterized by very stable oxides and fluorides. The higher oxidation state chlorides and fluorides of the actinides are very volatile. Inspection of $\Delta G_{f}$ data suggests that $\mathrm{CeF}_{3}$ could form as the solid but would not be volatile. No volatile.lanthanide species are likely.

The actinides present a more involved case in that they exhibit more oxidation states and the stability of each state varies throughout the series. Although the chlorides and fluorides are very stable and the higher ones are very volatile, it appears from the gas composition of Table 2 that the oxides will be the important species. The predominant compounds are expected to be $\mathrm{ThO}_{2}, \mathrm{UO}_{3}$ and $\mathrm{U}_{3} \mathrm{O}_{8}, \mathrm{NpO}_{2}, \mathrm{PuO}_{2}$, and $\mathrm{Am}_{2} \mathrm{O}_{3}$ and $\mathrm{AmO}_{2}$.

\section{COMPLEX EQUILIBRIA MODEL CALCULATIONS}

Several programs are available for calculating thermodynamic equilibria of mixtures. "HSC Chemistry for Windows"(a) was used here for a large

(a). "HSC Chemistry for Windows" Version 2.01, Outokumpu Research, Finland. Distibuted by ARS Software, Landover, MD. 
number of calculations, many involving 50 to 100 chemical species in the condensed and gaseous states. Many uncertainties exist, in large part due to a lack of knowledge of the composition of the condensed state, i.e., how many phases exist and which compounds are in a given phase. A7so, no information on thermodynamic activities is available. However, it appears worthwhile to use the calculations to predict relative concentrations of species in several mixtures. A few of the results are reported here.

As an example, using the initial gas compositions, similar to those of Table 2, the equilibrium composition as a function of temperature at $1 \mathrm{~atm}$ pressure was calculated for 27 compounds, conceivably significant in the equilibrium mixture at $1000 \mathrm{~K}$ to $1500 \mathrm{~K}$. The starting composition, mols added, is listed as Test 1 in Table 8 (Figures 7 through 13 show calculations for each test noted in Table 8). Compounds calculated to have concentrations above $1 \mathrm{E}-08 \mathrm{~mol} \%$ are shown in Figures $7 \mathrm{a}$ and $7 \mathrm{~b}$. The gases $\mathrm{N}_{2}, \mathrm{CO}_{2}$, and $\mathrm{H}_{2} \mathrm{O}$ were essentially unchanged and are not shown. Note that above $1000 \mathrm{~K}$ the most stable compounds of $\mathrm{Cl}, \mathrm{N}, \mathrm{S}$, and $\mathrm{P}$ are the gases $\mathrm{HCl}, \mathrm{NO}, \mathrm{SO}_{2}$, and $\mathrm{P}_{4} \mathrm{O}_{10}$, respective1y, as suggested in Section 2.2.

Table 8 lists the feed compositions used for several other calculations. The model uses the most stable species that will exist, based on the element input, using its data base of about 7000 compounds. We reduce this list to norma17y 40 to 100 compounds based on compatibility with a "wet" oxidizing system for the temperature range to be studied. Figure 8 shows the behavior of $\mathrm{Na}$ and $\mathrm{Ni}$ when added to the $\mathrm{HCT}-\mathrm{H}_{2} \mathrm{O}-\mathrm{O}_{2}$ atmosphere. The composition of the initial mixture is 1isted as Test 2. For Figure $8 \mathrm{~b}$, the $\mathrm{HCl}$ concentration was increased by a factor of 5 over that in Figure 8a. The increases in partial pressures of $\mathrm{NaCl}$ and $\mathrm{NiCl}_{2}$ are roughly as expected from Equation (7). Figures $8 \mathrm{c}$ and $8 \mathrm{~d}$ show the result of reducing the sodium carbonate from 0.1 to $0.01 \mathrm{mols}$, leaving the system highly acidic. Under these conditions, nearly all the $\mathrm{Cl}$ is in the vapor phase, mostly as $\mathrm{HCl}$ and $\mathrm{NaCl}(\mathrm{g})$. At $0.1 \mathrm{~mol}$ $\mathrm{Na}_{2} \mathrm{CO}_{3}$, most of the $\mathrm{Cl}$ appears as condensed $\mathrm{NaCl}$. The condensed phase components for the high-acid case are shown in Figure 8d. Nickel sulphate 
TABLE 8. Feed Compositions used for HSC Tests mols added, $P=1.0 \mathrm{~atm}$

\begin{tabular}{|c|c|c|c|c|c|c|c|}
\hline Compound & Test 1 & Test 2 & Test 3 & Test 4 & Test 5 & Test 6 & Test 7 \\
\hline $\mathrm{H}_{2} \mathrm{O}$ & 0.20 & 0.20 & 0.10 & 0.10 & 0.15 & 0.15 & 0.15 \\
\hline $0_{2}^{c}$ & 0.10 & 0.10 & 0.10 & 0.10 & 0.10 & 0.10 & 0.10 \\
\hline $\mathrm{CO}_{2}$ & 0.10 & 0.10 & 0.10 & 0.10 & 0.10 & 0.10 & 0.10 \\
\hline $\mathrm{N}_{2}{ }^{2}$ & 0.60 & 0.60 & 0.60 & 0.40 & 0.40 & 0.40 & 0.60 \\
\hline NO, & 0.01 & 0.01 & 0.02 & 0 & 0.02 & 0.02 & 0.02 \\
\hline $\mathrm{P}_{2} \mathrm{O}_{5}$ & 0.003 & 0 & 0 & 0 & 0 & & 0 \\
\hline $\mathrm{SO}_{2}{ }^{2}$ & 0.02 & 0.01 & 0 & 0.01 & 0.02 & 0.02 & 0.01 \\
\hline $\mathrm{HC}\{$ & 0.01 & $\begin{array}{l}0.01 \\
0.05^{(a)}\end{array}$ & 0.02 & 0.0 & 0.02 & & (e) \\
\hline HF & 0 & 0 & 0 & 0 & 0.02 & 0.02 & 0.01 \\
\hline $\mathrm{NaOH}$ & 0 & 0 & 0.02 & 0 & 0.01 & 0.01 & 0 \\
\hline $\mathrm{Na}_{2} \mathrm{CO}_{3}$ & 0 & $\begin{array}{l}0.10^{(a)} \\
0.01\end{array}$ & 0 & 0 & 0 & 0 & 0.005 \\
\hline $\mathrm{Na}_{2} \mathrm{SO}_{4}$ & 0 & 0.01 & 0 & 0 & 0 & 0 & 0 \\
\hline $\mathrm{CsOH}^{4}$ & 0 & 0 & 0 & 0.02 & 0.01 & 0.01 & 0 \\
\hline $\mathrm{Cs}_{2} \mathrm{CO}_{3}$ & 0 & 0 & 0 & 0.01 & 0 & 0 & 0.005 \\
\hline $\mathrm{CaO}$ & 0 & 0 & 0.03 & 0.01 & 0.005 & 0.005 & 0.005 \\
\hline $\mathrm{CaCl}_{2}$ & 0 & 0 & 0.05 & & 0 & 0 & 0 \\
\hline $\mathrm{SrO}^{\circ}$ & 0 & 0 & 0 & 0 & 0 & 0 & 0.005 \\
\hline MnO & 0 & 0 & 0 & 0 & 0.005 & 0.005 & 0 \\
\hline $\mathrm{FeO}$ & 0 & 0 & 0 & 0 & 0.005 & 0.005 & 0 \\
\hline $\mathrm{CoO}$ & 0 & 0 & 0 & 0 & 0.005 & 0.005 & 0.005 \\
\hline NiO & 0 & 0.01 & 0.01 & 0.01 & 0 & 0 & 0 \\
\hline CuO & 0 & 0 & 0.01 & 0.01 & 0.005 & 0.005 & 0 \\
\hline $\mathrm{CuSO}_{4}$ & 0 & 0 & (b) & 0 & 0 & & 0 \\
\hline $\mathrm{ZnO}$ & 0 & 0 & 0.01 & 0.01 & 0.005 & 0.005 & 0.005 \\
\hline $\mathrm{ZrO}_{2}$ & 0 & 0 & 0 & 0 & 0 & 0 & 0.005 \\
\hline $\mathrm{SnO} 0^{2}$ & 0 & 0 & 0 & 0 & 0 & 0.005 & 0 \\
\hline $\mathrm{PbO}$ & 0 & 0 & 0.01 & 0.01 & 0 & 0.005 & 0 \\
\hline $\mathrm{SbO}_{2}$ & 0 & 0 & 0 & 0 & 0 & 0 & 0.005 \\
\hline Figure & 7 & 8 & 9 & 10 & 11 & 12 & 13 \\
\hline
\end{tabular}
(a) Three different combinations were used in Test 2. See text.
(b) CuSO4 initial $=1.0 \mathrm{E}-04$, and added as 20 increments of $0.004 \mathrm{mots}$ each.
(c) $\mathrm{CaCl}_{2}$ initial $=1.0 \mathrm{E}-03$, and added in 15 increments of $0.003 \mathrm{mols}$ each.
(d) $\mathrm{HCl}$ initial $=2.0 \mathrm{E}-04$, added in 20 increments of $0.002 \mathrm{mols}$ each.
(e) $\mathrm{HCl}$ initial $=1.0 \mathrm{E}-03$, added in 20 increments of 0.0025 each. 


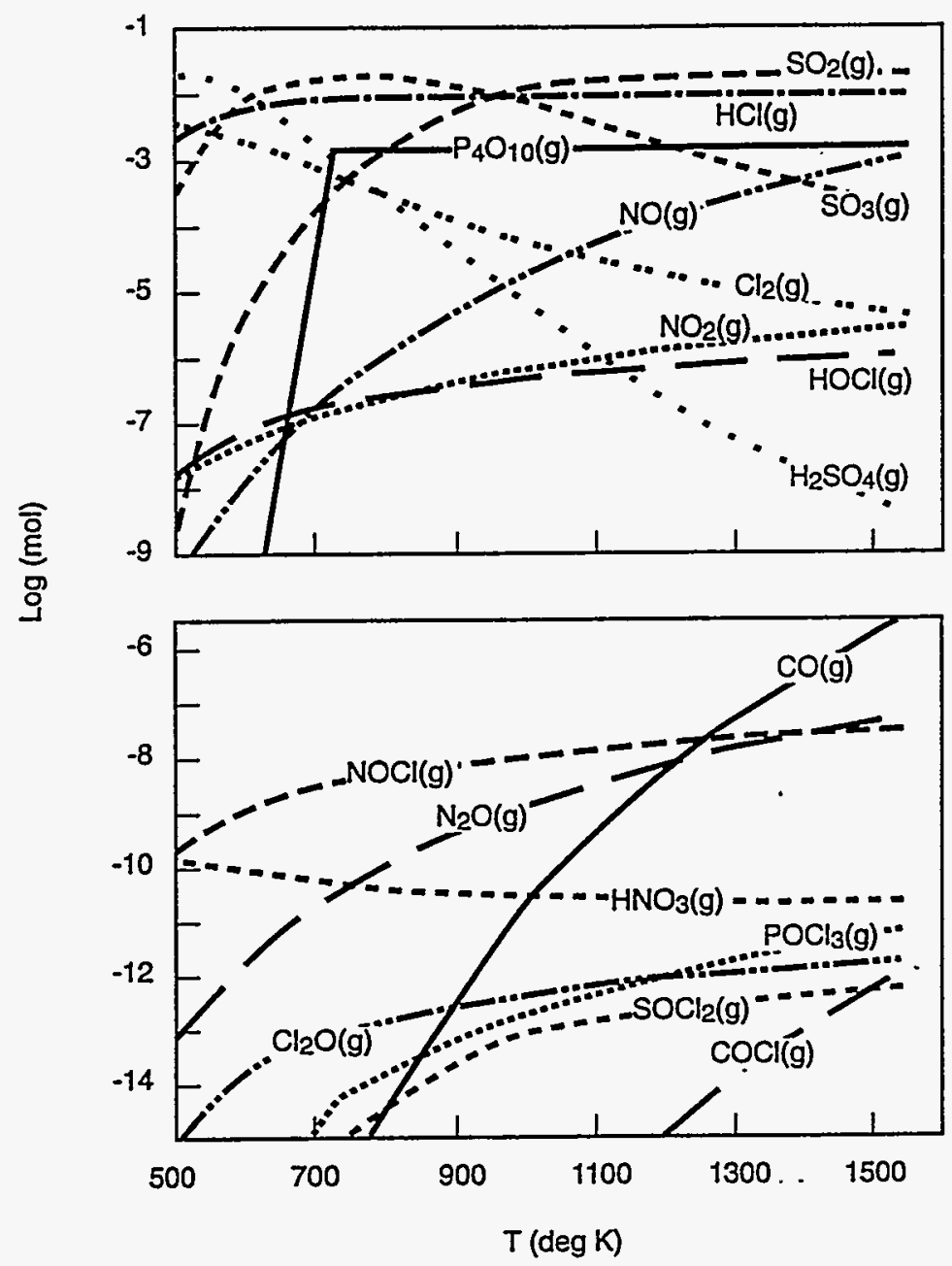

Feed Composition (mols)

\begin{tabular}{llll}
\hline $\mathrm{H}_{2} \mathrm{O}$ & 0.2 & $\mathrm{NO}_{2}$ & 0.01 \\
$\mathrm{O}_{2}$ & 0.1 & $\mathrm{P}_{2} \mathrm{O}_{5}$ & 0.003 \\
$\mathrm{CO}_{2}$ & 0.1 & $\mathrm{SO}_{2}$ & 0.02 \\
$\mathrm{~N}_{2}$ & 0.6 & $\mathrm{HCl}$ & 0.01
\end{tabular}

FIGURE 7a,b. Calculated Equilibrium Concentrations, as a Function of Temperature, $(500 \mathrm{~K}$ to $1500 \mathrm{~K})$, in Incinerator Off-Gas for an Initial Mixture of $\mathrm{H}_{2} \mathrm{O}, \mathrm{O}_{2}, \mathrm{CO}_{2}, \mathrm{~N}_{2}$, $\mathrm{NO}_{2}, \mathrm{SO}_{2}, \mathrm{P}_{2} \mathrm{O}_{3}$, and $\mathrm{HCl}$ (Test 1) 


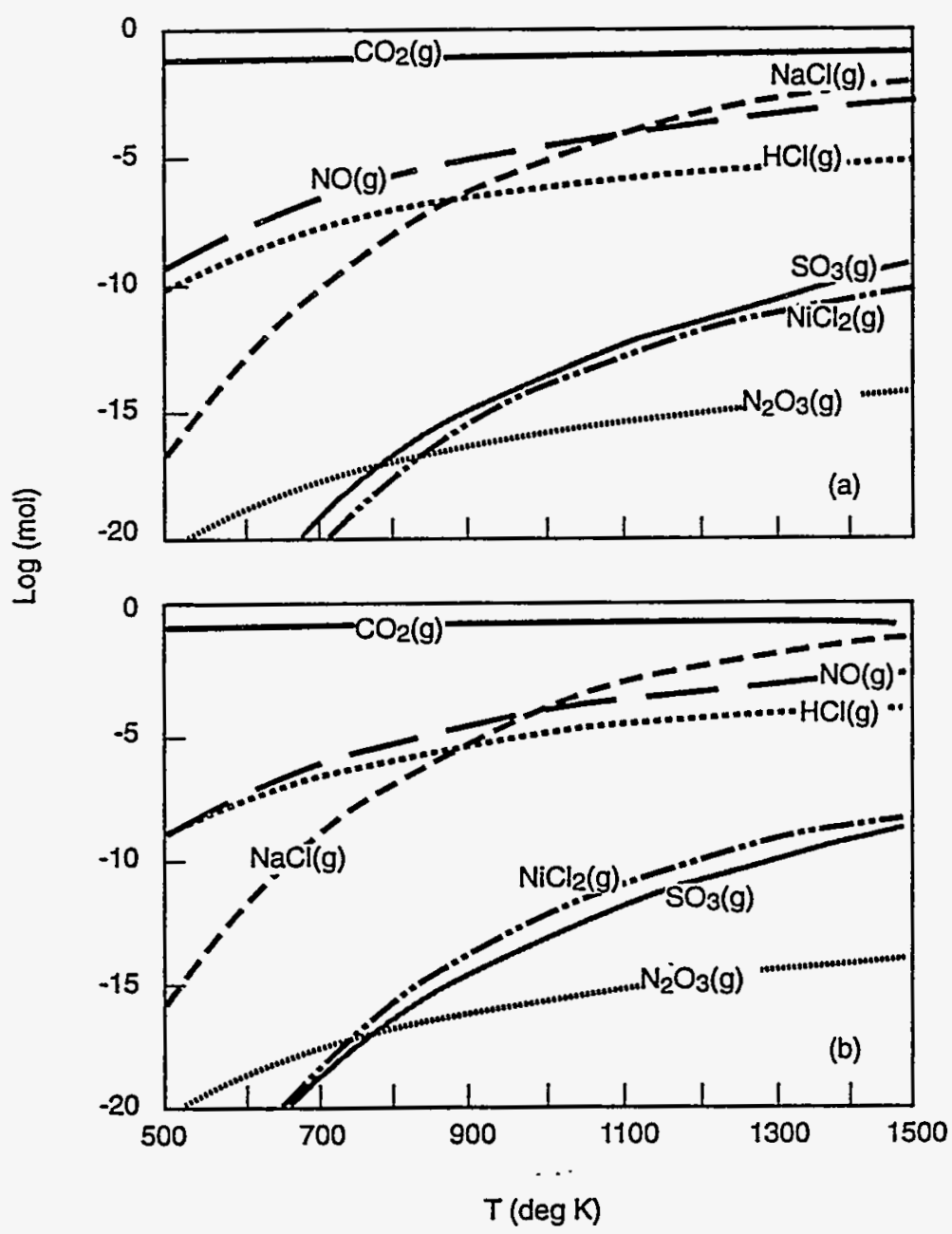

Feed Composition (mols)

$\begin{array}{llll} & & \text { Feed Comp } & \\ \mathrm{H}_{2} \mathrm{O} & 0.2 & \mathrm{NO}_{2} & 0.01 \\ \mathrm{O}_{2} & 0.1 & \mathrm{Na}_{2} \mathrm{CO}_{3} & 0.10 \\ \mathrm{CO}_{2} & 0.1 & \mathrm{Na}_{2} \mathrm{SO}_{4} & 0.01 \\ \mathrm{~N}_{2} & 0.6 & \mathrm{NiO} & 0.01 \\ \mathrm{SO}_{2} & 0.01 & \mathrm{HCl} & 0.01,0.05^{(\mathrm{a})}\end{array}$

FIGURE 8a,b. Calculated Equilibrium Concentrations, as a Function of Temperature $(500 \mathrm{~K}$ to $1500 \mathrm{~K})$, in Incinerator off-gas with $\mathrm{Ni}$ and $\mathrm{Na}$ Added to Initial Mixture and (a) $0.01 \mathrm{~mol}$ $\mathrm{HCl}$ and (b) $0.05 \mathrm{~mol} \mathrm{HCl}$ in Initial Feed (Test 2) 

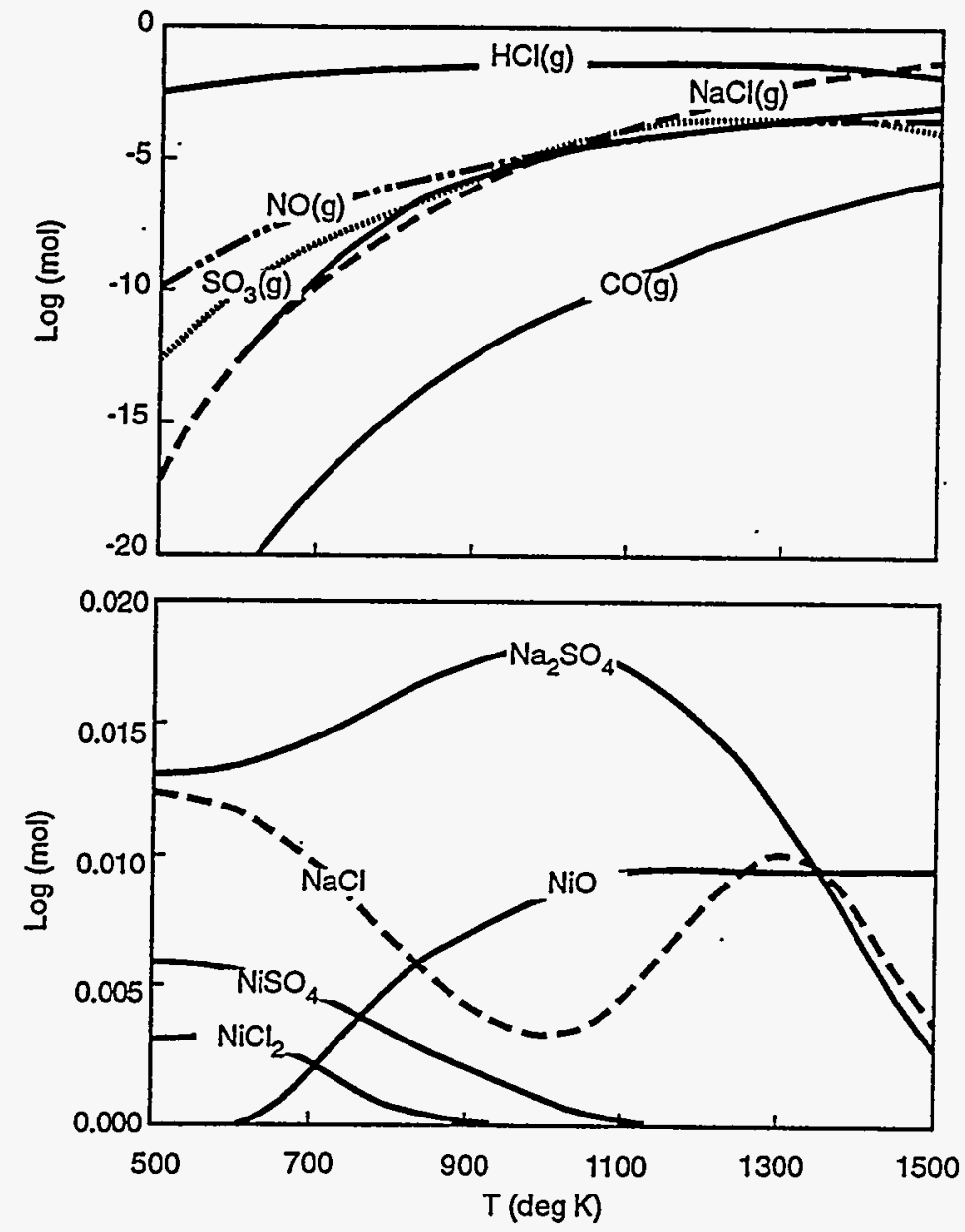

\begin{tabular}{llll}
\multicolumn{4}{c}{ Feed Composition (mols) } \\
\hline $\mathrm{H}_{2} \mathrm{O}$ & 0.2 & $\mathrm{SO}_{2}$ & 0.01 \\
$\mathrm{O}_{2}$ & 0.1 & $\mathrm{HCl}$ & 0.05 \\
$\mathrm{CO}_{2}$ & 0.1 & $\mathrm{Na}_{2} \mathrm{CO}_{3}$ & 0.01 \\
$\mathrm{~N}_{2}$ & 0.6 & $\mathrm{Na}_{2} \mathrm{SO}_{4}$ & 0.01 \\
$\mathrm{NO}_{2}$ & 0.01 & $\mathrm{NiO}_{4}$ & 0.01
\end{tabular}

FIGURE 8c,d. Calculated Equilibrium Concentrations, as a Function of Temperature $(500 \mathrm{~K}$ to $1500 \mathrm{~K})$, in Incinerator Off-Gas with $\mathrm{Ni}$ and $\mathrm{Na}$ Added to Initial Mixture and with Increased $\mathrm{HCl}(0.05 \mathrm{~mol})$ and Reduced $\mathrm{Na}_{2} \mathrm{CO}_{3}$ (from 0.1 to $0.01 \mathrm{~mol}$ ) 


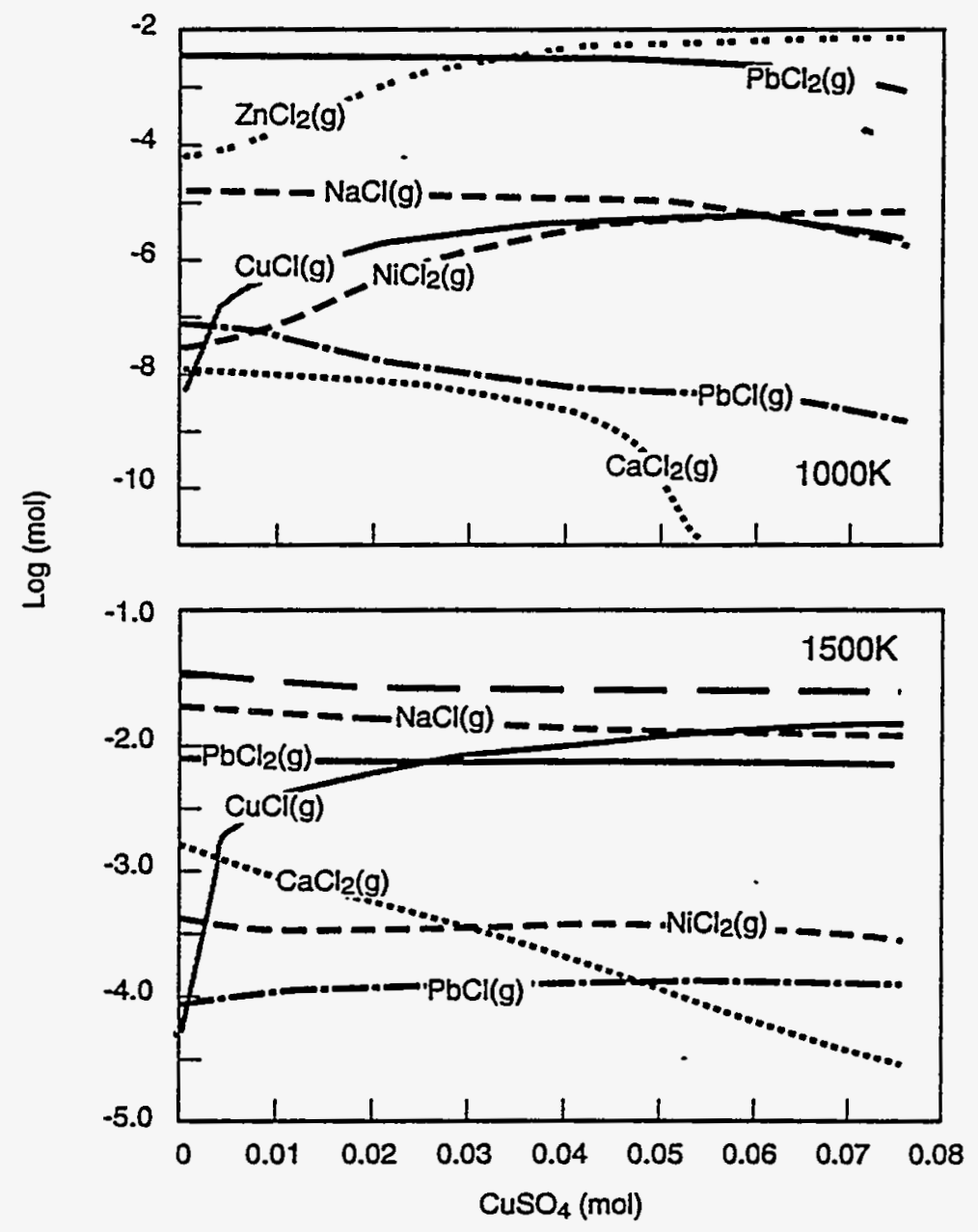

\section{Feed Composition (mols)}

\begin{tabular}{llll}
\hline $\mathrm{H}_{2} \mathrm{O}$ & 0.1 & $\mathrm{CaCl}_{2}$ & 0.05 \\
$\mathrm{O}_{2}$ & 0.1 & $\mathrm{CaO}$ & 0.03 \\
$\mathrm{CO}_{2}$ & 0.1 & $\mathrm{NiO}$ & 0.01 \\
$\mathrm{~N}_{2}$ & 0.6 & $\mathrm{CuO}$ & 0.01 \\
$\mathrm{NO}_{2}$ & 0.02 & $\mathrm{ZnO}$ & 0.01 \\
$\mathrm{HCl}$ & 0.02 & $\mathrm{PbO}$ & 0.01 \\
$\mathrm{NaOH}$ & 0.02 & $\mathrm{CuSO}_{4}$ & $0.0001-0.08$
\end{tabular}

FIGURE 9a,b. Calculated Equilibrium Concentrations, as a Function of Added $\mathrm{CuSO}_{4}$ (Test 3) in Incinerator Off-Gas: Gaseous Chlorides of $\mathrm{Na}, \mathrm{Ca}, \mathrm{Ni}, \mathrm{Cu}, \mathrm{Zn}$, and $\mathrm{Pb}$ at Temperatures (a) $1000 \mathrm{~K}$ and (b) $1500 \mathrm{~K}$ 


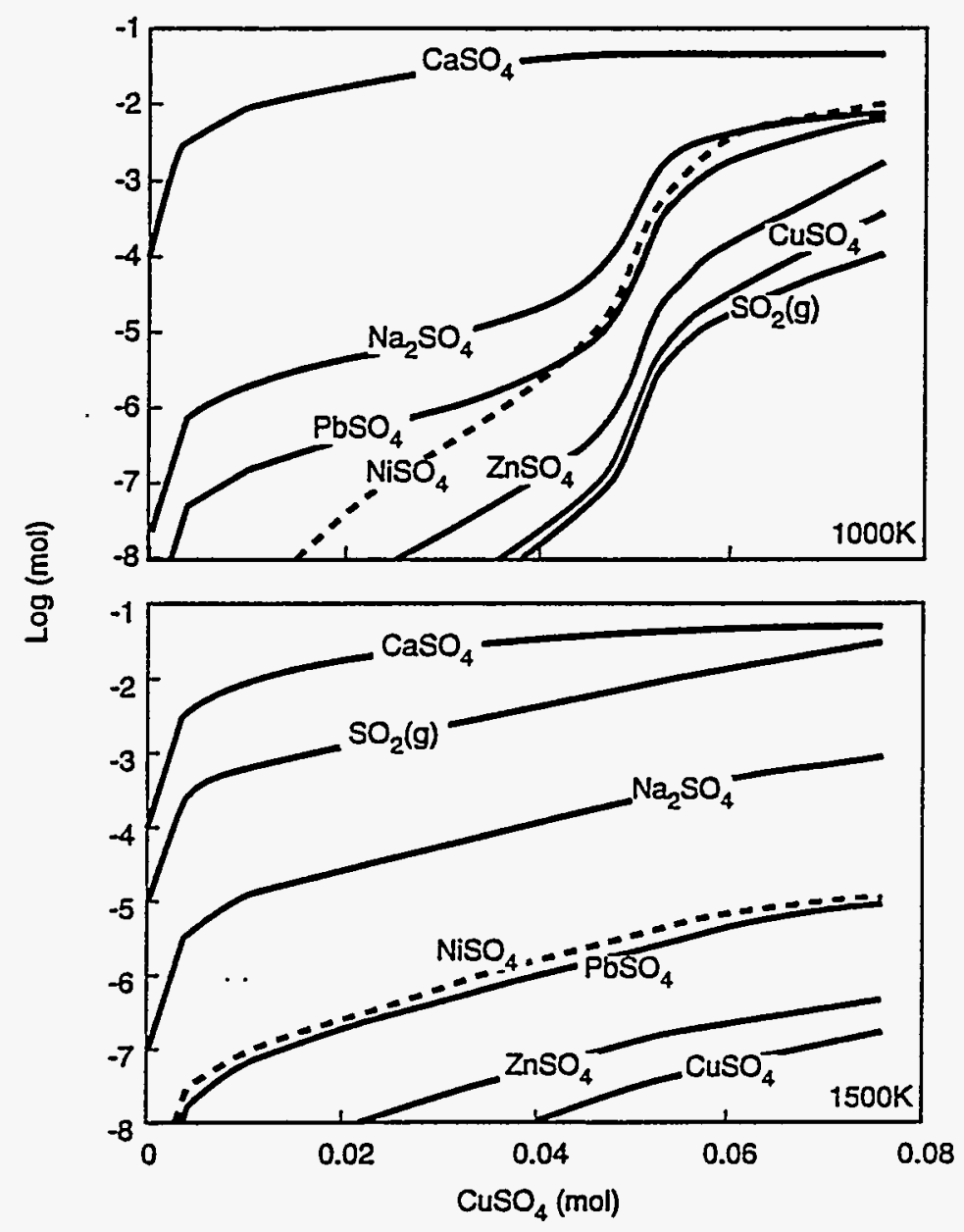

\begin{tabular}{llll} 
& \multicolumn{3}{c}{ Feed Composition (mols) } \\
\hline $\mathrm{H}_{2} \mathrm{O}$ & 0.1 & $\mathrm{CaCl}_{2}$ & 0.05 \\
$\mathrm{O}_{2}$ & 0.1 & $\mathrm{CaO}$ & 0.03 \\
$\mathrm{CO}_{2}$ & 0.1 & $\mathrm{NiO}$ & 0.01 \\
$\mathrm{~N}_{2}$ & 0.6 & $\mathrm{CuO}$ & 0.01 \\
$\mathrm{NO}_{2}$ & 0.02 & $\mathrm{ZnO}$ & 0.01 \\
$\mathrm{HC1}$ & 0.02 & $\mathrm{PbO}$ & 0.01 \\
$\mathrm{NaOH}$ & 0.02 & $\mathrm{CuSO}_{4}$ & $0.0001-0.08$
\end{tabular}

FIGURE 9c,d. Calculated Equilibrium Concentrations, as a Function of Added $\mathrm{CuSO}_{4}$, of Condensed Phase Products in an Incinerator: Sulfates of $\mathrm{Na}, \mathrm{Ca}, \mathrm{Ni}, \mathrm{Cu}, \mathrm{Zn}$, and $\mathrm{Pb}$ at Temperatures (c) $1000 \mathrm{~K}$ and (d) $1500 \mathrm{~K}$ 


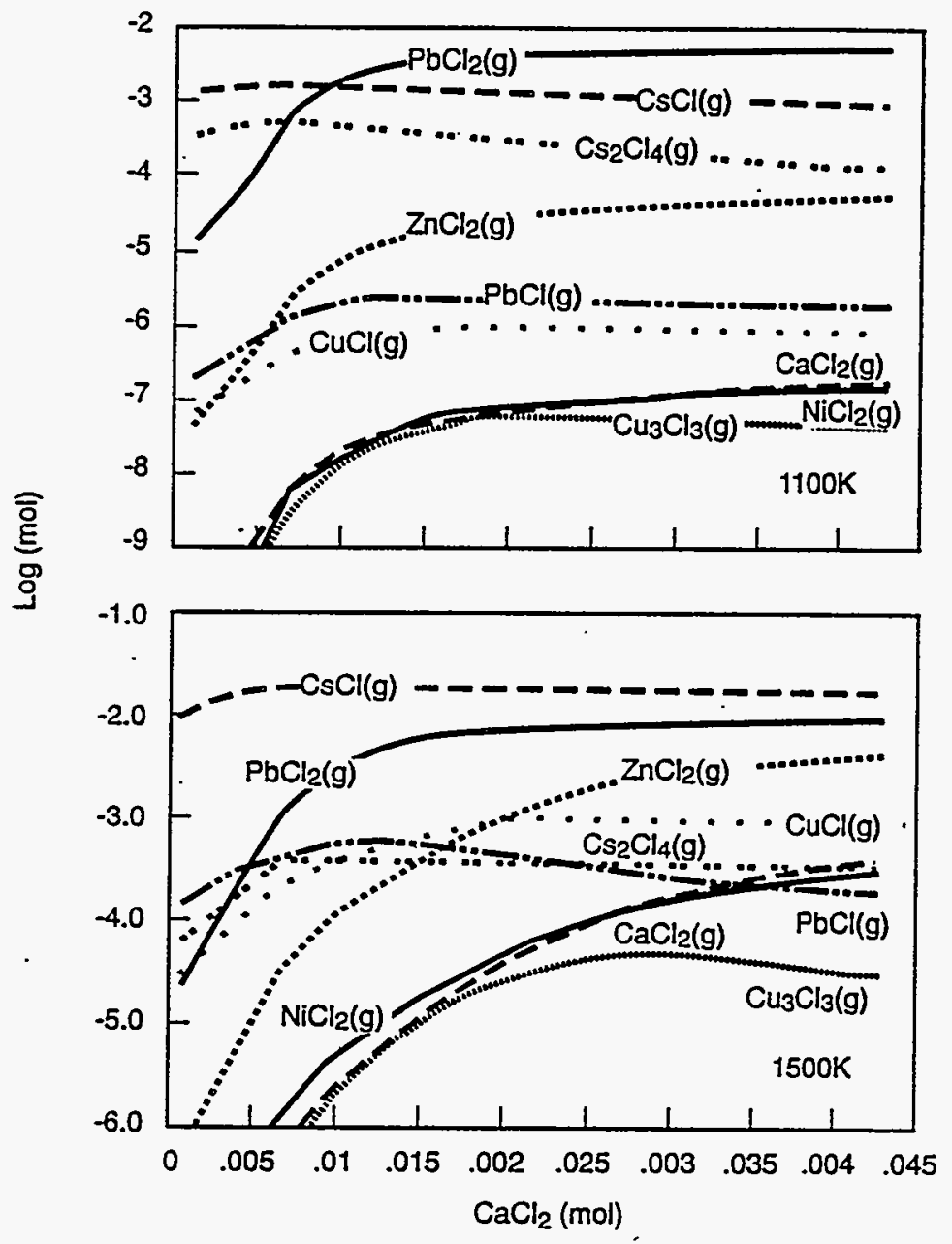

Feed Composition (mols)

\begin{tabular}{llll}
\hline $\mathrm{H}_{2} \mathrm{O}$ & 0.10 & $\mathrm{CaO}$ & 0.01 \\
$\mathrm{O}_{2}$ & 0.10 & $\mathrm{NiO}$ & 0.01 \\
$\mathrm{CO}_{2}$ & 0.10 & $\mathrm{CuO}$ & 0.01 \\
$\mathrm{~N}_{2}$ & 0.40 & $\mathrm{ZnO}$ & 0.01 \\
$\mathrm{SO}_{2}$ & 0.01 & $\mathrm{PbO}$ & 0.01 \\
$\mathrm{CsOH}$ & 0.02 & $\mathrm{CaCl}$ & $0.001-0.045$
\end{tabular}

FIGURE 10a,b. Calculated Equilibrium Concentrations, as a Function of Added $\mathrm{CaCl}_{2}$ (Test 4), in Incinerator Off-Gas: Gaseous Chtorides of $\mathrm{Cs}, \mathrm{Ca}, \mathrm{Ni}, \mathrm{Cu}, \mathrm{Zn}$, and $\mathrm{Pb}$ at Temperatures (a) $1100 \mathrm{~K}$ and (b) $1500 \mathrm{~K}$ 


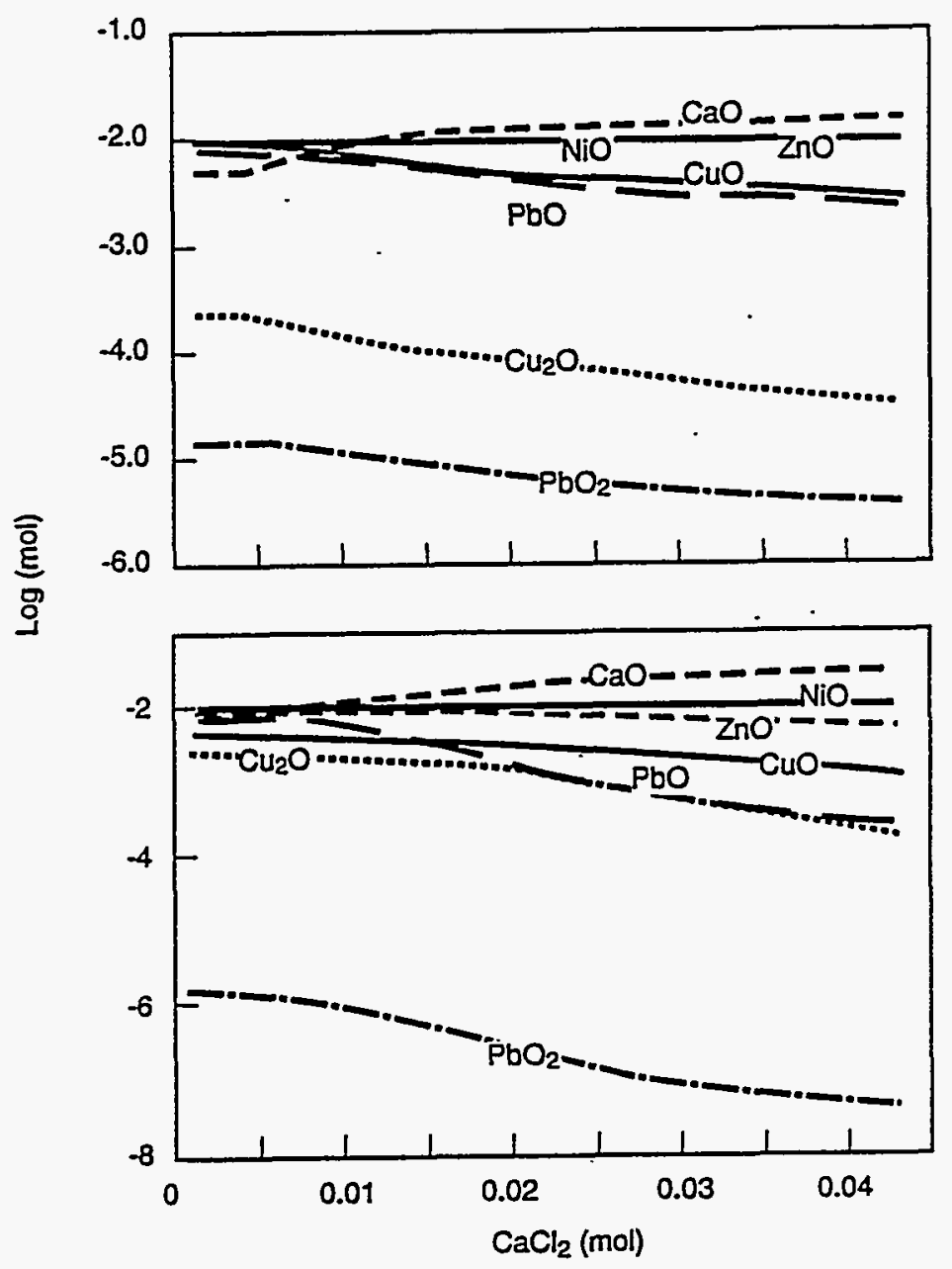

Feed Composition (mols)

\begin{tabular}{llll}
\hline $\mathrm{H}_{2} \mathrm{O}$ & 0.10 & $\mathrm{CaO}$ & 0.01 \\
$\mathrm{O}_{2}$ & 0.10 & $\mathrm{NiO}$ & 0.01 \\
$\mathrm{CO}_{2}$ & 0.10 & $\mathrm{CuO}$ & 0.01 \\
$\mathrm{~N}_{2}$ & 0.40 & $\mathrm{ZnO}$ & 0.01 \\
$\mathrm{SO}_{2}$ & 0.01 & $\mathrm{PbO}$ & 0.01 \\
$\mathrm{CsOH}$ & 0.02 & $\mathrm{CaCl}$ & $0.001-0.045$
\end{tabular}

FIGURE 10c,d. Calculated Equilibrium Concentrations, as a Function of Added $\mathrm{CaCl}_{2}$, of Condensed Phase Products in an Incinerator: $0 x i d e s$ of $\mathrm{Ca}, \mathrm{Ni}, \mathrm{Cu}, \mathrm{Zn}$, and $\mathrm{Pb}$ at Temperatures at. (c) $1100 \mathrm{~K}$ and (d) $1500 \mathrm{~K}$ 


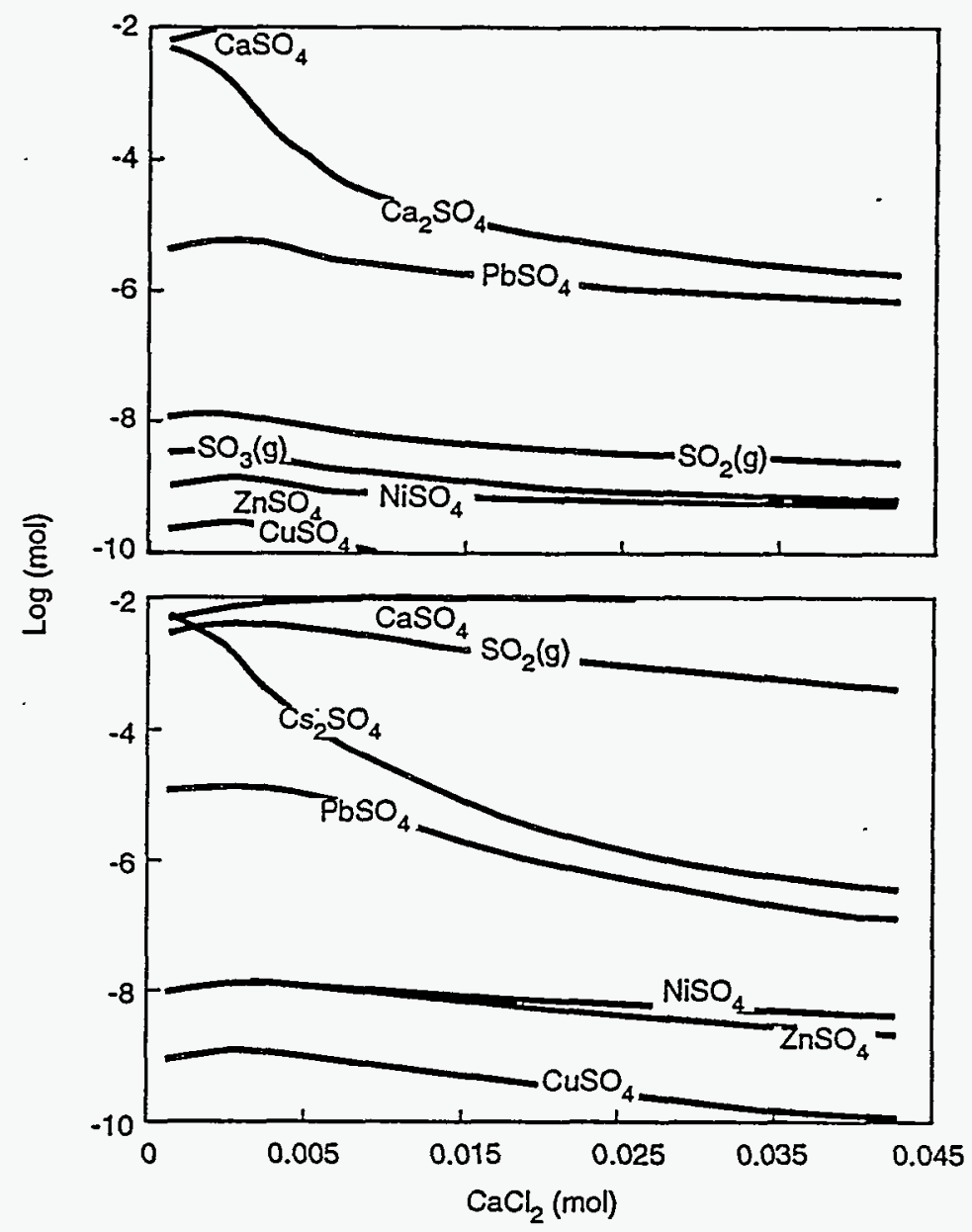

Feed Composition (mols)

\begin{tabular}{llll}
\hline $\mathrm{H}_{2} \mathrm{O}$ & 0.10 & $\mathrm{CaO}$ & 0.01 \\
$\mathrm{O}_{2}$ & 0.10 & $\mathrm{NiO}$ & 0.01 \\
$\mathrm{CO}_{2}$ & 0.10 & $\mathrm{CuO}$ & 0.01 \\
$\mathrm{~N}_{2}$ & 0.40 & $\mathrm{ZnO}$ & 0.01 \\
$\mathrm{SO}_{2}$ & 0.01 & $\mathrm{PbO}$ & 0.01 \\
$\mathrm{CsOH}$ & 0.02 & $\mathrm{CaCl}_{2}$ & $0.001-0.045$
\end{tabular}

FIGURE 10e,f. Calculated Equilibrium Concentrations, as a Function of Added $\mathrm{CaCl}_{2}$, of Condensed Phase Products in an Incinerator: Sulfates of $\mathrm{Cs}, \mathrm{Ca}, \mathrm{Ni}, \mathrm{Cu}, \mathrm{Zn}$, and $\mathrm{Pb}$ at Temperatures (e) $1000 \mathrm{~K}$ and (f) $1500 \mathrm{~K}$ 


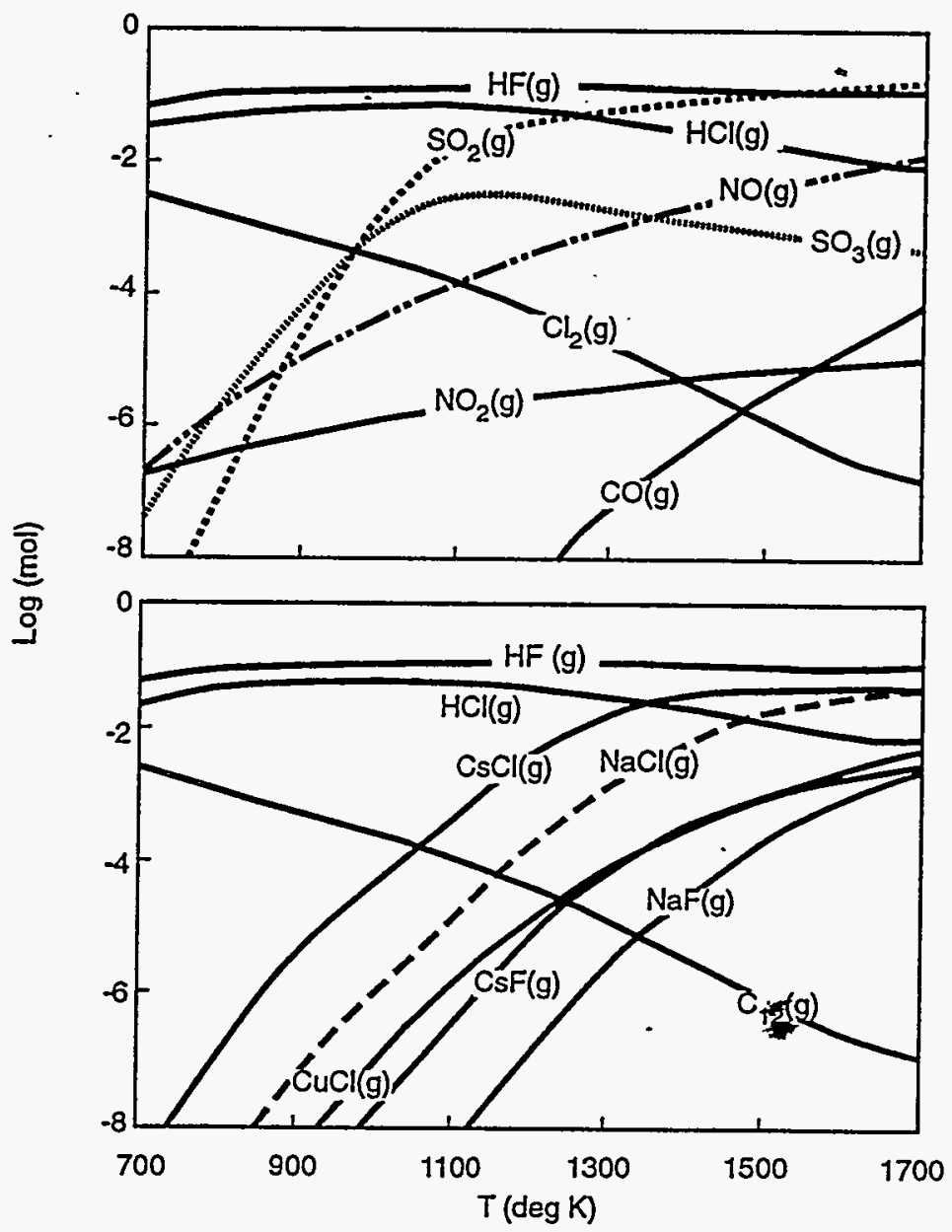

Feed Composition (mols)

\begin{tabular}{llll}
\hline $\mathrm{H}_{2} \mathrm{O}$ & 0.15 & $\mathrm{NaOH}$ & 0.01 \\
$\mathrm{O}_{2}$ & 0.10 & $\mathrm{CsOH}$ & 0.01 \\
$\mathrm{CO}_{2}$ & 0.10 & $\mathrm{CaO}$ & 0.005 \\
$\mathrm{~N}_{2}$ & 0.40 & $\mathrm{MnO}$ & 0.005 \\
$\mathrm{NO}_{2}$ & 0.02 & $\mathrm{FeO}$ & 0.005 \\
$\mathrm{SO}_{2}$ & 0.02 & $\mathrm{CoO}$ & 0.005 \\
$\mathrm{HC} 1$ & 0.02 & $\mathrm{CuO}$ & 0.005 \\
$\mathrm{HF}$ & 0.02 & $\mathrm{ZnO}$ & 0.005
\end{tabular}

FIGURE 11a,b. Calculated Equilibrium Concentrations, as a Function of Temperature ( $700 \mathrm{~K}$ to $1700 \mathrm{~K}$ ), in Incinerator Off-Gas of (a) S, N, and C Oxides and Acid Gases and (b) Chlorides and Fluorides of $\mathrm{Cs}, \mathrm{Na}$, and $\mathrm{Cu}$ (Test 5) 


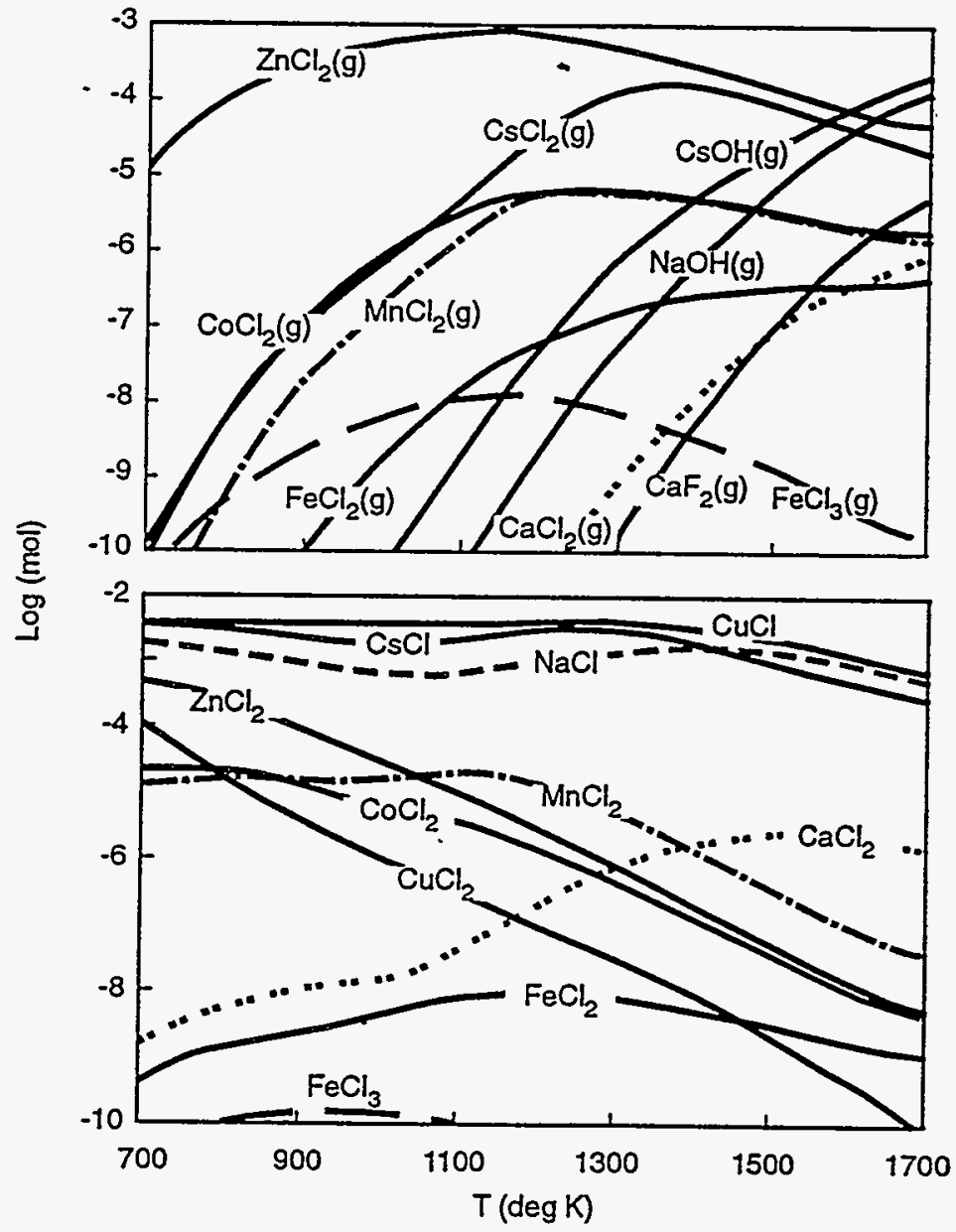

\begin{tabular}{llll} 
& \multicolumn{4}{c}{ Feed Composition (mols) } \\
\hline $\mathrm{H}_{2} \mathrm{O}$ & 0.15 & $\mathrm{NaOH}$ & 0.01 \\
$\mathrm{O}_{2}$ & 0.10 & $\mathrm{CsOH}$ & 0.01 \\
$\mathrm{CO}_{2}$ & 0.10 & $\mathrm{CaO}$ & 0.005 \\
$\mathrm{~N}_{2}$ & 0.40 & $\mathrm{MnO}$ & 0.005 \\
$\mathrm{NO}_{2}$ & 0.02 & $\mathrm{FeO}$ & 0.005 \\
$\mathrm{SO}_{2}$ & 0.02 & $\mathrm{CoO}$ & 0.005 \\
$\mathrm{HC1}$ & 0.02 & $\mathrm{CuO}$ & 0.005 \\
$\mathrm{HF}$ & 0.02 & $\mathrm{ZnO}$ & 0.005
\end{tabular}

FIGURE 1lc,d. Calculated Equilibrium Concentrations, as a Function of Temperature ( $700 \mathrm{~K}$ to $1700 \mathrm{~K}$ ), in Incinerator Off-Gas (Test 5) of (c) Chlorides, Fluorides, and Hydroxides of $\mathrm{Na}, \mathrm{Cs}, \mathrm{Ca}, \mathrm{Mn}, \mathrm{Fe}, \mathrm{Co}$, and $\mathrm{Zn}$ and (d) Condensed Phase Chlorides of $\mathrm{Na}, \mathrm{Cs}, \mathrm{Ca}, \mathrm{Mn}, \mathrm{Fe}, \mathrm{Co}, \mathrm{Cu}$, and $\mathrm{Zn}$ 


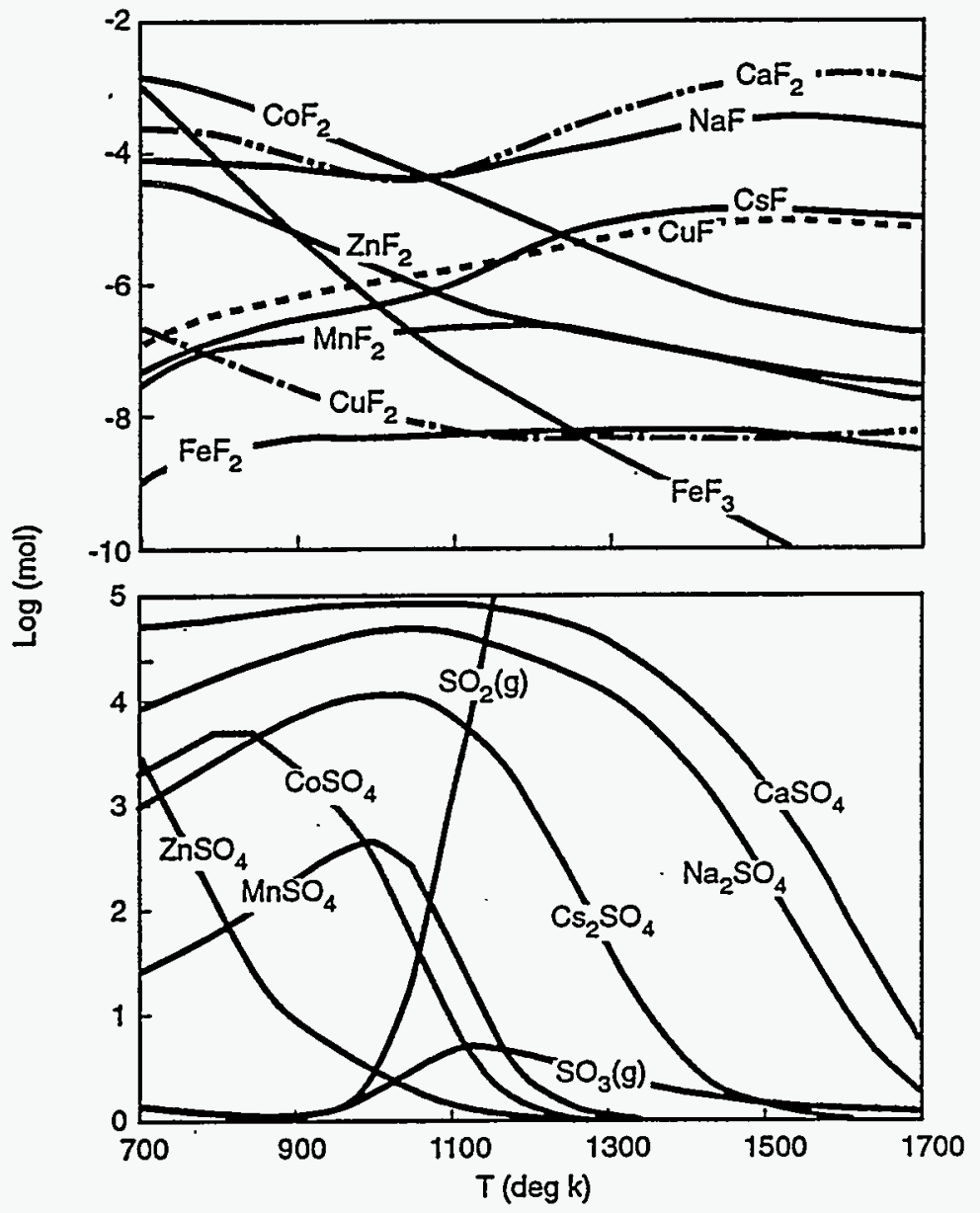

Feed Composition (mols)

\begin{tabular}{llll}
\hline $\mathrm{H}_{2} \mathrm{O}$ & 0.15 & $\mathrm{NaOh}$ & 0.01 \\
$\mathrm{O}_{2}$ & 0.10 & $\mathrm{C} 5 \mathrm{OH}$ & 0.01 \\
$\mathrm{CO}_{2}$ & 0.10 & $\mathrm{CaO}$ & 0.005 \\
$\mathrm{~N}_{2}$ & 0.40 & $\mathrm{MnO}$ & 0.005 \\
$\mathrm{NO}_{2}$ & 0.02 & $\mathrm{FeO}$ & 0.005 \\
$\mathrm{SO}_{2}$ & 0.02 & $\mathrm{CoO}$ & 0.005 \\
$\mathrm{HC} 1$ & 0.02 & $\mathrm{CuO}$ & 0.005 \\
$\mathrm{~F}$ & 0.02 & $\mathrm{ZnO}$ & 0.005
\end{tabular}

FIGURE 1le,f. Calculated Equilibrium Concentrations, as a Function of Temperature ( $700 \mathrm{~K}$ to $1700 \mathrm{~K}$ ) in an Incinerator (Test 5) of (e) Condensed Phase Fluorides of $\mathrm{Na}, \mathrm{Cs}$, $\mathrm{Ca}, \mathrm{Mn}, \mathrm{Fe}, \mathrm{Co}, \mathrm{Cu}$, and $\mathrm{Zn}$ and ( $\mathrm{f}$ ) Condensed Phase Sulfates of $\mathrm{Na}, \mathrm{Cs}, \mathrm{Ca}, \mathrm{Mn}, \mathrm{Co}$, and $\mathrm{Zn}$ 

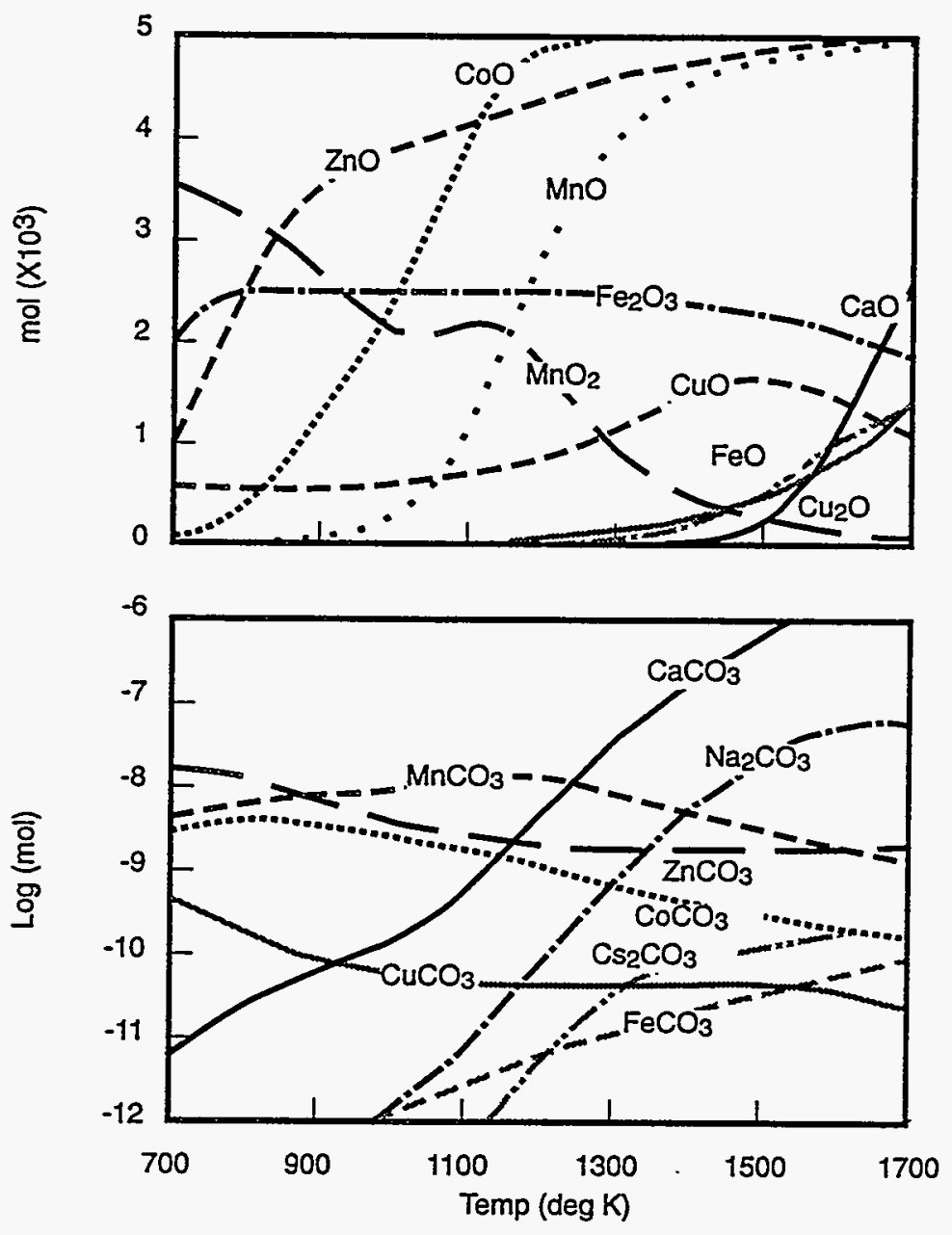

Feed Composition (mols)

\begin{tabular}{llll}
\hline $\mathrm{H}_{2} \mathrm{O}$ & 0.15 & $\mathrm{NaOH}$ & 0.01 \\
$\mathrm{O}_{2}$ & 0.10 & $\mathrm{CsOH}$ & 0.01 \\
$\mathrm{CO}_{2}$ & 0.10 & $\mathrm{CaO}$ & 0.005 \\
$\mathrm{~N}_{2}$ & 0.40 & $\mathrm{MnO}$ & 0.005 \\
$\mathrm{NO}_{2}$ & 0.02 & $\mathrm{FeO}$ & 0.005 \\
$\mathrm{SO}_{2}$ & 0.02 & $\mathrm{CoO}$ & 0.005 \\
$\mathrm{HC} 1$ & 0.02 & $\mathrm{CuO}$ & 0.005 \\
$\mathrm{HF}$ & 0.02 & $\mathrm{ZnO}$ & 0.005
\end{tabular}

FIGURE 1lg,h. Calculated Equilibrium Concentrations, as a Function of Temperature (700 K to $1700 \mathrm{~K}$ ) in Incinerator Off-Gas (Test 5) of (g) Condensed Phase Oxides of $\mathrm{Ca}, \mathrm{Mn}, \mathrm{Fe}, \mathrm{Co}, \mathrm{Cu}$, and $\mathrm{Zn}$ and $(\mathrm{h})$ Condensed Phase Carbonates of $\mathrm{Na}, \mathrm{Cs}, \mathrm{Ca}, \mathrm{Mn}, \mathrm{Co}$, and $\mathrm{Zn}$ 


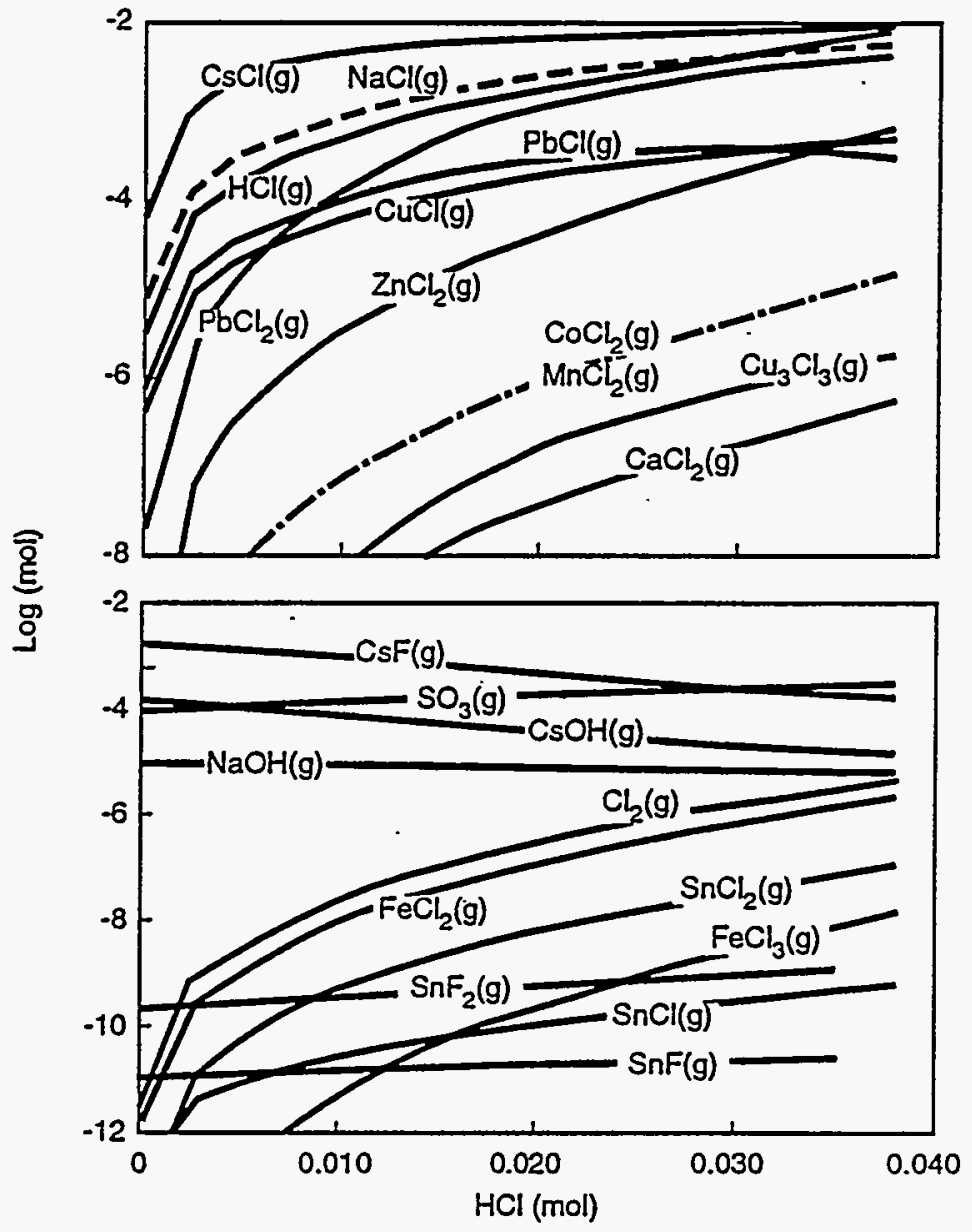

Feed Composition (mols)

\begin{tabular}{llll}
\hline $\mathrm{H}_{2} \mathrm{O}$ & 0.15 & $\mathrm{CaO}$ & 0.005 \\
$\mathrm{O}_{2}$ & 0.10 & $\mathrm{MnO}$ & 0.005 \\
$\mathrm{CO}_{2}$ & 0.10 & $\mathrm{FeO}$ & 0.005 \\
$\mathrm{~N}_{2}$ & 0.40 & $\mathrm{CoO}$ & 0.005 \\
$\mathrm{NO}_{2}$ & 0.02 & $\mathrm{CuO}$ & 0.005 \\
$\mathrm{SO}_{2}$ & 0.02 & $\mathrm{ZnO}$ & 0.005 \\
$\mathrm{HF}^{2}$ & 0.02 & $\mathrm{SnO}$ & 0.005 \\
$\mathrm{NaOH}$ & 0.01 & $\mathrm{PbO}$ & 0.005 \\
$\mathrm{CsOH}$ & 0.01 & $\mathrm{HCT}$ & $0.0002-0.04$
\end{tabular}

FIGURE 12a,b. Calculated Equilibrium Concentrations, as a Function of $\mathrm{HCl}$ Feed, in Incinerator Off-Gas at Temperature $1500 \mathrm{~K}$ (Test 6), Showing the $\mathrm{HCl}$ Effect on Volatility of (a) Chlorides of $\mathrm{Na}$, $\mathrm{Cs}, \mathrm{Ca}, \mathrm{Mn}, \mathrm{Co}, \mathrm{Cu}, \mathrm{Zn}$, and $\mathrm{Pb}$ and (b) Fluorides, Chlorides, and Hydroxides of $\mathrm{Na}, \mathrm{Cs}, \mathrm{Fe}$, and $\mathrm{Sn}$ 


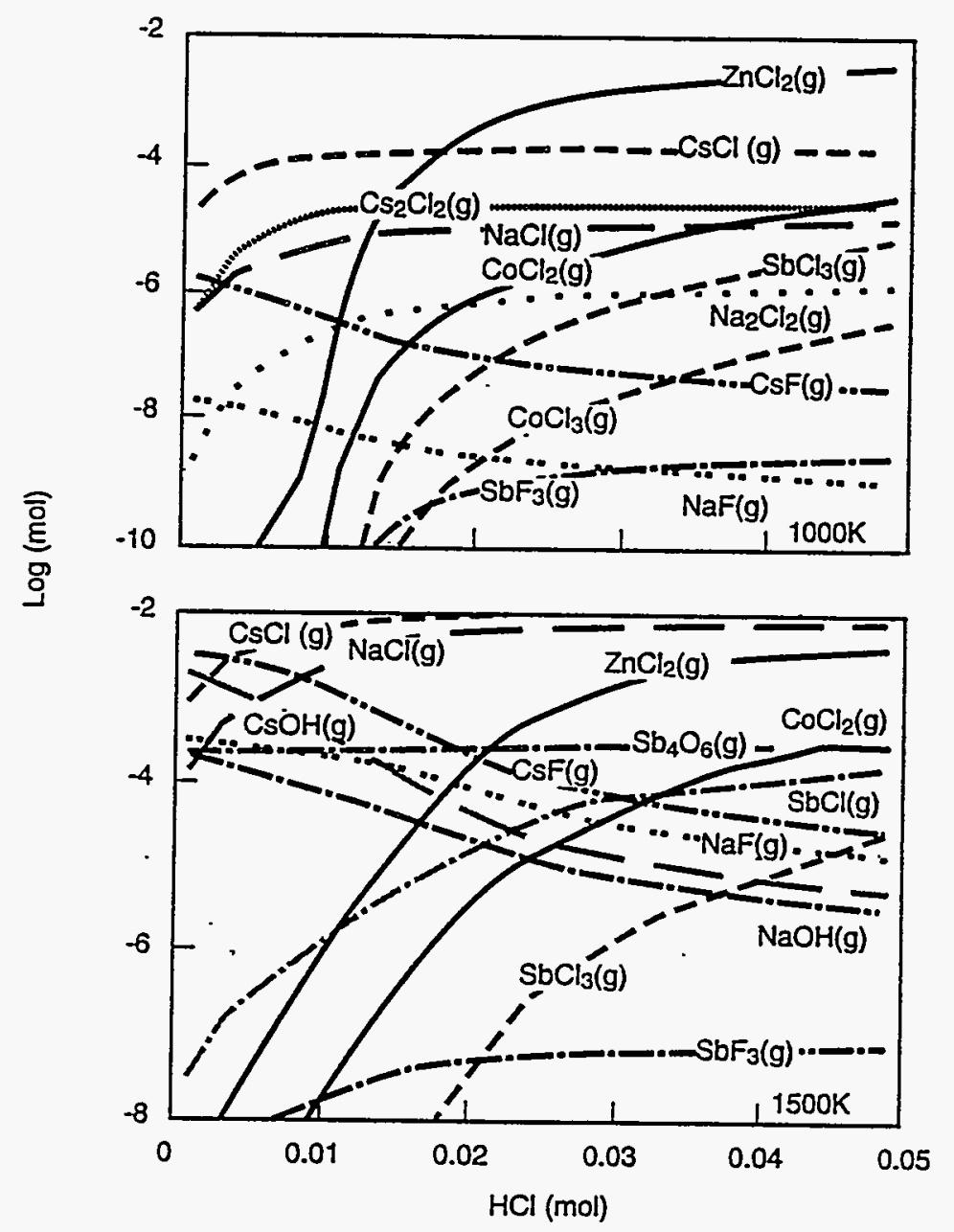

Feed Composition (mols)

\begin{tabular}{llll}
\hline $\mathrm{H}_{2} \mathrm{O}$ & 0.15 & $\mathrm{Cs}_{2} \mathrm{CO}_{3}$ & 0.005 \\
$\mathrm{O}_{2}$ & 0.10 & $\mathrm{CaO}$ & 0.005 \\
$\mathrm{CO}_{2}$ & 0.10 & $\mathrm{Sr} 0$ & 0.005 \\
$\mathrm{~N}_{2}$ & 0.60 & $\mathrm{CoO}$ & 0.005 \\
$\mathrm{NO}_{2}$ & 0.02 & $\mathrm{ZnO}$ & 0.005 \\
$\mathrm{SO}_{2}$ & 0.01 & $\mathrm{ZrO}_{2}$ & 0.005 \\
$\mathrm{HF}^{2}$ & 0.01 & $\mathrm{SbO}_{2}$ & 0.005 \\
$\mathrm{Na}_{2} \mathrm{CO}_{3}$ & 0.005 & $\mathrm{HCl}^{2}$ & $0.001-0.05$
\end{tabular}

FIGURE 13a,b. Calculated Equilibrium Concentrations, as a Function of $\mathrm{HCl}$ Feed, in Incinerator Off-Gas (Test 7), Showing the $\mathrm{HCl}$ Effect on Volatility of $\mathrm{Na}, \mathrm{Cs}, \mathrm{Co}, \mathrm{Zn}$, and $\mathrm{Sb}$ at Temperatures (a) $1000 \mathrm{~K}$ and (b) $1500 \mathrm{~K}$ 

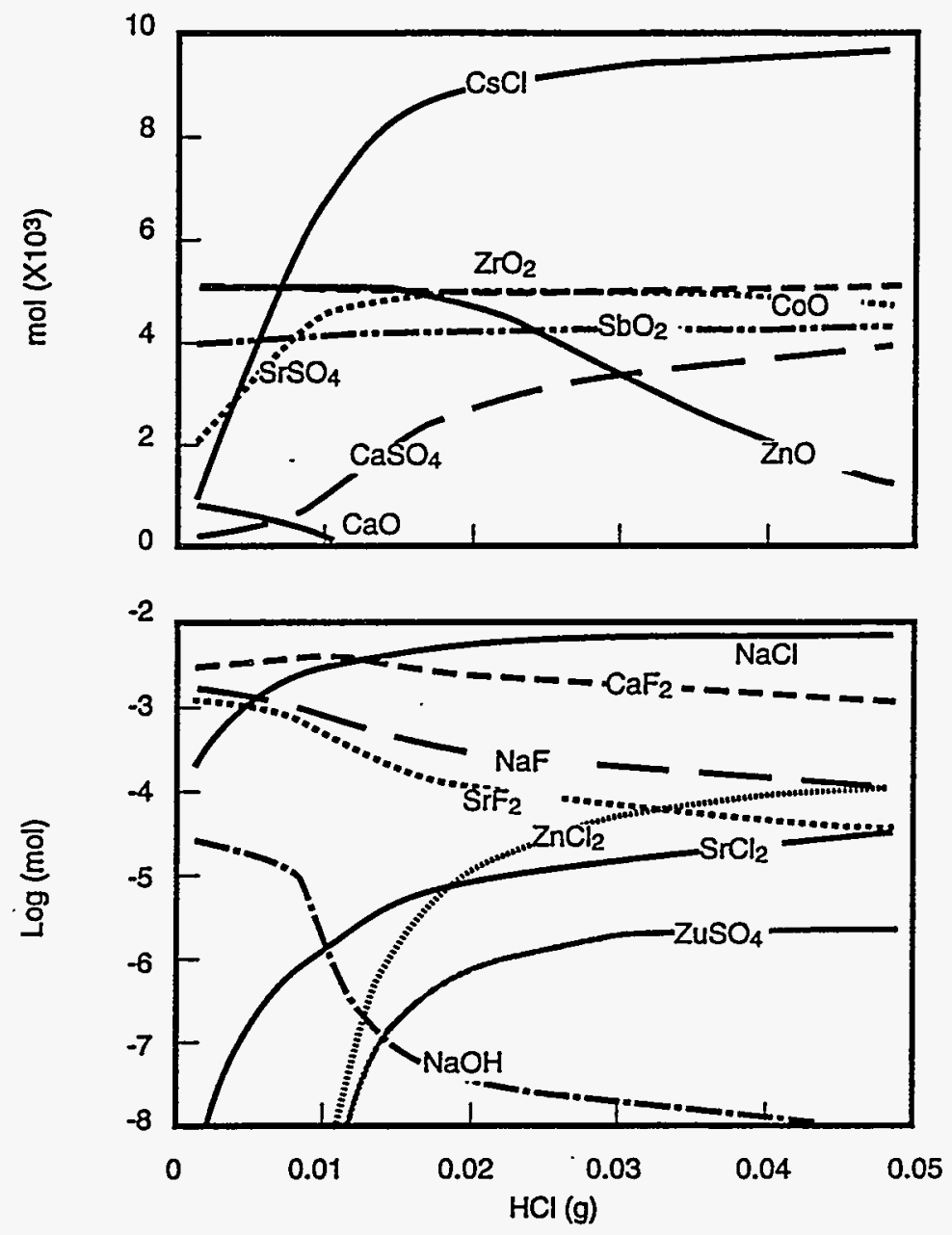

Feed Composition (mols)

\begin{tabular}{llll}
\hline $\mathrm{H}_{2} \mathrm{O}$ & 0.15 & $\mathrm{Cs}_{2} \mathrm{CO}_{3}$ & 0.005 \\
$\mathrm{O}_{2}$ & 0.10 & $\mathrm{CaO}$ & 0.005 \\
$\mathrm{CO}_{2}$ & 0.10 & $\mathrm{SrO}$ & 0.005 \\
$\mathrm{~N}_{2}$ & 0.60 & $\mathrm{CoO}$ & 0.005 \\
$\mathrm{NO}_{2}$ & 0.02 & $\mathrm{ZnO}$ & 0.005 \\
$\mathrm{SO}_{2}$ & 0.01 & $\mathrm{ZrO}_{2}$ & 0.005 \\
$\mathrm{HF}^{2}$ & 0.01 & $\mathrm{SbO}_{2}$ & 0.005 \\
$\mathrm{Na}_{2} \mathrm{CO}_{3}$ & 0.005 & $\mathrm{HCl}^{2}$ & $0.001-0.05$
\end{tabular}

FIGURE 13c,d. Calculated Equilibrium Concentrations, as a Function of $\mathrm{HCl}$ Feed, in Condensed Phase Products in an Incinerator (Test 7), Showing the Effect of $\mathrm{HCl}$ Concentration on Metal Oxides and Salts at $1000 \mathrm{~K}$ for (c) Cs, Ca, Sr, Co, Zn, Zr, and $\mathrm{Sb}$; and (d) $\mathrm{Na}, \mathrm{Ca}, \mathrm{Sr}, \mathrm{Zn}$ 


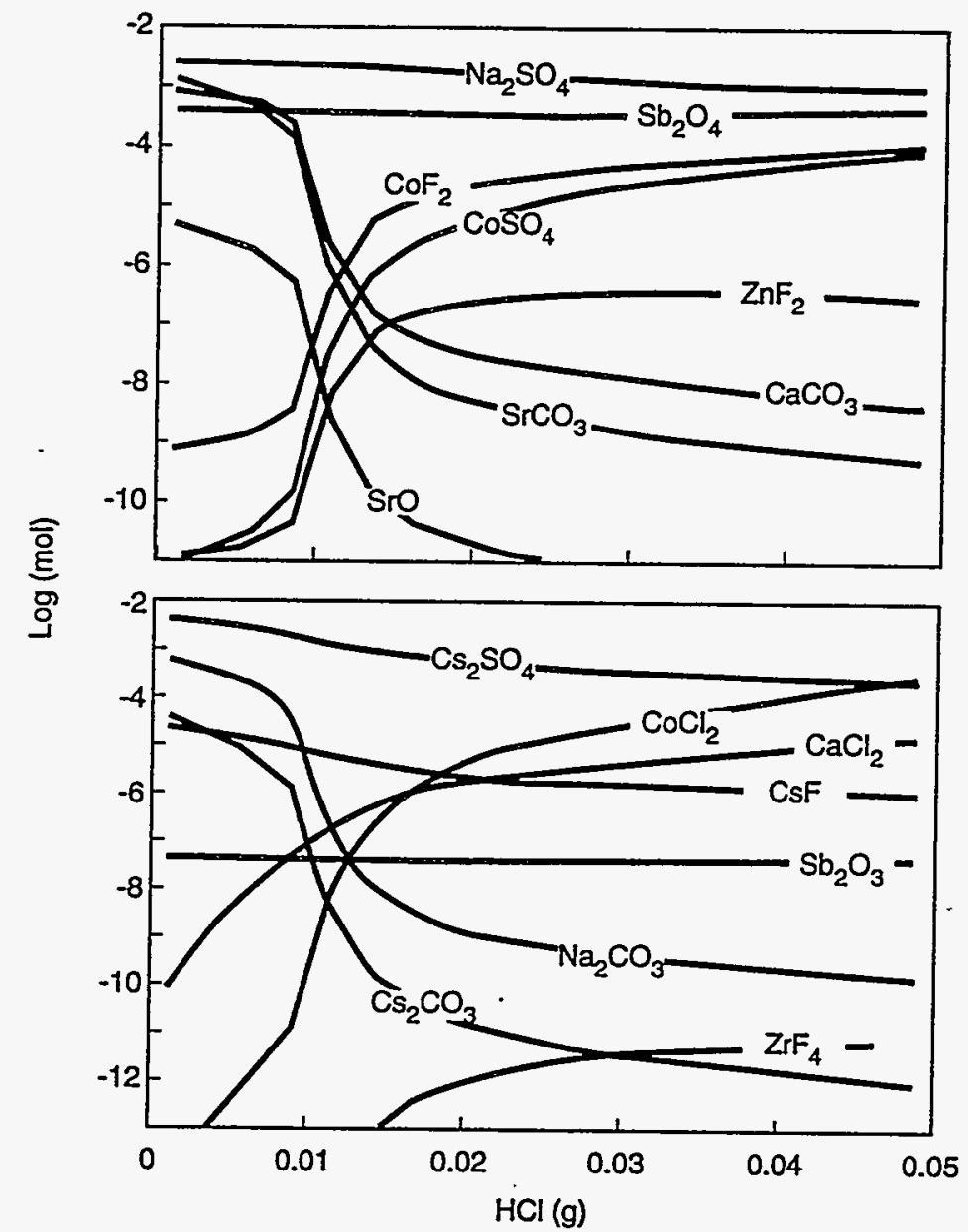

Feed Composition (mols)

\begin{tabular}{llll}
\hline $\mathrm{H}_{2} \mathrm{O}$ & 0.15 & $\mathrm{Cs}_{2} \mathrm{CO}_{3}$ & 0.005 \\
$\mathrm{O}_{2}$ & 0.10 & $\mathrm{CaO}$ & 0.005 \\
$\mathrm{CO}_{2}$ & 0.10 & $\mathrm{SrO}$ & 0.005 \\
$\mathrm{~N}_{2}$ & 0.60 & $\mathrm{CoO}$ & 0.005 \\
$\mathrm{NO}_{2}$ & 0.02 & $\mathrm{ZnO}$ & 0.005 \\
$\mathrm{SO}_{2}$ & 0.01 & $\mathrm{ZrO}_{2}$ & 0.005 \\
$\mathrm{HF}^{2}$ & 0.01 & $\mathrm{SbO}_{2}$ & 0.005. \\
$\mathrm{Na}_{2} \mathrm{CO}_{3}$ & 0.005 & $\mathrm{HCT}^{2}$ & $0.001-0.05$
\end{tabular}

FIGURE 13e,f. Calculated Equilibrium Concentrations, as a Function of $\mathrm{HCl}$ Feed, in Condensed Phase Products in an Incinerator (Test 7), Showing the Effect of $\mathrm{HCl}$ Concentration on Metal Vaporization at $1000 \mathrm{~K}$ for (e) $\mathrm{Na}, \mathrm{Ca}, \mathrm{Sr}, \mathrm{Co}, \mathrm{Zn}$, and $\mathrm{Sb}$; and (f) $\mathrm{Na}, \mathrm{Cs}, \mathrm{Ca}, \mathrm{Co}, \mathrm{Zr}$, and $\mathrm{Sb}$ 
begins to decompose as the temperature reaches about $1000 \mathrm{~K}$ and NiO becomes the dominant species.

Another simulation is to observe the effects of adding one component incrementally while holding the temperature constant. Using the compositions of Test 3, CuSO $_{4}$ was added in 20 increments of 0.004 mols each. Copper sulfate is relatively unstable and the effect should be that of adding $\mathrm{SO}_{3}$ to the mixture $\left(\mathrm{H}_{2} \mathrm{SO}_{4}\right.$ at low temperatures and $\mathrm{SO}_{2}$ at high temperatures). Calculations were made at $1000 \mathrm{~K}$ and $1500 \mathrm{~K}$ with 0.02 mols $\mathrm{HCl}$ present. This mixture includes the metals $\mathrm{Ni}, \mathrm{Zn}$, and $\mathrm{Pb}$, along with the $\mathrm{Na}$ and $\mathrm{Cu}$. The gaseous data at $1000 \mathrm{~K}$ and $1500 \mathrm{~K}$ are shown in Figures $9 \mathrm{a}$ and $9 \mathrm{~b}$, respectively.

Several features can be noted. The increasing acidity as the sulfate is added increases the partial pressures of those metal chlorides that have low or moderate metal sulfate stability, e.g., Zn. Lead sulfate is more stable, and both it and sodium show a lowered partial pressure, but most significantly only after sufficient sulfate has been added to completely remove the calcium. The principal driving force for volatilization in this high chloride mixture appears to be the volatility of the metal chlorides. $\mathrm{PbCl}_{2}$ and $\mathrm{ZnCl}_{2}$ are both very volatile; $\mathrm{Pb}$, having the more stable sulfate, drops below $\mathrm{Zn}$ at the highest $\mathrm{SO}_{4}$ levels. At $1500 \mathrm{~K}$ all the sulfates except $\mathrm{CaSO}_{4}$ are sufficiently unstable that there is little effect from the sulfate addition. The calculated volatility of $\mathrm{NaCl}$ is higher than expected.

Rajsing the temperature from $1000 \mathrm{~K}$ to $1500 \mathrm{~K}$ changes the volatility order, $\mathrm{NaCl}$ replacing $\mathrm{PbCl}_{2}$ and $\mathrm{CuCl}$ replacing $\mathrm{ZnCl}_{2}$. The computed partial pressures of the different chlorides are not always in the same order as the vapor pressures of the pure compounds, the stability of the chlorides, nor, inversely, as the stability of the sulfates. This illustrates the need to consider the free energy (stability) of each specie; in the present system these are primarity the chlorides, sulfates, oxides, and carbonates of each of the metals, and occasionally the fluorides. 
The relative sulfate concentrations in the condensed phase are shown in

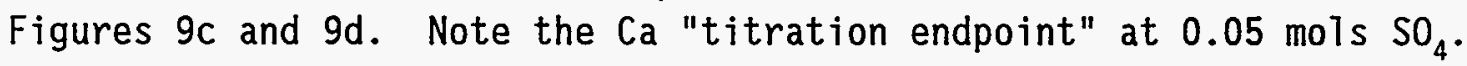

In contrast to sulfate, the stepwise addition of $\mathrm{CaCl}_{2}$ should have a positive effect on the volatility of most metals. The stability of $\mathrm{CaCl}_{2}$ is intermediate, as can be seen from Figure 3. However, the stability of $\mathrm{CaSO}_{4}$ is great enough that if sulfur is present, $\mathrm{CaCl}_{2}$ should become a good chlorinating agent. For example, for the reaction

$$
\mathrm{CaCl}_{2}+\mathrm{ZnSO}_{4} \rightleftarrows \mathrm{CaSO}_{4}+\mathrm{ZnCl}_{2}
$$

the free energy (condensed phases) is $-82 \mathrm{~kJ}$ at $1000 \mathrm{~K}$, even though $\mathrm{CaCl}_{2}$ is more stable than $\mathrm{ZnCl}_{2}$. Corresponding data at $1000 \mathrm{~K}$ for $\mathrm{Ni}, \mathrm{Co}, \mathrm{Cu}(\mathrm{II})$, and $2 \mathrm{Cs}$ are $-64,-64,-71$, and $-75 \mathrm{~kJ}$.

Figures 10a and 10b show the computed partial pressures of the chlorides of five metals as $\mathrm{CaCl}_{2}$ is added stepwise to the mixture shown as Test 4 . Data are shown for two $\mathrm{Pb}$ compounds as well as for the dimer of CsCl. (Dimer concentrations have been calculated in all cases in this study but are generaliy not shown in the figures.)

Computations for Test 4 were made at 1100 and $1500 \mathrm{~K}$. Table 9 shows the percent of each of the metals at $1100 \mathrm{~K}$ in the gas phase and in the predominant condensed form, initially, after two additions of $\mathrm{CaCl}_{2}$, and at the end of the additions.

It is seen that the largest change occurs with a small increment of $\mathrm{CaCl}_{2}$. At the second increment, the partial pressures of $\mathrm{Pb}, \mathrm{Zn}$, and $\mathrm{Ni}$ chlorides have increased by a factor of several hundred, for $\mathrm{CS}$ and $\mathrm{Cu}$ about 1.5 and 15 , respectively. The change from 1100 to $1500 \mathrm{~K}$ increased the partial pressures for $\mathrm{Pb}, \mathrm{Cs}, \mathrm{Zn}, \mathrm{Cu}$, and $\mathrm{Ni}$ by factors of $0.9,3,5,320$, and 100 at the second increment, and 1.2, 3, 40,1000, and 1300 at the end of the addition. The smaller change in $\mathrm{Pb}$ volatility, both with respect to $\mathrm{CaCl}_{2}$ addition and with temperature change, probably reflects the higher stability 
TABLE 9. Amounts of Metal Compounds Present During $\mathrm{CaCl}_{2}$ Additions, Test 4 Percent at $1100 \mathrm{~K}$

\begin{tabular}{|c|c|c|c|c|}
\hline $\begin{array}{l}\text { Mols } \mathrm{CaCl}_{2} \text { Added: } \\
\text { Mols Total Ca }\end{array}$ & $\begin{array}{l}0.001 \\
\underline{0.011} \\
\end{array}$ & $\begin{array}{l}0.004 \\
\underline{0.014} \\
\end{array}$ & $\begin{array}{l}0.007 \\
\underline{0.017}\end{array}$ & $\begin{array}{l}0.040 \\
0.050 \\
\end{array}$ \\
\hline Compound & & & & \\
\hline $\begin{array}{l}\mathrm{CsCl}(\mathrm{g}) \\
\mathrm{CsCl} \\
\mathrm{Cs}_{2} \mathrm{SO}_{4} \\
\mathrm{Cs}_{2} \mathrm{Cl}_{2}(\mathrm{~g})\end{array}$ & $\begin{array}{l}6.7 \\
49 \\
41.1 \\
3.3\end{array}$ & $\begin{array}{l}8.0 \\
73 \\
14 \\
5.0\end{array}$ & $\begin{array}{l}8.0 \\
86 \\
1.1 \\
4.9\end{array}$ & $\begin{array}{l}4.0 \\
95 \\
0 \\
1\end{array}$ \\
\hline $\begin{array}{l}\mathrm{CaCl}_{2}(\mathrm{~g}) \\
\mathrm{CaCl}_{2} \\
\mathrm{CaSO}_{4} \\
\mathrm{CaO}\end{array}$ & $\begin{array}{l}3.3-07 \\
1.6-02 \\
53.1 \\
46.5\end{array}$ & $\begin{array}{l}3.0-06 \\
1.0-01 \\
61.5 \\
38.4\end{array}$ & $\begin{array}{l}1.9-05 \\
1.2 \\
58.2 \\
40.5\end{array}$ & $\begin{array}{l}3.0-04 \\
46.2 \\
21.0 \\
32.8\end{array}$ \\
\hline $\begin{array}{l}\mathrm{NiCl}_{2}(\mathrm{~g}) \\
\mathrm{NiCl}_{2} \\
\mathrm{NiSO}_{4} \\
\mathrm{NiO}_{4}\end{array}$ & $\begin{array}{l}8-07 \\
2.8-07 \\
1.6-05 \\
100\end{array}$ & $\begin{array}{l}6-06 \\
2.1-06 \\
2.5-04 \\
100\end{array}$ & $\begin{array}{l}6-05 \\
2.8-5 \\
2.0-05 \\
100\end{array}$ & $\begin{array}{l}1.3-03 \\
1.2-03 \\
9.0-06 \\
100\end{array}$ \\
\hline $\begin{array}{l}\mathrm{CuCl}(\mathrm{g}) \\
\mathrm{CuCl} \\
\mathrm{Cu}_{3} \mathrm{Cl}_{3}(\mathrm{~g}) \\
\mathrm{CuCl}_{2} \\
\mathrm{CuSO}_{4} \\
\mathrm{CuO} \\
\mathrm{Cu}_{2} \mathrm{O}\end{array}$ & $\begin{array}{l}6.0-04 \\
1.5 \\
1.5-07 \\
5.1-07 \\
2.0-07 \\
93.4 \\
5.2\end{array}$ & $\begin{array}{l}1.4-03 \\
4.4 \\
2.0-06 \\
3.7-06 \\
2.7-07 \\
90.1 \\
4.9\end{array}$ & $\begin{array}{l}4.3-03 \\
15.4 \\
5.4-05 \\
4.3-05 \\
2.2-07 \\
80.7 \\
4.0\end{array}$ & $\begin{array}{l}8.7-03 \\
64.4 \\
4.5-04 \\
8.3-04 \\
3.9-08 \\
34.1 \\
1.7\end{array}$ \\
\hline $\begin{array}{l}\mathrm{ZnCl}_{2}(\mathrm{~g}) \\
\mathrm{ZnCl}_{2} \\
\mathrm{ZnSO}_{4} \\
\mathrm{ZnO}\end{array}$ & $\begin{array}{l}3.8-04 \\
2.7-06 \\
1.1-06 \\
100\end{array}$ & $\begin{array}{l}2.3-03 \\
2.0-05 \\
1.5-06 \\
100\end{array}$ & $\begin{array}{l}2.6-02 \\
2.7-04 \\
1.4-06 \\
99.9\end{array}$ & $\begin{array}{l}0.56 \\
1.2-02 \\
5.8-07 \\
99.4\end{array}$ \\
\hline $\begin{array}{l}\mathrm{PbCl}_{2}(\mathrm{~g}) \\
\mathrm{PbCl}(\mathrm{g}) \\
\mathrm{PbCl}_{2} \\
\mathrm{PbSO}_{4} \\
\mathrm{PbO} \\
\mathrm{PbO}_{2}\end{array}$ & $\begin{array}{l}0.13 \\
1.8-03 \\
1.5-02 \\
1.4-02 \\
99.7 \\
0.15\end{array}$ & $\begin{array}{l}0.76 \\
4.3-03 \\
0.11 \\
1.9-02 \\
99.0 \\
0.15\end{array}$ & $\begin{array}{l}7.1 \\
1.3-02 \\
1.3 \\
1.6-02 \\
91.6 \\
0.1 .4\end{array}$ & $\begin{array}{l}53 \\
2.0-02 \\
19 \\
2.0-03 \\
28 \\
4.3-02\end{array}$ \\
\hline
\end{tabular}


of $\mathrm{PbSO}_{4}$ as compared with the sulfates of $\mathrm{Cu}, \mathrm{Ni}$, and $\mathrm{Zn}$. Figures $10 \mathrm{c}, 10 \mathrm{~d}$, $10 \mathrm{e}$, and $10 \mathrm{f}$ show major components of the condensed phases.

There are two effects to be noted; in addition to providing chloride, the calcium in $\mathrm{CaCl}_{2}$ is also effectively complexing the sulfate.

Examination of the material balances indicates several interesting points: 1) essentially all of the chloride as metal halides in the vapor is in the form of $\mathrm{CsCl}, \mathrm{Cs}_{2} \mathrm{Cl}_{2}$, and $\mathrm{PbCl}_{2}$ gas; 2) less than $1 \mathrm{E}-04 \%$ of the $\mathrm{NiO}$ has reacted and only $0.03 \%$ of the $\mathrm{ZnO}$ at the second addition point $\left(\mathrm{CaCl}_{2}=0.007 \mathrm{mols}\right)$.

The description of the condensed phases is difficult since the mutual solubilities are largely unknown. At $1500 \mathrm{~K}$, available phase diagrams (Levin et a1. 1964) indicate that there is likely just one phase (1iquid) for most of the tests considered here. At $1000 \mathrm{~K}$ the description is more difficult. The absolute values of the gas pressures are a function of the condensed phase activities, in turn a function of the phase designations. However, various computation tests indicated that computed gas concentrations relative to each other were not too sensitive to the condensed-phase designations. Tests that produced singularities, concentrations dropping precipitousiy to E-36, were assumed to have incorrectly specified phases. Typical components of Timited solubility may be $\mathrm{CaO}$ and $\mathrm{ZrO}_{2}$. Activity coefficients of unity were used throughout this work.

The model assumes Raoult's law. Thus, since activity coefficients of unity were used for the condensed phase, it is not surprising that

$$
\mathrm{X}_{\mathrm{MX}_{2}}(g)=\mathrm{X}_{\mathrm{MX}_{2}}(1) * \mathrm{P}_{\mathrm{MX}_{2}}^{0},
$$

where $X$ is the mol fraction in the condensed phase and $P_{M X_{2}}^{0}$ is the vapor pressure for the pure compounds, as in Table 3. Mol per cent in each phase is calculated by the HSC program. 
Test 5 is a temperature study of eight metals, each at the same concentration, under typical incinerator conditions, e.g., as in Table 2. A total of 74 compounds were included in the calculation. Pertinent data as a function of temperature from 700 to $1700 \mathrm{~K}$ are plotted in Figures $11 \mathrm{a}$ through $11 \mathrm{~g}$.

$\mathrm{NO}_{x}$ is initially destroyed, but a small amount is present at $1600 \mathrm{~K}$. About $2 / 3$ of the $\mathrm{HF}$ and $2 / 3$ of the $\mathrm{HCl}$ are used initially, but by $1600 \mathrm{~K}$ the metal fluorides have largely disappeared and $90 \%$ of the HF gas remains. About $85 \%$ of the chloride is as metal chlorides at $1600 \mathrm{~K}$. The $\mathrm{SO}_{2}-\mathrm{SO}_{3}$ is consumed at the lower temperatures, but in turn the sulfates formed have 1argely decomposed by $1600 \mathrm{~K}$, and most of the sulfur is present as $\mathrm{SO}_{2}$.

The volatility order of the metal halides changes with temperature due to the changing stability of the several condensed-phase compounds. The computed compositions are shown in Figures 11c through 11g. It is interesting that very high temperatures, greater than $1500 \mathrm{~K}$, appear to actualiy reduce the metal chlorides in the vapor, except for Group I elements. Again, the relative volatilities are not in the same order as vapor pressures of pure compounds or the free energies of formation of the individual chlorides, sulfates, oxides, etc. The relation is complex and changes with temperature.

The significance of $\mathrm{HCl}$ has been noted throughout these studies, and the likely introduction of variable amounts of chlorides introduced in incinerator feeds emphasizes its importance. Test 6 studies the effect of changing the $\mathrm{HCl}$ concentration for 10 metals significant in incinerator partitioning. The $\mathrm{HCl}$ was varied from $2.0 \mathrm{E}-04$ to $3.8 \mathrm{E}-02 \mathrm{mols}$. The gas composition for metals showing amounts greater than 1E-08 mols are plotted in Figures $12 \mathrm{a}$ and $12 \mathrm{~b}$. The temperature is $1500 \mathrm{~K}$. These data illustrate typical volatility trends and, along with data from Test 7 , are used in a later section to help predict partitioning.

Test 7 is a slightly modified version of Test 6 with Sb, $\mathrm{Zr}$, and $\mathrm{Sr}$ added. The $\mathrm{HCl}$ was increased stepwise as before. Figures 13a and 13b show 
the gas composition at 1000 and $1500 \mathrm{~K}$, while Figures $13 \mathrm{c}$ through $13 \mathrm{f}$ indicate major components in the condensed phase.

At $1000 \mathrm{~K}$, the volatility of $\mathrm{SbCl}_{3}$ falls between that of $\mathrm{CoCl}_{2}$ and $\mathrm{CoCl}_{3}$. At $1500 \mathrm{~K}, \mathrm{Sb}_{4} \mathrm{O}_{6}$ is the major gaseous species and represents about $10 \%$ of the total $\mathrm{Sb} .{ }^{(a)}$ The gaseous antimony chlorides increase in concentration by many orders of magnitude as the $\mathrm{HCl}$ is increased from 0.01 to 0.05 mols.

Neither $\mathrm{Zr}$ nor $\mathrm{Sr}$ show marked volatility in this mixture, although $0.3 \%$ of the $\mathrm{Sr}$ is present as $\mathrm{SrCl}_{2}(\mathrm{~g})$ when $1500 \mathrm{~K}$ is reached.

These calculations based on the conditions of Table 9 support earlier conclusions that acidity is of prime importance and that sulfate, calcium, and sodium, for example, could play important roles in controlling volatility of the halides of other metals. Unfortunately, the database does not presently contain sufficient information to permit similar calculations to be performed for phosphates. Available data show that $\mathrm{Ca}_{2} \mathrm{P}_{2} \mathrm{O}_{7}$ and $\mathrm{CaHPO}_{4}$ are the most stable Ca compounds. For $\mathrm{Na}$ it is $\mathrm{NaPO}_{3}$ followed by $\mathrm{Na}_{4} \mathrm{P}_{2} \mathrm{O}_{7}$. But the sulfates of both metals seem to be somewhat more stable than the phosphates. For example, Barin (1989) gives data for zinc phosphate, and for the reaction

$$
3 \mathrm{ZnSO}_{4}+\mathrm{Ca}_{3}\left(\mathrm{PO}_{4}\right)_{2}=2 \mathrm{CaSO}_{4}+\mathrm{Zn}_{3}\left(\mathrm{PO}_{4}\right)_{2}
$$

the free-energy change is $-135 \mathrm{~kJ}$ at $1000 \mathrm{~K}$ and about $-67 \mathrm{~kJ}$ at $1500 \mathrm{~K}$.

In addition to the elements considered in these calculations, several other elements could play a role in retention of metals in the furnace slag. These include $\mathrm{Si}, \mathrm{Ti}, \mathrm{Zr}$, and $\mathrm{AT}$ as mentioned in Section 2.1. The present discussion with its emphasis on chloride volatility treats only a portion of a very complex chemical system.

(a) Barin references work edited by G1ushkov, which gives free energy values making $S b 0(g)$ the major high-temperature species. The original work has not been found. 


\section{PARTITIONING OF THE ELEMENTS}

Based on the above considerations, Table 10 lists the Table 1 elements and the compounds most likely to exist at 1000 to $1300 \mathrm{~K}$. The conditions are the gas composition of Table 2, with the assumption that equilibrium is reached.

An estimate of partitioning behavior can be made based on the data presented and the assumptions described. From the foregoing discussion, it is clear that this behavior depends strongly on the relative concentrations of $\mathrm{HCl}, \mathrm{HF}, \mathrm{SO}_{3}, \mathrm{H}_{2} \mathrm{O}, \mathrm{P}_{2} \mathrm{O}_{5}, \mathrm{O}_{2}$, and a few likely abundant metals such as $\mathrm{Ca}$ and $\mathrm{Na}$. Without knowledge of these concentration ratios, such an estimate is little more than a guess. The estimates in Table 11 assume $\mathrm{H}_{2} \mathrm{O}>\mathrm{CO}_{2} \cong \mathrm{O}_{2}$, $\mathrm{HF} \cong \mathrm{HCT}=1.0-2.0 \%, \mathrm{SO}_{\mathrm{X}}>\mathrm{PO}_{\mathrm{X}}$, and consider the water solubilities of the stable compounds. The basic incinerator of Figure 1 is assumed, with the temperature about 1400-1500 K and component efficiencies typical of operations reported in the literature. As noted earlier, the fraction going to the stack can always be reduced by adding additional clean-up options. Because of this uncertain factor, the table includes only the burner ash and the fly ash. In a few cases, e.g., tritium and iodine, losses to the stack may be very large unless special trapping devices are employed. The table also includes a range of values reported in the literature.

For a smaller group of elements, an attempt was made to make a closer estimate of partitioning on the basis of the equilibrium calculations described above and solubilities, assuming a water scrub of the off-gas. The eight elements so estimated, listed in Table 13, represent different regions of the periodic table, and have quite different properties from each other.

Strontium is similar to calcium except that the sulfate is much more stable. The stability of the chloride is somewhat greater, but its vapor pressure is lower than for calcium. Thus, a large change in $\mathrm{Sr}$ release is not expected with increased $\mathrm{HCl}$. Zirconium is different in that the sulfate is 


\section{TABLE 10. Most Likely Compounds in the Oxidizing Incinerator}

\begin{tabular}{|c|c|}
\hline Element & Probable Form \\
\hline $\begin{array}{l}\mathrm{T} \\
\mathrm{Na} \\
\mathrm{Cs}\end{array}$ & $\begin{array}{l}\mathrm{HTO} \\
\mathrm{Na}_{2} \mathrm{SO}_{4}, \mathrm{NaCl}_{1} \\
\mathrm{CsC1}, \mathrm{Cs}_{2} \mathrm{SO}_{4}, \mathrm{CsI}\end{array}$ \\
\hline $\begin{array}{l}\mathrm{Be} \\
\mathrm{Ca} \\
\mathrm{Sr} \\
\mathrm{Ra} \\
\mathrm{V} \\
\mathrm{Cr} \\
\mathrm{Mn} \\
\mathrm{Fe}\end{array}$ & 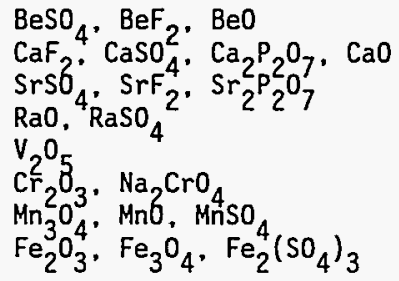 \\
\hline $\begin{array}{l}\mathrm{Co} \\
\mathrm{Ni} \\
\mathrm{Cu} \\
\mathrm{Zn}\end{array}$ & $\begin{array}{l}\mathrm{CoO}, \mathrm{CoSO}_{4} \\
\mathrm{NiO}, \mathrm{NiSO}_{4} \\
\mathrm{Cu}_{2} \mathrm{O}, \mathrm{CuSO}_{4} \\
\mathrm{ZnO}, \mathrm{ZnSO}_{4}\end{array}$ \\
\hline $\begin{array}{l}\mathrm{Y} \\
\mathrm{Zr} \\
\mathrm{Nb} \\
\mathrm{Tc} \\
\mathrm{Ru} \\
\mathrm{Ag} \\
\mathrm{Cd}\end{array}$ & $\begin{array}{l}\mathrm{YF}_{3}, \mathrm{Y}_{2} \mathrm{O}_{3} \\
\mathrm{ZrO}_{2}, \mathrm{ZrF}_{2} \\
\mathrm{Nb}_{2} \mathrm{O}_{5}, \mathrm{TcO}_{3} \\
\mathrm{Tc}_{2} \mathrm{O}_{7}, \mathrm{TuO}_{3} \\
\mathrm{RuO}_{2}, \mathrm{RuO}_{4} \mathrm{SO}_{4}, \mathrm{Ag} \\
\mathrm{AgCT}, \mathrm{Ag}_{2} \mathrm{SO}_{4}, \mathrm{CdSO} 4 \\
\mathrm{CdO}, \mathrm{CSO}_{4}\end{array}$ \\
\hline $\begin{array}{l}\mathrm{Au} \\
\mathrm{Hg}\end{array}$ & $\begin{array}{l}\mathrm{Au} \\
\mathrm{Hg}_{2} \mathrm{Cl}_{2}, \mathrm{HgCl}_{2}\end{array}$ \\
\hline $\begin{array}{l}\text { Ga } \\
\text { In }\end{array}$ & \\
\hline $\begin{array}{l}\mathrm{C} \\
\mathrm{Ge}\end{array}$ & $\begin{array}{l}\mathrm{CO}_{2}, \quad \mathrm{Na}_{2} \mathrm{CO}_{3} \\
\mathrm{GeO}_{2}, \quad \mathrm{GeCl}_{4}\end{array}$ \\
\hline $\begin{array}{l}\mathrm{Sn} \\
\mathrm{Pb} \\
\mathrm{P} \\
\text { As }\end{array}$ & $\begin{array}{l}\mathrm{SnO}_{2} \\
\mathrm{PbO}_{2}^{2}, \quad \mathrm{PbO} \\
\mathrm{P}_{4} \mathrm{O}_{10}, \mathrm{H}_{3} \mathrm{PO}_{4} \\
\mathrm{As}_{2} \mathrm{O}_{3}, \mathrm{As}_{2} \mathrm{O}_{5}\end{array}$ \\
\hline $\mathrm{Sb}$ & $\mathrm{Sb}_{4} \mathrm{O}_{6}, \mathrm{SbCl}_{3}, \mathrm{SbO}(\mathrm{g})(?)$ \\
\hline $\mathrm{Bi}$ & $\mathrm{Bi}_{2} \mathrm{O}_{3}, \mathrm{BiOCl}, \mathrm{BiCl}_{3}$ \\
\hline $\begin{array}{l}\mathrm{S} \\
\mathrm{Se} \\
\mathrm{Te}\end{array}$ & $\begin{array}{l}\mathrm{SO}_{2}, \mathrm{SO}_{3} \cdot \mathrm{H}_{2} \mathrm{SO}_{4} \\
\mathrm{SeO}_{2} \\
\mathrm{TeO}_{2}\end{array}$ \\
\hline $\begin{array}{l}\mathrm{I} \\
\mathrm{Ce} \\
\mathrm{Pm} \\
\mathrm{Eu}\end{array}$ & $\begin{array}{l}\mathrm{I}_{2}, \mathrm{ICl}, \mathrm{CH}_{3} \mathrm{I}, \mathrm{CsI} \\
\mathrm{Ce}_{2} \mathrm{O}_{3} \\
\mathrm{Pm}_{2} \mathrm{O}_{3} \\
\mathrm{Eu}_{2}^{2} \mathrm{O}_{3}\end{array}$ \\
\hline $\begin{array}{l}\text { Th } \\
\mathrm{U} \\
\mathrm{Np} \\
\mathrm{Pu} \\
\text { Ann }\end{array}$ & $\begin{array}{l}\mathrm{ThO}_{2} \\
\mathrm{UO}_{3}, \mathrm{U}_{3} \mathrm{O}_{8} \\
\mathrm{NpO}_{2} \\
\mathrm{PuO}_{2}^{2} \\
\mathrm{Am}_{2} \mathrm{O}_{3}\end{array}$ \\
\hline
\end{tabular}

Some TX ( $X=$ halogen $)$

$\mathrm{Na}_{2} \mathrm{CO}_{3}$ if system alkaline

$\mathrm{Cs}_{2}^{2} \mathrm{CO}_{3}^{3}$ if system alkaline

$\mathrm{CaCO}_{3}$ stable to $\sim 1200 \mathrm{~K}$ if acids absent.

$\mathrm{SrZrO}_{3}$ if $\mathrm{S}$ absent

metal vanadates, e.g., $\mathrm{NaVO}_{3}$. $\mathrm{VOCl}_{3}$ possible at high $\mathrm{HCl}$ conc

$\mathrm{CrO}_{2} \mathrm{Cl}$, very volatile but requires $(\mathrm{HCl}) \gg\left(\mathrm{H}_{2} \mathrm{O}\right)$

$\mathrm{MnCF}_{2} \mathrm{bp}=1450 \mathrm{~K}$. MnF has equal stability. $\mathrm{MnSiO}_{3}$ possible

$\mathrm{FeCl}_{3}^{2} \mathrm{bp}=603 \mathrm{~K}$. $\mathrm{FeCl}_{2}^{2}(\mathrm{~g})$ more stable at $\mathrm{T}>1200^{3} \mathrm{~K}$. Silicates

also possible.

$\mathrm{CoCl}$, bp=1342 K, phosphate also

$\mathrm{NiCl}{ }_{2}^{2} b p=1303 \mathrm{~K}$, phosphate also

CuCl ${ }^{2}$ bp=(1485) K. (vapor $\left.\mathrm{Cu}_{3} \mathrm{Cl}_{3}\right), \mathrm{CuCl}_{2}$ unstable

$\mathrm{ZnCl}_{2} \mathrm{bp}=1000 \mathrm{~K}$

$\mathrm{YF}_{3}$ most stable compound

NbOCl possibly stable, sublimes at 550K

$\mathrm{RuO}_{4}$ readily formed, $b p=333 \mathrm{~K}$. $\mathrm{RuO}_{2}$ volatile at about $1000 \mathrm{~K}$

$\mathrm{CdCl}_{2}$ bp $=1236 \mathrm{~K}$

$\mathrm{AuCl}_{3}$ if high conc $\mathrm{HCl}$

Some $\mathrm{HgSO}_{4}$. Some $\mathrm{Hg}$ at high temp

Halides not stable towards $\mathrm{H}_{2} \mathrm{O}$

Possibly $\mathrm{InF}_{3}$

Hydrocarbon traces

$\mathrm{GeCl}_{4} \mathrm{bp}=356 \mathrm{~K}$, stable at low temperature, hydrolyze at high

temperature. Ge0 slightly vol.

$\mathrm{SnCl}_{4} b p=388 \mathrm{~K}$. $\mathrm{SnCl}_{2} b p=925$ Requires high $\mathrm{HCl}$ conc.

$\mathrm{PbCl}_{2}^{4} \mathrm{bp}=1223 \mathrm{~K}$

Also as metal phosphates

$\mathrm{As}_{2} \mathrm{O}_{5}$ not stable at high temp. $\mathrm{As}_{2} \mathrm{O}_{3} \mathrm{bp}=732 \mathrm{~K}$. May also exist as arsenates.

Some $\mathrm{SbCl}_{3}$ if $\mathrm{HCl}=0.01 \mathrm{~atm}$

Both $\mathrm{BiCl}_{3}$ and $\mathrm{BiOCl}$ volatile and moderately stable

Also as metal sulfates, especially $\mathrm{Na}_{2} \mathrm{SO}_{4}$

Sublimes $602 \mathrm{~K}$

$\mathbf{P}=0.1$ torr at $1000 \mathrm{~K}, 50$ torr at $1300 \mathrm{~K}$

Some HI 
TABLE 11. Estimated Partition Values

\begin{tabular}{|c|c|c|c|c|}
\hline \multirow[t]{2}{*}{ - Element } & \multicolumn{2}{|c|}{ Ash } & \multicolumn{2}{|c|}{ Fly Ash } \\
\hline & $\underline{\text { Lit }}$ & Est & Lit & Est \\
\hline $\begin{array}{l}\mathrm{H}(\mathrm{T}) \\
\mathrm{Na} \\
\mathrm{Cs}\end{array}$ & $\begin{array}{l}0 \\
60-90 \\
60-90\end{array}$ & $\begin{array}{l}0 \\
90 \\
85\end{array}$ & $\begin{array}{l}0 \\
30-50 \\
30-50\end{array}$ & $\begin{array}{l}10 \\
10 \\
15\end{array}$ \\
\hline $\begin{array}{l}\mathrm{Be} \\
\mathrm{Sr} \\
\mathrm{Ra} \\
\mathrm{V} \\
\mathrm{Cr} \\
\mathrm{Mn} \\
\mathrm{Fe} \\
\mathrm{Co} \\
\mathrm{Ni} \\
\mathrm{Cu} \\
\mathrm{Zn}\end{array}$ & $\begin{array}{l}90-99 \\
45-95 \\
80-95 \\
90-99 \\
80-100 \\
50-99 \\
60-98 \\
70-98 \\
40-100 \\
50-99 \\
30-70\end{array}$ & $\begin{array}{l}90 \\
95 \\
90 \\
90 \\
65 \\
65 \\
55 \\
60 \\
60 \\
55 \\
50\end{array}$ & $\begin{array}{l}2-10 \\
2-20 \\
- \\
10 \\
70 \\
25-45 \\
3-20 \\
12-20 \\
10-20 \\
20-60 \\
20-60\end{array}$ & $\begin{array}{l}10 \\
5 \\
10 \\
10 \\
34 \\
34 \\
44 \\
39 \\
9 \\
45 \\
49\end{array}$ \\
\hline $\begin{array}{l}\mathrm{Y} \\
\mathrm{Zr} \\
\mathrm{Nb} \\
\mathrm{Tc} \\
\mathrm{Ru} \\
\mathrm{Ag} \\
\mathrm{Cd}\end{array}$ & $\begin{array}{l}60-95 \\
60-95 \\
65-75 \\
10-95 \\
70-90 \\
30-99 \\
30-90\end{array}$ & $\begin{array}{l}95 \\
95 \\
95 \\
40 \\
40 \\
80 \\
40\end{array}$ & $\begin{array}{l}40-60 \\
40-60 \\
- \\
- \\
5-25 \\
15-45 \\
20-40\end{array}$ & $\begin{array}{l}5 \\
5 \\
5 \\
50 \\
59 \\
20 \\
58\end{array}$ \\
\hline $\begin{array}{l}\mathrm{Au} \\
\mathrm{Hg}\end{array}$ & $\begin{array}{l}70-80 \\
1-25\end{array}$ & $\begin{array}{l}80 \\
5\end{array}$ & $\overline{30-90}$ & $\begin{array}{l}19 \\
90\end{array}$ \\
\hline $\begin{array}{l}\text { Ga } \\
\text { In }\end{array}$ & - & $\begin{array}{l}90 \\
98\end{array}$ & - & $\begin{array}{l}10 \\
2\end{array}$ \\
\hline $\begin{array}{l}\mathrm{C} \\
\mathrm{Ge} \\
\mathrm{Sn} \\
\mathrm{Pb} \\
\mathrm{P} \\
\mathrm{As} \\
\mathrm{Sb} \\
\mathrm{Bi}\end{array}$ & $\begin{array}{l}0.2-1 \\
- \\
30-95 \\
30-97 \\
95 \\
70-99 \\
10-80 \\
10-75\end{array}$ & $\begin{array}{l}0-10 \\
50 \\
98 \\
40 \\
85 \\
50 \\
55 \\
30\end{array}$ & $\begin{array}{l}- \\
- \\
- \\
40-80 \\
- \\
5-25 \\
20-80 \\
15-60\end{array}$ & $\begin{array}{l}2 \\
50 \\
2 \\
60 \\
13 \\
50 \\
44 \\
70\end{array}$ \\
\hline $\begin{array}{l}\mathrm{S} \\
\mathrm{Se} \\
\mathrm{Br} \\
\mathrm{Te} \\
\mathrm{I} \\
\mathrm{Cl}\end{array}$ & $\begin{array}{l}72 \\
1-20 \\
- \\
50 \\
<1 \\
\sim 1\end{array}$ & $\begin{array}{l}30 \\
10 \\
10 \\
50 \\
2 \\
10\end{array}$ & $\begin{array}{l}- \\
- \\
- \\
-\end{array}$ & $\begin{array}{l}65 \\
80 \\
90 \\
49 \\
68 \\
89\end{array}$ \\
\hline $\begin{array}{l}\mathrm{Ce} \\
\mathrm{Pm} \\
\mathrm{Sm} \\
\mathrm{Eu}\end{array}$ & $\begin{array}{l}75-95 \\
90-95 \\
45-95 \\
50-95\end{array}$ & $\begin{array}{l}95 \\
95 \\
95 \\
95\end{array}$ & $\begin{array}{l}30-60 \\
- \\
30-60 \\
30-60\end{array}$ & $\begin{array}{l}5 \\
5 \\
5 \\
5\end{array}$ \\
\hline $\begin{array}{l}\text { Th } \\
U \\
\mathrm{~Np} \\
\mathrm{Pu} \\
\mathrm{Am}\end{array}$ & $\begin{array}{l}40-90 \\
65-100 \\
- \\
85-95 \\
-\end{array}$ & $\begin{array}{l}98 \\
98 \\
98 \\
98 \\
98\end{array}$ & $\begin{array}{l}20-50 \\
1-35 \\
- \\
- \\
-\end{array}$ & $\begin{array}{l}2 \\
2 \\
2 \\
2 \\
2\end{array}$ \\
\hline
\end{tabular}


TABLE 12. Estimated Partition of Selected Nuclides Temperature $1500 \mathrm{~K}$

\begin{tabular}{|c|c|c|c|c|c|c|}
\hline \multirow{2}{*}{$\mathrm{HCl}$ : } & \multicolumn{2}{|c|}{ Slag, \% } & \multicolumn{2}{|c|}{ Fly Ash, \% } & \multicolumn{2}{|c|}{ Stack, \% } \\
\hline & 0.005 & 0.05 & 0.005 & 0.05 & 0.005 & 0.05 \\
\hline $\mathrm{Cs}$ & 70 & 4 & 29 & 94 & $<1$ & 2 \\
\hline Sr & 96 & 95 & 4 & 5 & $E-04$ & $E-04$ \\
\hline $\mathrm{Zr}$ & 97 & 96 & 3 & 4 & $E-04$ & $E-04$ \\
\hline Co & $>99$ & 97 & $E-03$ & 2 & $E-04$ & 0.4 \\
\hline $\mathrm{Zn}$ & $>99$ & 60 & $E-03$ & 36 & $E-04$ & 4 \\
\hline $\mathrm{Sb}$ & $>99$ & 97 & $E-02$ & 2 & $E-03$ & 0.2 \\
\hline$I$ & 2 & 3 & 70 & 75 & 28 & 22 \\
\hline U & 98 & 96 & 2 & 4 & $<1$ & $\ll 1$ \\
\hline
\end{tabular}

not very stable, but the oxide is so stable with respect to the chloride that little $\mathrm{ZrCl}_{4}(\mathrm{~g})$ should form. The conversion curve lies close to that of $\mathrm{Ge}$ in Figure 3. Formation of $\mathrm{ZrF}_{4}(\mathrm{~g})$ is only slightly more favorable, and in the presence of a small amount of water it appears impossible to vaporize $\mathrm{Zr}$ as the halide. Uranium should behave the same way.

Iodine is completely different. There may be little change with $\mathrm{HCl}$ concentration; an increased $\mathrm{Cl}$ level could increase the $\mathrm{ICl}$ concentration, which may be easier to remove with a water scrub than is $I_{2}$. The remaining elements in Table 12, Cs, Co, $\mathrm{Zn}$, and Sb, by contrast, are greatly affected by $\mathrm{HCl}$ concentration, as seen in Figures $13 \mathrm{a}$ and $13 \mathrm{~b}$.

Table 12 lists the resulting estimated partitions for two $\mathrm{HCl}$ levels. The temperature is $1500 \mathrm{~K}$. The estimated changes in element percentages as the $\mathrm{HCl}$ is increased are based on the calculated changing compositions, primarily the metal chloride concentration. The uncertainties are large. Since it is assumed that HEPA filters are not present, particulate losses depend on the efficiency of the other components of the off-gas cleaning system, and the absolute numbers have limited significance.

Many questions remain. Predominant among them are kinetics, which determine whether favorable chemical reactions can actually take place, whether volatile species are in equilibrium with a condensed phase, and what 
role diffusion plays in solids and liquids. It can be imagined that chemistry in micro dimensions in a combustion chamber where neither equilibrium nor steady state may exist can be significantly different from an ideal uniform system. Temperatures at the surface of a burning particle may exceed the buik temperature. Metals returning to the solid state from the gas tend to form extremely small particles or "fumes" and become more difficult to trap. It is also expected that gaseous products (metals or metal salts) may condense or adsorb on particulates in the rapidly moving gas stream and reach a lowertemperature regime before equilibrium can be reached. Temperature may be the most important variable in the kinetics; as it is in equilibria.

As an example of the temperature effect on volatility, a change of $100^{\circ} \mathrm{C}$ at about $1200 \mathrm{~K}$ will change the vapor pressure of $\mathrm{CsCl}$ by a factor of about 10, and of $\mathrm{Pb}$ by over 20 . Thus, several metals, metal halides, and hydroxides can change from having negligible vapor pressures to becoming quite volatile over the range of temperatures that have been used in incinerator operation.

At about 800 to $1100 \mathrm{~K}$, sulfate ion could have an effect of reducing the volatility of some metals such as halides by. several factors of ten. But, at $1300 \mathrm{~K}$ much of the protection may be gone. Temperature is also important in defining the nature of the slag, e.g., clinker formation, and as noted above is also the most important parameter in reaction rates. The temperature factor is graphically illustrated in the modeling calculations. 


\section{OTHER INC INERATOR MODIFICATIONS}

\section{THE CONTROLLED AIR INCINERATOR}

The controlled air or limited oxygen incinerator has at least three major differences, a temperature lower by perhaps 200 to $300^{\circ} \mathrm{C}$, a 1 ower oxidation potential in the burner, and a lower gas velocity. The effect of the first is obvious. The effect of the second is more subtle. Possible changes would be lower oxidation states of some of the metals and an increase in the stability of the chlorides relative to the oxides. The effect of the third is one of the arguments for the controlled air operation, i.e., reduction of the flow of particulate matter from the combustion zone due to the reduced gas velocity, and the overall decreased load on the air pollution control equipment.

The chemistry of the limited oxidation incinerator is not discussed in this paper. Some of the thermodynamic discussion above would need revision for a reducing system. However, the controlled air burner is normally followed by a second-stage oxidizing system.

\section{THE CEMENT KILN}

The use of cement kilns for even low-level RW will probably not be accepted, but the kilns can tolerate many hazardous wastes. Some of the characteristics - the higher temperature and the alkaline environment. - were mentioned in the introduction. The chemistry of the cement kiln may be better understood since it is governed by a only few major feed components. Thus the fate of minor nuclides in the feed materials should be more consistent than for a RW incinerator. The behavior of several metals and other additives was surveyed by Mantus (1992). It is suggested that the behavior of lowconcentration metals in the cement kiln is worthy of further detailed study. 


\section{EFFICIENCY OF AQUEOUS SCRUBS}

Improving the efficiency of aqueous scrubs is a problem with all gas cleaning systems. Removing a very soluble gas like $\mathrm{HCl}$ is relatively easy; iodine provides a more difficult task (Brown et al. 1983; Bunger and Scheele 1991). Particulate matter may be even more difficult to remove, depending on the particle size. Fortunately, most metal chlorides and bromides are at least moderately soluble in water. This is less true for the fluorides. However, a wel1-designed, combined mechanical-aqueous scrub system seems to offer the best hope of keeping most undesirable effluents from the exhaust stack.

\section{DELIBERATE ADDITIONS TO THE FEED}

It appears that a knowledge of the chemical composition of the incinerator feed is desireable to manage the off-gas behavior effectively. It should be possible to greatly influence metal partitioning by controlling the feed composition. Elements such as P, S, AT, Si, Ca, Na, and the halogens can change the volatility of other metals as well as the physical nature of the solids removed. Specific compounds could be introduced; for example, $\mathrm{NaNO}_{3}$ or $\mathrm{Na}_{2} \mathrm{CO}_{3}$ would raise the alkalinity of the condensed phase, and the sodium also preferentially ties up the chlorine, thus reducing volatility of many metals. Adding sulfates would reduce low-temperature volatility since the sulfates of most of the metals of concern are more stable than the chlorides up to about $1000 \mathrm{~K}$. By contrast, $\mathrm{CaCl}_{2}$ becomes a chlorinating agent and could be employed if desired to deliberately increase volatility of several metals. Calcium, added as lime, would also raise the melting point of the ash or slag.

Other elements may form complexes that help retain metals in the slag. These include the conventional glass-formers normally present in the feed, such as silicates from glass waste as well as from paper, borates from glass and decontaminating agents, and phosphorous from organic solvents. Titanium will be introduced from paper waste. 


\section{CONCLUSION}

The chemical properties of 50 nuclides have been considered and thermodynamic equilibria calculated at elevated temperatures to predict the chemical species present in an oxidizing incinerator. Combined with the physical properties of these species, the data heip predict their likely-retention in the ash or slag from the burner, their escape from the burner to be trapped in the off-gas treatment system as fly ash, or their possible release to the atmosphere. Particular emphasis was given to the formation and volatility of metal halides and the influence of other elements on this volatility. In addition to consideration of individual element properties, several calculations were made on multicomponent systems using a computer mode1. These were used to predict relative concentrations of different chemical species for different feed compositions, and as a function of temperature. These findings support predictions made with calculations for individual elements and show promise for more detailed computation.

Using the data developed, an estimate is then made as to how partitioning of these nuclides might be affected for a general case, and for selected elements, as a function of $\mathrm{HCl}$ concentration.

It must be emphasized that incineration is a complex phenomenon; chemical equilibrium is not necessarily achieved, and kinetics not only of chemical reaction but also involving adsorption and diffusion will be important. Thus, the numerical data derived from the calculations presented here should be viewed as guides, not as absolute quantities. In spite of these uncertainties, it is suggested that deliberate control of the types and amounts of various compounds entering the incinerator can greatly influence partitioning and thus affect potential releases and the management of incinerator wastes. 


\section{REFERENCES}

Bailar, J. C., Jr. et a1. 1973. Comprehensive Inorganic Chemistry. Pergamon Press, New York.

Barin, 0. 1989. Thermochemical Data of Pure Substances: VCH, Weinheim, Germany.

Brown, A. R., J. D. Christian, and T. R. Thomas. 1983. Airborne Radionuclide Waste Management Reference Document. ENIC0-1133, Exxon Nuclear Idaho Company, Inc., Idhao Falls, Idaho.

Bunger, L. L., and R. d. Scheele. 1991. HWVP Iodine Trap Evlauation. PNL-7851, Pacific Northwest Laboratory, Richland, Washington.

Chao, C. C. 1988. "Assessment of A7ternative Flue Gas Treatment for Hazardous Waste Incineration." In Proceedings, The International Conference on Incineration of Hazardous, Radioactive and Mixed Wastes, San Francisco, California.

Christian, J. D. 1990. Behavior and Control of Ruthenium During Operation of the New Waste Calcining Facility at the Idaho Chemical Processing P1ant. WINC0-11640, Westinghouse Idaho Nuclear Co. Inc., Idaho Fal1s, Idaho.

Dean, J. A. 1992. Lange's Handbook of Chemistry. McGraw-Hi11, Inc., New York.

Emery, R. J., and J. E. Watson. 1990. "Retention and Subsequent Release of Radioactivity from the Incineration of Wastes Containing Microspheres." Health Phys. 59:911-914.

Ephraigm, F. 1953. Inorganic Chemistry. Nordeman Publishing Co., New York.

Fernandez, M. A., et a1. 1992. "Behavior of Heavy Meta7s in the Combustion Gases of Urban Waste Incinerators." Environ. Sci. Technol. 26(5):1040-1047.

Glassner, A. 1958. The Thermochemical Properties of the 0xides, Fluorides, and Chlorides to $2500 \mathrm{~K}$. ANL-5750, U.S. Argonne National Laboratory, University of Chicago. Chicago, Illinois.

Greenberg, R. R., W. H. Zoller, and G. E. Gordon. 1978. "Composition and Size Distributions of Particles Released in Refuse Incineration." Environ. Sci. Technol. 12:566-573. 
Kyle, S., and E. Bellinger. 1988. Radioactivity Partitioning in Incinerators for Miscellaneous Low-Level Wastes. D0E/RW/88069, University of Manchester, Manchester, United Kingdom.

Levin, E. M., C. A. Roberts, and H. F. McMurdie. 1964. Phase Diagrams for Ceramists. American Ceramics Society, Columbus, Ohio.

Mantus, E. K. 1992. Al1 Fired Up--Burning Hazardous Wastes in Cement Kilns. Environmental Toxicology International, Inc., Seattle, Washington.

Oppelt, E. T. 1986. "Hazardous Waste Destruction." Environ. Sci. Technol. $20(4): 312-318$.

Outokumpu Research. 1994. HSC Chemistry for Windows. Outokumpu Research, Fin1 and.

Perkins, B. L. 1976. Incineration Facilities for Treatment of Radioactive Wastes: A Revue. LA-6252, Los Alamos Scientific Laboratory, Los Alamos, New Mexico.

Science Applications International Corporation (SAI Corp). 1991. An Assessment of Thermal Destruction Technologies for Application to Department of Energy Mixed Wastes, Vol 1, Technology Assessment, Vol 2, Technology Data Sheets. D0E/HWP-106-Vol 2, Idaho Fal1s, Idaho.

Sedman, R. M., and J. R. Esparza. 1991. "Evaluation of the Public Health Risks Associated with Semivolatile Metal and Dioxin Emissions from Hazardous Waste Incinerators." Environ. Health Perspect. 94:181-187.

Stern, K. H. 1972. "High Temperature Properties and Decomposition of Inorganic Salts. Part 3, Nitrates and Nitrites of sodium and Potassium." J. Phys. Chem. Ref. Data $1(3): 747$.

Steverson, E. M. 1991. "Provoking a Firestorm: Waste Incineration." Environ. Sci. Technol. 25(11):1808-1814.

Travis, C. C., and S. C: Cook. 1989. Hazardous Waste Incineration and Human Hea7th. CRC Press, Boca Raton, Florida.

Trichon, M., and J. Feldman. 1988. "Metallic Halide Emissions from Fixed and Hazardous Waste: Meeting Regulatory Requirements with New Technology." In Proceedings, International Conference on Incineration of Hazardous Radioactive and Mixed Wastes, San Francisco, California.

U.S. Department of Energy (DOE). 1979. Technology for Commercial Radioactive Waste Management. DOE/ET-0028, Volume 2, Section 4, Washington, D.C. 
U.S. Environmental Protection Agency (EPA). 1991. Radiation and Mixed Waste Incineration. Background Information Document Vol 1. EPA 520/1-91-

I:Technology.

Wagman, D. D., et al. 1982. The NBS Tables of Chemical Thermodynamic Properties, American Chemical Society and American Institute of Physics. J. Phys. Chem. Ref. Data 11(Supp1. 2).

Waterland, L. R., et a1. 1991. "Trace Metal Fate in a Rotary Kiln Incinerator with an Ionizing Wet Scrubber." Waste Management 11:103-109.

Weast, R. C. (ed.). 1978. Handbook of Chemistry and Physics. The Chemical Rubber Co., Cleveland, Ohio. 


\section{DISTRIBUTION}

No. of

Copies

\section{OFFSITE}

2 DOE/Office of Scientific

Technology and Information

W. L. Beck

EESD/ESAP

P.0. Box 117

Oak Ridge, TN 37831-0017

W. D. Bostic

Chemistry Department, K-25 Site

Martin Marietta Energy Systems, Inc.

P.0. Box 2003

Oak Ridge, TN 37830

J. D. Christian

Lockheed Idaho Technologies Co.

Box 1625

Idaho Fal1s, ID 83415-3423

H. T. Peterson, Jr.

Air, Water, and Radiation Division, EH-22

U.S. Department of Energy 1000 Independence Ave., S.W. Washington, DC 20585

\section{Stevens}

Trevino II, EM-331 12800 Midd7ebrook Rd. Germantown, MD 20874
No. of

Copies

T. Tseng

U.S. Department of Energy

EM-36

Trevino II

Washington, DC 20585-0002

G. Vazquez

Air, Water, and Radiation

Division, EH-22

U.S. Department of Energy

1000 Independence Ave., S.W. Washington, DC 20585

A. Wallo III, Director

Air, Water, and Radiation

Division, EH-22

U.S. Department of Energy 1000 Independence Ave., S.W. Washington, DC 20585

\section{ONSITE}

7 Westinghouse Hanford Company

G. S. Barney

T5-12

T. D. Cooper

T5-12

D. R. Dickinson

L5-31

J. L. Perez

T1-98

D. A. Reynolds

R2-11

D. A. Turner

S7 -15

R. K. Welty 
No. of

Copies

42 Pacific Northwest Laboratory
A. L. Aaberg (2)
K3-54
D. A. Baker
K3-54
G. H. Bryan
P7-25
S. A. Bryan
P7 -35
L. L. Burger (10)
P7 -25
J. L. Cox
P8-38
T. H. Dunning
$\mathrm{K} 2-18$
D. J. Hanley
K3-53
R. L. Hill
K3-56
M. F. Jarvis
K6-55
G. A. Jensen
G6-01
B. M. Johnson, Jr.
K1-78
W. E. Kennedy, Jr.
K3-54
D. E. Larson
P7 -63
L. G. Morgan (2)
P7-35
L. R. Pederson
K2-44
K. Rhoads
K3-54
J. L. Ryan
P7-25
R. D. Scheele
P7 -25
L. J. Sealock
$\mathrm{K} 2-10$
J. K. Soldat
K3-54
D. M. Strachan
$\mathrm{K} 2-44$
J. M. Tingey
P7 -25
D. W. Webster
P7 -25
K. D. Wiemers
P7-14
Pubtishing Coordination
Technical Report Files (5) 